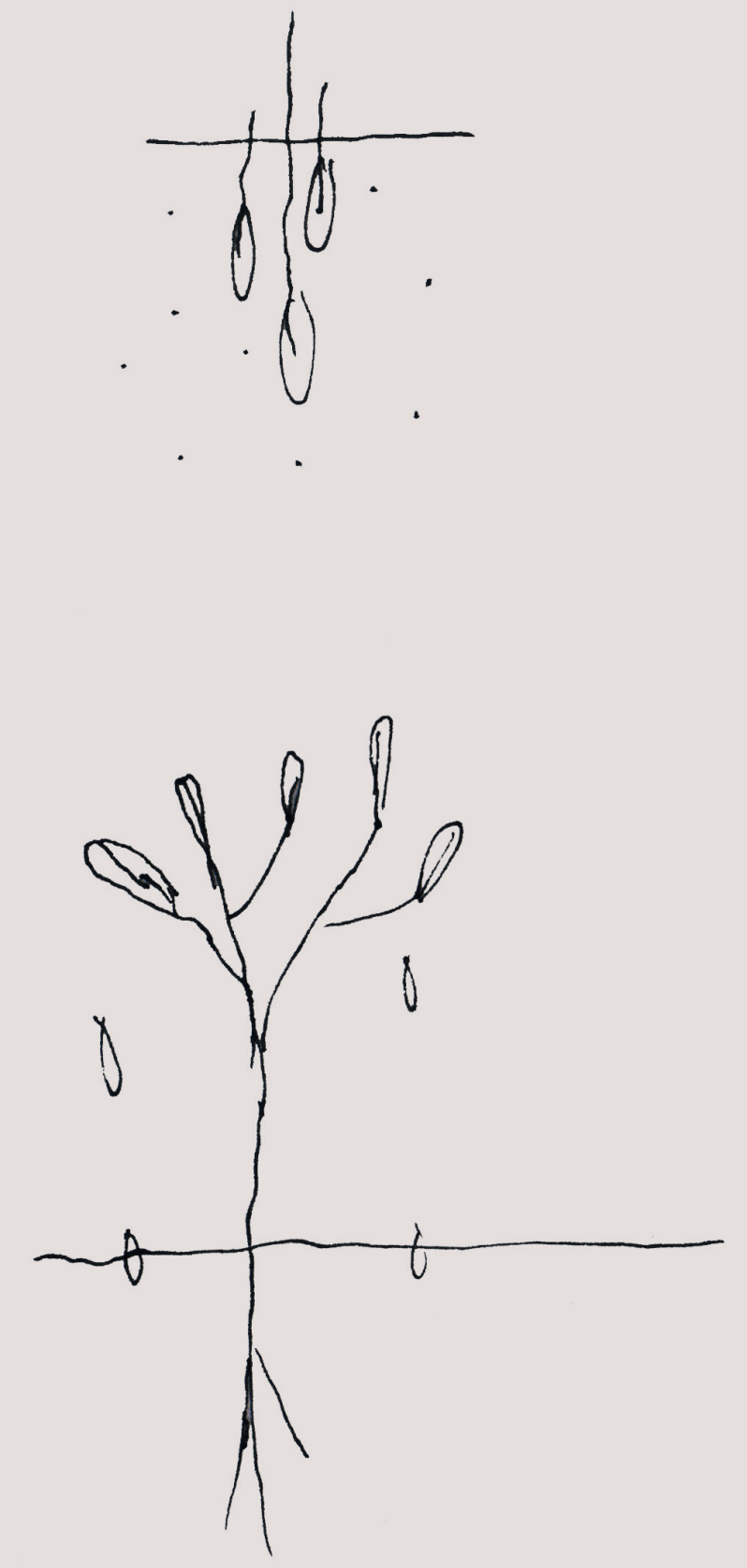

0

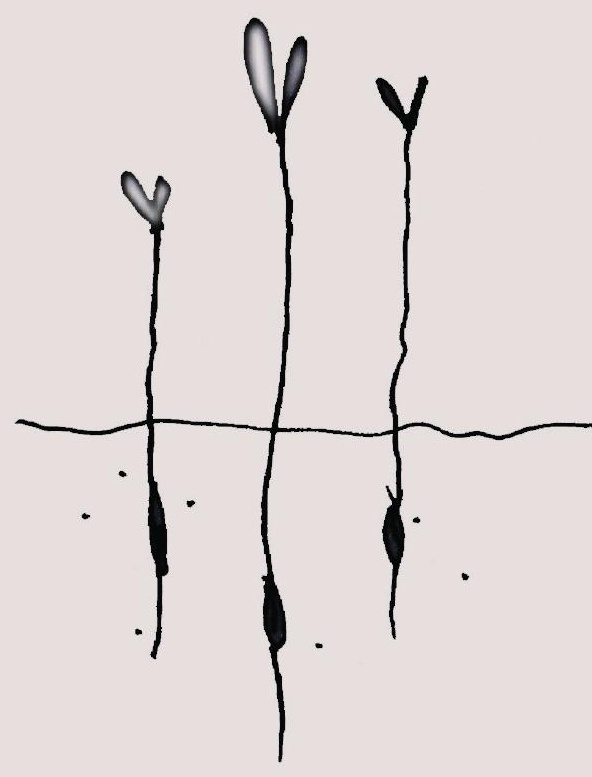

Tafelen over transities

Een analyse van small wins door de Participatie Tafel Regionale Netwerken (PTRN)

M. Pleijte en C.J.A.M. Termeer 



\section{Tafelen over transities}

Een analyse van small wins door de Participatie Tafel Regionale Netwerken (PTRN)

M. Pleijte ${ }^{1}$ en C.J.A.M. Termeer ${ }^{2}$

1 Wageningen Environmental Research

2 Wageningen University

Dit onderzoek is uitgevoerd door Wageningen Environmental Research en Wageningen University in opdracht van en gefinancierd door RVO/DuurzaamDoor

Wageningen Environmental Research

Wageningen, november 2020

Gereviewd door:

Wim de Haas, senior onderzoeker Landscape Governance (Wageningen Environmental Research)

Akkoord voor publicatie:

Wies Vullings, teamleider van team Applied Spatial Research

Rapport 3039

ISSN 1566-7197 
Pleijte, M. en C.J.A.M. Termeer, 2020, 2020. Tafelen over transities; Een analyse van small wins door de Participatie Tafel Regionale Netwerken (PTRN). Wageningen, Wageningen Environmental Research, Rapport 3039. 78 blz.; 3 fig.; 9 tab.; 13 ref.

De Participatie Tafel Regionale Netwerken (PTRN) heeft de afgelopen drie jaar verschillende projecten ondersteund om de transitie naar een duurzame samenleving verder te brengen door middel van nieuwe arrangementen, variërend van gebiedscoöperaties tot voedselraden. Dit rapport analyseert in hoeverre de small wins-aanpak kan helpen om de resultaten van deze projecten beter op waarde te kunnen schatten en ze verder te brengen. Small wins zijn kleine, maar diepgaande veranderingen met tastbare resultaten. Er zijn negen projecten geselecteerd, waar potentiële small wins aan het ontstaan zijn. Potentieel, omdat er veel mooie ambities en innovatieve ideeën zijn, maar concrete resultaten of echte diepgaande verandering nog niet altijd zichtbaar zijn. Dat komt onder meer omdat de projecten nog in een pril stadium verkeren en aanlopen tegen barrières in bestaande overheids- en marktinstituties. In interactie met betrokkenen zijn handelingsperspectieven ontwikkeld om deze small wins verder te verspreiden, te verbreden en te verdiepen. Een van de conclusies is dat PTRN veel in gang heeft gezet, maar dat de mogelijke ondersteunende functies van de PTRN nog niet ten volle zijn benut en niet structureel zijn ingebed en daarmee geborgd. Dit is wel noodzakelijk om transities in gang te zetten (kiemen) en verder te brengen.

A Participation Table Regional Networks (PTRN) has supported various projects in the past three years to further the transition to a sustainable society through new arrangements, ranging from area cooperatives to food councils. This report analyzes to what extent the small wins approach can help to better estimate the results of these projects and to take them further. Small wins are small but profound changes with tangible results. Nine projects have been selected where potential small wins are emerging. Potentially, because there are many nice ambitions and innovative ideas, but concrete results or real profound change is not always visible. This is partly because the projects are still at an early stage and come up against barriers in existing government and market institutions. Action perspectives have been developed in interaction with those involved to further spread, broaden and deepen these small wins. One of the conclusions is that PTRN has initiated a lot, but that the possible support functions of the PTRN have not yet been fully utilized and have not been structurally embedded and thus secured. This is necessary to initiate (germinate) and advance transitions.

Trefwoorden: coöperatie, DuurzaamDoor, gebiedscoöperatie, gemeenschap, nieuwe economie, Participatie Tafel Regionale Netwerken, PTRN, small wins, sociale innovatie, transities

Dit rapport is gratis te downloaden van https://doi.org/10.18174/534136 of op www.wur.nl/environmental-research (ga naar 'Wageningen Environmental Research' in de grijze balk onderaan). Wageningen Environmental Research verstrekt geen gedrukte exemplaren van rapporten.

2020 Wageningen Environmental Research (instituut binnen de rechtspersoon Stichting Wageningen Research), Postbus 47, 6700 AA Wageningen, T 03174807 00, www.wur.nl/environmental-research. Wageningen Environmental Research is onderdeel van Wageningen University \& Research.

- Overname, verveelvoudiging of openbaarmaking van deze uitgave is toegestaan mits met duidelijke bronvermelding.

- Overname, verveelvoudiging of openbaarmaking is niet toegestaan voor commerciële doeleinden en/of geldelijk gewin.

- Overname, verveelvoudiging of openbaarmaking is niet toegestaan voor die gedeelten van deze uitgave waarvan duidelijk is dat de auteursrechten liggen bij derden en/of zijn voorbehouden.

Wageningen Environmental Research aanvaardt geen aansprakelijkheid voor eventuele schade voortvloeiend uit het gebruik van de resultaten van dit onderzoek of de toepassing van de adviezen.
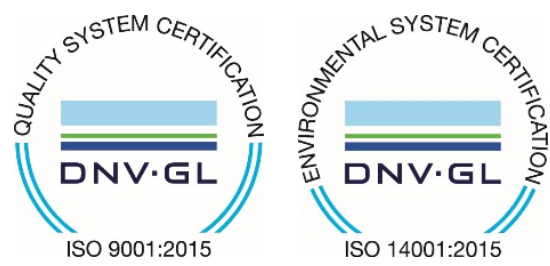

Wageningen Environmental Research werkt sinds 2003 met een ISO 9001 gecertificeerd kwaliteitsmanagementsysteem. In 2006 heeft Wageningen Environmental Research een milieuzorgsysteem geïmplementeerd, gecertificeerd volgens de norm ISO 14001.

Wageningen Environmental Research geeft via ISO 26000 invulling aan haar maatschappelijke verantwoordelijkheid.

Wageningen Environmental Research Rapport 3039 | ISSN 1566-7197

Foto omslag: Afbeelding is vervaardigd door Anne van Strien (afbeelding kiem) 


\section{Inhoud}

Verantwoording $\quad 5$

$\begin{array}{ll}\text { Woord vooraf } & 7\end{array}$

$\begin{array}{ll}\text { Samenvatting } & 9\end{array}$

S.1 Vraagstelling en methode van onderzoek 9

S.2 Belangrijkste uitkomsten $\quad 9$

$\begin{array}{ll}\text { S.3 Aanbevelingen } & 10\end{array}$

1

\section{Inleiding}

$\begin{array}{lll}1.1 & \text { Introductie } & 11\end{array}$

1.2 Vraagstelling $\quad 12$

$\begin{array}{lll}1.3 & \text { Aanpak } & 13\end{array}$

$\begin{array}{ll}\text { Analysekader } & 15\end{array}$

$\begin{array}{lll}2.1 & \text { Inleiding } & 15\end{array}$

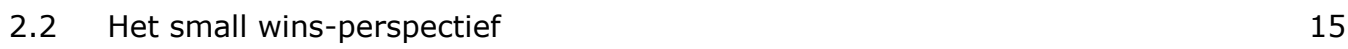

$\begin{array}{lll}2.3 & \text { Strategie van small wins } & 17\end{array}$

$\begin{array}{lll}2.4 & \text { Small wins herkennen en identificeren } & 17\end{array}$

$\begin{array}{ll}2.5 & \text { Accumulatie van small wins } \\ 2.6 & 18\end{array}$

$\begin{array}{lll}2.6 & \text { Bevorderen of afremmen van small wins } & 18\end{array}$

3 Oprichting Food Council Metropolitan Regio Amsterdam $\quad 21$

$\begin{array}{lll}3.1 & \text { Introductie } & 21\end{array}$

$\begin{array}{lll}3.2 & \text { Herkennen en identificeren van small wins } & 21\end{array}$

$\begin{array}{lll}3.3 & \text { Verspreiden, verbreden en verdiepen } & 24\end{array}$

$\begin{array}{ll}3.4 & \text { Aanjaagmechanismes } \\ \end{array}$

4 Right to challenge voor zorg en welzijn in stadsdorp Elsrijk te Amstelveen 26

4.1 Introductie $\quad 26$

4.2 Herkennen en identificeren van small wins 26

$\begin{array}{lll}4.3 & \text { Verspreiden, verbreden en verdiepen } & 29\end{array}$

4.4 Aanjaagmechanismes 30

$5 \quad$ CoöperatieAuto $\quad 31$

5.1 Introductie $\quad 31$

5.2 Herkennen en identificeren van small wins 31

5.3 Verspreiden, verbreden en verdiepen 33

$\begin{array}{lll}5.4 & \text { Aanjaagmechanismes } & 34\end{array}$

6 Tafeldemocratie van de Vereniging Noorden Duurzaam in drie pilots

$\begin{array}{lll}6.1 & \text { Introductie } & 35\end{array}$

6.2 Herkennen en identificeren van small wins $\quad 35$

$\begin{array}{lll}6.3 & \text { Verspreiden, verbreden en verdiepen } & 39\end{array}$ 
7.2 Herkennen en identificeren van small wins 40

7.3 Verspreiden, verbreden en verdiepen $\quad 42$

$\begin{array}{lll}7.4 & \text { Aanjaagmechanismes } & 43\end{array}$

8 Reflexieve monitoring coalitie Groen verbindt in AlblasserwaardVijfheerenlanden

8.1 Introductie $\quad 44$

8.2 Herkennen en identificeren van small wins 44

8.3 Verspreiden, verbreden en verdiepen $\quad 46$

$\begin{array}{lll}8.4 & \text { Aanjaagmechanismes } & 47\end{array}$

$9 \quad$ Oprichting Coöperatie Bommelerwaar $\quad 48$

$\begin{array}{lll}9.1 & \text { Introductie } & 48\end{array}$

9.2 Herkennen en identificeren van small wins $\quad 48$

9.3 Verspreiden, verbreden en verdiepen $\quad 51$

$\begin{array}{lll}9.4 & \text { Aanjaagmechanismes } & 51\end{array}$

$10 \quad$ Oefenrechtbank Notter Zuna

$\begin{array}{lll}10.1 & \text { Introductie } & 52\end{array}$

10.2 Herkennen en identificeren van small wins $\quad 52$

10.3 Verspreiden, verbreden en verdiepen $\quad 55$

$\begin{array}{lll}10.4 & \text { Aanjaagmechanismes } & 55\end{array}$

11 Project 'Vreedzaam leren en doen' van de Gebiedscoöperatie Rivierenland 56

$\begin{array}{lll}11.1 & \text { Introductie } & 56\end{array}$

11.2 Herkennen en identificeren van small wins $\quad 57$

11.3 Verspreiden, verbreden en verdiepen $\quad 59$

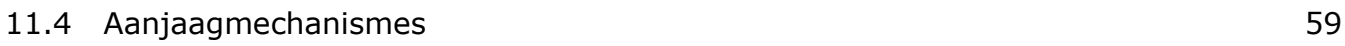

12 Vergelijking van negen casussen $\quad 60$

12.1 Negen praktijken: echte voorbeelden van small wins? 60

$\begin{array}{lll}12.2 & \text { De negen praktijken verder brengen } & 66\end{array}$

12.3 Handelingsperspectieven en aanjaagmechanismes voor accumulatie
van small wins

13 Conclusies en aanbevelingen $\quad 73$

$\begin{array}{ll}\text { Literatuur } & \mathbf{7 4}\end{array}$

$\begin{array}{lll}\text { Bijlage } 1 \quad \text { Vragenlijst } & 76\end{array}$

$\begin{array}{lll}\text { Bijlage } 2 & \text { Interviews en bijeenkomsten } & 77\end{array}$ 


\section{Verantwoording}

Rapport: 3039

Projectnummer: 5200045898

Wageningen Environmental Research (WENR) hecht grote waarde aan de kwaliteit van zijn eindproducten. Een review van de rapporten op wetenschappelijke kwaliteit door een referent maakt standaard onderdeel uit van ons kwaliteitsbeleid.

Akkoord Referent die het rapport heeft beoordeeld,

functie: $\quad$ senior onderzoeker Landscape Governance

naam: Wim de Haas

datum: $\quad 5$ augustus 2020

Akkoord teamleider voor de inhoud,

naam: Wies Vullings

datum: $\quad 4$ november 2020 


\section{Woord vooraf}

De Participatie Tafel Regionale Netwerken (PTRN) heeft de afgelopen drie jaar verschillende projecten ondersteund om de transitie naar een duurzame samenleving verder te brengen door middel van nieuwe arrangementen, variërend van gebiedscoöperaties tot voedselraden. Echter, deze projecten lieten zich moeilijk vergelijken en evalueren, omdat ze verschillende theoretische invalshoeken hanteren en omdat tastbare resultaten van nieuwe arrangementen niet direct zichtbaar zijn. Vanuit de PTRN is daarom aan ons gevraagd om alle projecten eens vanuit dezelfde invalshoek te benaderen: de theorie van de small wins. Dit om de resultaten van de projecten beter op waarde te schatten, te bezien hoe de projecten zich tot elkaar verhouden, hoe de resultaten zijn verder te brengen en welke meer algemene lessen er zijn te trekken voor de PTRN.

Dit rapport beschrijft negen projecten die werden ondersteund vanuit de Participatie Tafel Regionale Netwerken (PTRN), RVO/DuurzaamDoor. Het geeft aan in hoeverre deze initiatieven zijn te beschouwen als small wins, welke diepgaande veranderingen er zijn gerealiseerd en tegen welke barrières ze zijn aangelopen. Tevens biedt dit rapport een bescheiden bijdrage over hoe de resultaten van deze projecten zijn verder te brengen in termen van verspreiden, verbreden en verdiepen. Dit rapport beoogt daarmee ook een handelingsperspectief te bieden. We hebben slechts een deel van de ondersteunde projecten door PTRN kunnen bestuderen en hebben die projecten alleen vanuit het small wins-perspectief bestudeerd. Dit rapport is daarmee nadrukkelijk geen evaluatierapport. Binnen de PTRN zijn van alle projecten afzonderlijke rapporten verschenen die meer recht doen aan de beschrijving van de projecten. Dit rapport is verder niet bedoeld om te beoordelen of het geld vanuit de overheid wel goed is besteed. Het is geen financiële audit.

Wij willen alle geïnterviewden bedanken voor hun tijd en openhartigheid tijdens de gesprekken. Ook de zorgvuldigheid waarmee zij reageerden op door ons geproduceerde teksten waarderen wij zeer. Tot slot gaat een woord van dank uit naar Louise Boelens en Anne van Strien. Zij stelden ons - met tostemming van de door hen geïnterviewden - geluidsopnames beschikbaar van telefonische gesprekken met vertegenwoordigers van de casussen waardoor wij niet alleen over extra empirisch materiaal beschikten, maar ook goed voorbereid onze interviews ingingen.

Wij wensen de lezers veel leesplezier toe,

Marcel en Katrien 


\section{Samenvatting}

\section{S.1 Vraagstelling en methode van onderzoek}

De Participatie Tafel Regionale Netwerken (PTRN) wil nagaan hoe zij de opbrengsten van projecten beter op waarde kan schatten en verder kan brengen. Hiertoe zijn twee hoofdvragen gesteld:

1. In hoeverre en op welke manier kan de small wins-aanpak helpen om de resultaten van DuurzaamDoor/PTRN beter te identificeren en zichtbaar te maken?

2. Welke handelingsperspectieven biedt het toepassen van de small wins-aanpak voor het verder brengen van de transitieambities van DuurzaamDoor/PTRN?

Het onderzoek bestond uit raadpleging van rapporten en websites over de casussen, interviews en twee workshopbijeenkomsten. Zowel de resultaten van de interviews als de analyse zijn bij de geïnterviewden teruggelegd ter controle op correcte weergave.

\section{S.2 Belangrijkste uitkomsten}

De Participatie Tafel Regionale Netwerken (PTRN) heeft de afgelopen drie jaar verschillende projecten ondersteund om de transitie naar een duurzame samenleving verder te brengen door middel van nieuwe arrangementen. De small wins-aanpak helpt om de resultaten van deze projecten beter op waarde te kunnen schatten en ze verder te brengen. Small wins zijn kleine, maar diepgaande veranderingen met tastbare resultaten. Transities kunnen ontstaan door een accumulatie van small wins. Handelingsperspectieven zijn daarbij gericht op het verspreiden, verbreden en verdiepen van small wins.

Er zijn negen projecten geselecteerd, waar potentiële small wins aan het ontstaan en soms ook al aan het accumuleren zijn, te weten: Food Council, Right to challenge, CoöperatieAuto, Tafeldemocratie, Toogdialoog, Reflexieve monitoring en vitaliteitsdiagnose, Gebiedscoöperatie, Oefenrechtbank en Vreedzaam leren en doen. Ze kennen stuk voor stuk heldere ambities en ontwikkelen innovatieve concepten. Deze aanzetten zien er veelbelovend uit en zijn mogelijk te interpreteren als small wins, maar het is vaak nog te vroeg om vast te stellen of de projecten daadwerkelijk tot de voorgestane institutionele veranderingen leiden. Door een combinatie van missie, energie, doorzettingsvermogen en gunfactor zijn veel barrières overwonnen, maar er moeten er ook nog veel geslecht worden zoals vastzittende overtuigingen, gebrek aan (continuïteit in) financiering of langs elkaar werkende overheden.

Nagegaan is welke handelingsperspectieven er voor de PTRN en de deelnemers zijn om projecten verder te brengen: te verspreiden, te verbreden en te verdiepen. Uit de handelingsperspectieven voor de PTRN kan worden opgemaakt dat:

- de handelingsperspectieven door de PTRN en de overheden nog niet volledig zijn benut om het gedachtegoed van projecten te verspreiden, te verbreden en te verdiepen.

- de PTRN een cruciale rol speelt of kan spelen bij het verspreiden, verbreden en verdiepen. De functies die de PTRN vervult, zijn niet geborgd na 2020.

- die borging niet automatisch vanzelf zal gaan. Als een voortzetting van de PTRN er niet in zit, zullen de taken van de PTRN zo veel mogelijk elders geborgd dienen te worden om regionale netwerken te kunnen ondersteunen.

De hoofdconclusie is daarmee dat het verspreiden, verbreden en verdiepen deels is gebeurd, maar dat er op papier nog veel meer ambities zijn. De potentiële ondersteunende functies van de PTRN aan projecten hiervoor zijn nog niet ten volle benut en niet structureel geborgd. Dit was voor de deelnemende projecten wel noodzakelijk om transities in gang te zetten (kiemen) en verder te 
brengen. De PTRN zou de small wins graag benutten om transities te versnellen. Dit rapport biedt daarvoor enkele aangrijpingspunten, maar transities zijn niet maakbaar en kosten tijd. Om veranderingen te laten indalen, zijn er culturele en institutionele veranderingen nodig die zich niet gemakkelijk laten versnellen, nog afgezien van de vraag of deze vanuit de PTRN überhaupt beïnvloedbaar zijn.

\section{S.3 Aanbevelingen}

Vanuit de bestudeerde projecten is gebleken dat het voor hun impact belangrijk is dat de PTRN voort bestaat dan wel de functies die de PTRN vervulde elders te beleggen, opdat initiatiefnemers van vernieuwende projecten die aanzetten tot institutionele verandering, ook in de nabije toekomst een steun in de rug ervaren. Wanneer projecten in regionale netwerken al een beetje gedragen worden vanuit de PTRN of overheden, is dit reden voor initiatiefnemers om de moed niet op te geven. Dat dragen kan bijvoorbeeld bestaan uit financiering of een platform bieden voor kennis- en ervaringsuitwisseling. Uiteraard blijft er dan voor initiatiefnemers van projecten nog steeds veel energie, tijd en gedrevenheid nodig om ambities om te zetten in concrete resultaten en de initiële small wins te verspreiden, te verbreden en te verdiepen. 


\section{$1 \quad$ Inleiding}

\subsection{Introductie}

De Participatie Tafel Regionale Netwerken (PTRN) is een van de acht participatietafels die zijn ingesteld vanuit het programma DuurzaamDoor. De PTRN heeft de afgelopen drie jaar verschillende projecten ondersteund om de transitie naar een duurzame samenleving verder te brengen door middel van nieuwe arrangementen, variërend van gebiedscoöperaties tot voedselraden. Dit rapport analyseert in hoeverre de small wins-aanpak kan helpen om de resultaten van deze projecten beter op waarde te kunnen schatten en ze verder te brengen. Small wins zijn kleine, maar diepgaande veranderingen met tastbare resultaten. Voor wie bekend is met het programma DuurzaamDoor en de aanpak via participatietafels, wordt aanbevolen verder te lezen vanaf paragraaf 1.2 . Voor anderen volgt nu eerst een toelichting.

DuurzaamDoor ${ }^{1}$ is een multistakeholder-kennisprogramma van overheden en maatschappelijke organisaties, waarvan het programmabureau is ondergebracht bij de Rijksdienst voor Ondernemend Nederland (RVO). DuurzaamDoor brengt overheden en maatschappelijke initiatieven samen, waarbij leren en samenwerken centraal staan. Het bouwen van netwerken, verbinden en delen van leerervaringen hebben als doel om duurzame ontwikkelingen te versnellen.

DuurzaamDoor wil voor een omgeving zorgen waarin maatschappelijk initiatieven makkelijker kunnen worden uitgevoerd. Zij willen het uitvoerproces helpen versnellen en oplossingen voor prangende maatschappelijke thema's op grotere schaal toepassen. DuurzaamDoor hanteert de werkwijze en het instrumentarium van sociale innovatie. Sociale innovatie begint bij personen en organisaties die een maatschappelijk probleem zien en het plan opvatten er iets aan te doen. Veel maatschappelijke vraagstukken zijn zo ingewikkeld en hardnekkig, dat er geen eenvoudige oplossingen zijn. Burgers, ondernemers, organisaties met onderwijs, onderzoek en overheden bedenken vaak samen de oplossingen. Dat is 'sociale innovatie'. Cocreatie is een belangrijk onderdeel van DuurzaamDoor: 'het vormen van coalities die aan een gezamenlijke opgave werken'. DuurzaamDoor zet in op verschillende vormen van educatie: individueel leren, praktijkleren, sociaal leren, informeel leren en formeel leren. Sociaal leren is gezamenlijk leren in concrete praktijksituaties, in tegenstelling tot individueel leren. Informeel leren is het leren in een niet geformaliseerde setting, in tegenstelling tot formeel leren. Praktijkleren is het leren in een praktijksituatie, in tegenstelling tot op school leren.

Het programma DuurzaamDoor 2017-2020 bouwt voort op eerdere ervaringen en successen. Het programma speelt in op nieuwe speerpunten uit het Rijksbeleid en maatschappelijke ontwikkelingen. Een stuurgroep geeft richting aan het programma. Deze bestaat uit meerdere stakeholders. Daarin zitten vertegenwoordigers van de deelnemende bestuurslagen én landelijke vertegenwoordigers uit Onderwijs, Onderzoek, Ondernemers en Omgevingsorganisaties. Een breed programmateam met medewerkers van RVO.nl en vertegenwoordigers van partnerorganisaties voert het programma uit.

Centraal in de DuurzaamDoor aanpak staan de participatietafels ${ }^{2}$ die de inhoudelijke agenda's en projecten coördineren. Het gaat daarbij om concretisering en operationalisering van de maatschappelijke vraagstukken door alle betrokken actoren. Meepraten is meedoen door cocreëren, coalitievorming en cofinancieren. Hierover maken de deelnemers goede, meetbare afspraken. Op tafel komen zowel landelijke als regionale projecten en pilots. Participatietafels zijn creatieve samenwerkingsvormen. De projecten die voortvloeien uit werkzaamheden van de tafels worden op de website van DuurzaamDoor inzichtelijk gemaakt. Elke tafel is verbonden aan één thema:

biodiversiteit, circulaire economie, energie, omgevingswet, onderwijs, regionale netwerken, voedsel en water. De gezamenlijke stakeholders aan tafel stellen een 'portfolio' aan (leer)activiteiten en projecten

\footnotetext{
1 De tekst van deze paragraaf is gebaseerd op: https://www.duurzaamdoor.nl/over-duurzaamdoor

2 De tekst van deze paragraaf is gebaseerd op: https://www.duurzaamdoor.nl/over-duurzaamdoor
} 
samen met een goede balans tussen lokale, regionale en landelijke initiatieven. DuurzaamDoor streeft naar een kruisbestuiving en onderlinge versterking van maatschappelijke initiatieven 'van onderop' en de meer strategische acties.

Volgens DuurzaamDoor ${ }^{3}$ kunnen maatschappelijke vraagstukken effectiever worden aangepakt op regionaal niveau. Op regionaal niveau is volgens hen de slagkracht groter om tot oplossingen te komen dan op landelijk niveau. Want vaak komen meerdere taken op het gebied van duurzaamheid samen in één bepaald gebied of in een regio.

De Participatietafel Regionale netwerken (PTRN) ${ }^{4}$ is een ontmoetingsplek en een ontwikkelplek met als doel de overgang naar een duurzame leefomgeving te versnellen. In deze tafel komen overheden, burgerinitiatieven, universiteiten, hogescholen en professionele ondersteuners samen om nieuwe kennis te ontwikkelen, zodat regionale netwerken succesvol aan de slag kunnen gaan en de systeemwereld en leefwereld goed op elkaar aansluiten. De PTRN wil een slagvaardige impuls aan regio's geven om maatschappelijke opgaven te realiseren. Hierin erkent zij de verschillen in rollen, zoals in de leefwereld en de systeemwereld en in de ondersteuning van de proces- en kenniswerkers. De PTRN wil kleine lokale oplossingen bedenken voor grote opgaven, die het leren versnellen. De PTRN wil interactie, compassie en begrip voor elkaars rol stimuleren en om zo bij te dragen aan nieuwe inhoud en nieuwe werkvormen. De PTRN streeft naar succesvolle inzet van meervoudige waardecreatie in de regio. De start vond plaats in november 2017.

Vier keer per jaar bezoekt de PTRN een regio, waarbij twee à drie urgente opgaven centraal staan. Deze behandelen betrokkenen vanuit de systeem- en de leefwereld, met ondersteuning van procesen kennismensen. Zo worden twee tot drie projecten geïnitieerd, gericht op lokaal succes binnen een halfjaar. In de projecten wordt kennis ontwikkeld die elders ook toepasbaar is.

De indeling systeemwereld en leefwereld (afkomstig van de Duitse filosoof Jürgen Habermas) wordt door DuurzaamDoor gebruikt om de verhouding tussen burgers, overheid en professionals te beschrijven, om vervolgens de onderlinge samenwerking te verbeteren. De 'Leefwereld' is voor DuurzaamDoor de typering voor actieve burgers en ondernemende maatschappelijke initiatieven. Mensen werken daar met elkaar vanuit een passie. Dat doen ze vaak niet geordend, maar met veel vrijwillige inzet, verspreid over de hele week. Hun doel is 'verbetering' van hun eigen leefomgeving, zoals wijk of buurt. De 'Systeemwereld' zijn volgens DuurzaamDoor organisaties die al lang bestaan. Dat zijn bijvoorbeeld overheden, bedrijven en grote maatschappelijke organisaties. De systeemwereld kent vaste procedures en regels en mensen werken er met een bepaald weekritme.

\subsection{Vraagstelling}

Het programma DuurzaamDoor vindt het small wins-concept, zoals ontwikkeld door Katrien Termeer en voortbouwend op ideeën van organisatiedeskundige Karl Weick, interessant als ordenend principe. Het wordt gezien als een theorie over adequaat handelen in transities. Daaruit volgt een lens om naar initiatieven te kijken. Alhoewel small wins als lens verleidelijk klinkt, roept het ook nog veel vragen op. Hoe ziet dat eruit als je het toepast? Hoe werkt het? Welke condities heb je ervoor nodig? De vraag is om dat te onderzoeken aan de hand van de opgaven van de Participatietafel Regionale Netwerken. De bedoeling is ook dat dit onderzoek de opgaves van de Participatietafel Regionale Netwerken weer een stap verder brengt. Tot slot is de vraag om aan te geven hoe de methode van small wins kan helpen voor de transitieopgave van DuurzaamDoor.

Tegen deze achtergrond formuleren we de volgende vragen:

1. In hoeverre en op welke manier kan de small wins-benadering helpen om de resultaten van de Participatietafel Regionale Netwerken beter te identificeren en zichtbaar te maken?

2. Welke handelingsperspectieven biedt het toepassen van de small wins-benadering voor het verder brengen van de transitieambities van de Participatietafel Regionale Netwerken?

\footnotetext{
3 https://www.duurzaamdoor.nl/meer-over-regionale-netwerken

4 https://www.duurzaamdoor.nl/participatietafel-regionale-netwerken
} 
Deze vragen zullen in eerste instantie worden beantwoord in de context van de participatietafel regionale netwerken. Op basis van deze ervaring zullen ook wat meer generieke inzichten getrokken worden voor (andere participatietafels van) DuurzaamDoor.

\section{$1.3 \quad$ Aanpak}

De aanpak was als volgt. Na kennismaking met de opdrachtgevers is een werksessie georganiseerd met de deelnemers aan de Participatietafel Regionale Netwerken (PTRN) op 03/02/2020. Het doel van deze werksessie was om het concept van de small wins te introduceren, het concept van de small wins te verbinden met de ambities en opgaven vanuit de PTRN. Hierna volgde selectie van negen geschikte praktijken: voorbeelden van projecten binnen de PTRN, oftewel negen potentiële small wins. Om praktijken te kunnen bestuderen die vanuit de PTRN zijn ondersteund in de afgelopen 3,5 jaar, hebben wij de opdrachtgevers (voorzitter en secretaris van de PTRN) om een lijst gevraagd met projecten. Er zijn de afgelopen 3,5 jaar te veel projecten ondersteund om allemaal te kunnen bestuderen binnen dit onderzoek. Wij hebben daarom drie belangrijke criteria voor selectie van de casussen gehanteerd:

- selecteer projecten met potentiële small wins.

- daarmee samenhangend, selecteer projecten die daadwerkelijk in de praktijk, te weten regionale netwerken, zijn toegepast om te kunnen bezien of er daadwerkelijk veranderingen in de praktijk zijn gebracht en hoe dit ging. Theoretische verdiepende projecten van de PTRN vielen daarmee buiten beschouwing. Het is ons vooral te doen om projecten die bij anderen veranderingen teweegbrengen.

- selecteer projecten van personen die meerdere projecten binnen de PTRN gehonoreerd hebben gekregen. Dat betekent dat vooral projecten zijn geselecteerd van personen die twee of drie projecten hebben gedaan. Deze personen hebben daarmee een langere geschiedenis met de PTRN en kunnen zodoende wat breder reflecteren op de bijdrage van de PTRN aan projecten. Dit zou ook nog een positief effect kunnen hebben op verspreiding, verbreding of verdieping.

Op basis van toepassing van deze criteria zijn wij tot een selectie van de volgende negen casussen gekomen:

\begin{tabular}{|c|c|c|c|}
\hline Casus & Projectnummer PTRN & Projectnaam bij DD & Trekker \\
\hline $\begin{array}{l}\text { 1. Oprichting Food Council } \\
\text { Metropolitan Regio Amsterdam }\end{array}$ & JLE2017118 (2017) & Voedsel Verbindt & MRA Foodcounil \\
\hline $\begin{array}{l}\text { 4. Tafeldemocratie van de } \\
\text { Vereniging Noorden Duurzaam } \\
\text { in } 3 \text { pilots }\end{array}$ & DD2201947 (2019) & Try-out Gebiedstafel & Noorden Duurzaam \\
\hline $\begin{array}{l}\text { 5. Toogdialoog van Organisatie } \\
\text { Lijnspel om Flitscoöperatie } \\
\text { (energie) voor Heerlen Centrum } \\
\text { te richten }\end{array}$ & DD2201951(2019) & $\begin{array}{l}5000 \text { zonnepanelen voor de } \\
\text { Binnenstad van Heerlen }\end{array}$ & Lijnspel \\
\hline $\begin{array}{l}\text { 7. Oprichting Gebiedscoöperatie } \\
\text { Bommelerwaar; implementatie } \\
\text { Rijnlands gebiedsmodel }\end{array}$ & JLE2017121 (2017) & $\begin{array}{l}\text { Coöperatie Bommelerwaar- } \\
\text { Stroom }\end{array}$ & Coöperatie Bommelerwaar \\
\hline 8. Oefenrechtbank Notter Zuna & JLE2017119 (2017) & $\begin{array}{l}\text { Het Rijnlands } \\
\text { Gebiedsarrangement }\end{array}$ & Coöperatieve Samenleving \\
\hline
\end{tabular}


Voor de dataverzameling (in de periode van januari tot en met eind maart 2020) bij de casussen is gebruikgemaakt van websiteanalyse, documentanalyse (veelal ook rapporten die voor de PTRN zijn gemaakt), geluidsopnames gemaakt van telefonische gesprekken met een (of meerdere) vertegenwoordigers van ieder van de negen geselecteerde voorbeelden, die gemaakt werden door twee andere onderzoekers (Louise Boelens en Anne van Strien) als voorbereiding voor de podcasts die zij maakten voor de PTRN van de projectervaringen en met toestemming van de geïnterviewden naar ons mochten worden doorgestuurd. Tot slot hebben wij zelf interviews afgenomen. Voor de interviews maakten we gebruik van een vragenlijst (bijlage 1 ) die het stramien volgde van de small wins-theorie (toegelicht in hoofdstuk 2): a) small wins herkennen en identificeren, b) het verder brengen van small wins door verspreiden, verbreden en verdiepen en c) het accumuleren van small wins door toepassing van aanjaagmechanismes om tot concrete handelingsperspectieven te komen voor de PTRN dan wel casushouders. Alle interviews zijn telefonisch afgenomen met een tijdsduur van drie kwartier tot anderhalf uur.

Het onderzoek is uitgevoerd tijdens coronatijd. Voorafgaand aan het onderzoek hebben we één fysieke bijeenkomst gehad met de deelnemers van de PTRN. Na het verzamelen van de data zijn de casussen beschreven en geanalyseerd. De tweede workshop waarin we het casusmateriaal vergeleken en op zoek gingen naar handelingsperspectieven voor verder aanjagen van small wins vanuit de overheid algemeen en PTRN in het bijzonder, moesten we noodgedwongen digitaal houden. In deze digitale werksessie met de Participatietafel Regionale Netwerken (PTRN) op 15/04/2020 zijn de bevindingen gedeeld en is gesproken over het verder brengen van de small wins en mogelijke handelingsperspectieven voor de PTRN. Tot slot is dit rapport geschreven.

Dit rapport bestaat uit drie delen. Hoofdstuk 2 vormt het eerste deel waarin de small wins-benadering als analytisch kader wordt toegelicht. Het tweede deel van het rapport bestaat uit de toepassing van de small wins-benadering op negen casussen. In hoofdstuk 3 tot en met 11 worden de negen casussen gepresenteerd. Het laatste deel van het rapport is hoofdstuk 12, waarin de casussen worden vergeleken en geanalyseerd. 


\section{Analysekader}

\section{$2.1 \quad$ Inleiding}

Transities genieten al zo'n twintig jaar warme belangstelling. Transities duiden op systeemveranderingen op de lange termijn die ingrijpend zijn. Voor beleidsmakers, politici en ondernemers zijn er weinig handvatten om concreet aan transities vorm te geven. Met het noemen van de lange termijn en ingrijpende systeemwijzigingen lagen transities voor velen meteen ook heel ver weg. Zo werken veranderingen niet, dacht Katrien Termeer vanuit een jarenlange ervaring in veranderingstrajecten. Dat bracht haar ertoe om het perspectief van de small wins te ontwikkelen, daarbij onder meer kijkend naar theorievorming van Weick (1984) en Lindblom (1959) over muddling through: kleine stapjes). De theorie over small wins is nog niet geheel uitgekristalliseerd. Bestudering van praktijken en gesprekken met ondernemers, initiatiefnemers en beleidsmakers zorgen nog steeds voor aanscherpingen. Het valt op dat small wins soms worden verward met quick wins, 'laaghangend fruit' of 'klein bier'. Maar small wins zijn meer dan dat.

\subsection{Het small wins-perspectief}

Small wins beginnen met een ambitie (zie figuur 2.1), die voortkomt uit bijvoorbeeld de constatering van misstanden of uit de verwondering over gemiste kansen. Wat wil je veranderen, bereiken of verbeteren? Het kan daarbij gaan om kleine veranderingen, maar dat klein valt niet samen met een small win. Een small win is wel klein, maar groot in effect, doordat het bijdraagt aan systeemverandering en bevat ook aanjaagmechanismes voor verandering. Small wins zijn 'kleine maar betekenisvolle stapjes, die - indien de goede mechanismes worden geactiveerd - kunnen accumuleren tot systeemverandering. Bij een consequente strategie van 'small wins' kan systeemverandering zelfs sneller verlopen dan wanneer wordt gestuurd op snelheid en grootschaligheid' (Termeer, 2018: p.3).

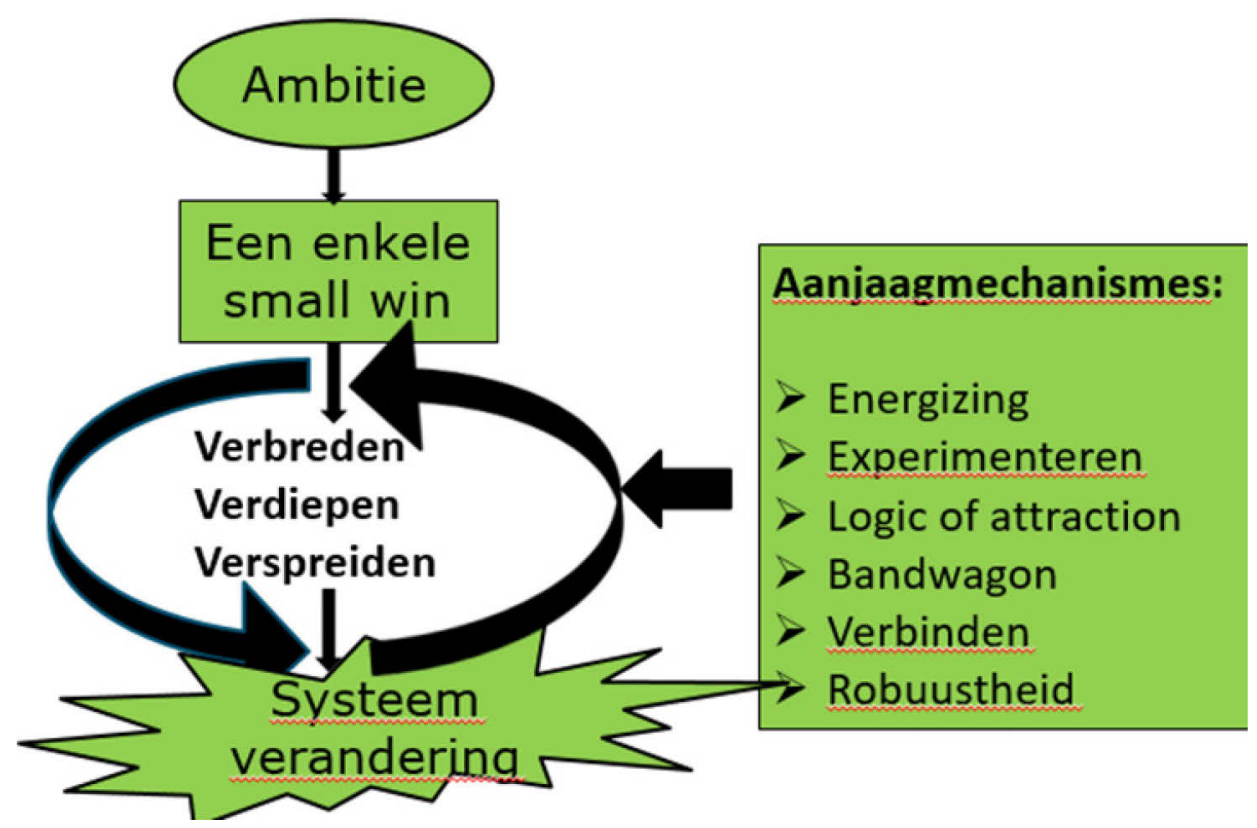

Figuur 2.1 Het small wins-perspectief (Bron: Termeer, 2018: p.6) 
Het gaat bij small wins niet om klein bier (zie ook titel rapport: Meer dan klein bier! (Termeer, 2019), laaghangend fruit en quick wins, maar altijd om initiatieven of praktijken die een diepgaande verandering betreffen, veel barrières hebben moeten overwinnen, tastbare resultaten opleveren en technische innovaties koppelen aan sociale innovaties. Via het activeren van aanjaagmechanismes draagt bijvoorbeeld de PTRN bij aan het verspreiden, verbreden en verdiepen van innovaties.

Een kleine verbetering is dus geen small win (zie figuur 2.2). Als er echt sprake is van een transitie, dan verandert er ook institutioneel het nodige. Een afdeling inkoop bestaat dan bijvoorbeeld niet meer. Koop en eigendom worden anders. Er ontstaan andere identiteiten en waarden.

\section{Transities}
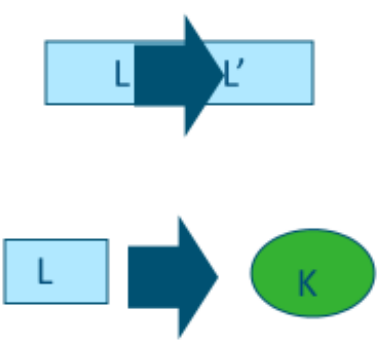

L1

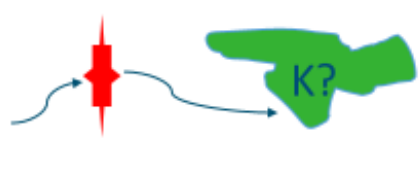

WAGENINGEN

\section{1e orde: Verbetering}

Hetzelfde doen op een

betere manier. Project.

$\mathrm{T}=$ enkele maanden

\section{2e orde:}

Transformatie

Nieuwe technologie en

nieuwe relaties.

Programma. $\mathrm{T}=$ vele jaren

\section{3e orde: Transitie}

Nieuwe waarden, identiteiten en

instituties, nieuwe culturen.

Leerproces. $T=$ minimaal een

generatie

Figuur 2.2 Transities (Termeer, 2020)

Transities voltrekken zich vaak over generaties (zie figuur 2.2). Om diepgaande veranderingen te realiseren, zijn immers nieuwe waarden, nieuwe relaties, nieuwe identiteiten, nieuwe instituties en daarmee nieuwe structuren en culturen nodig. Dergelijke diepgaande veranderingen zijn niet snel te realiseren. Bestuurders hebben doorgaans niet zo veel geduld met transities. Ze vinden dat eigenlijk alles tegelijk moet. Veranderingen moeten diepgaand zijn, veranderingen moeten snel zijn (in ieder geval binnen vier jaar als je er electoraal nog iets aan wil hebben) en moeten eigenlijk systeem-breed voor verandering zorgen (zie figuur 2.3).

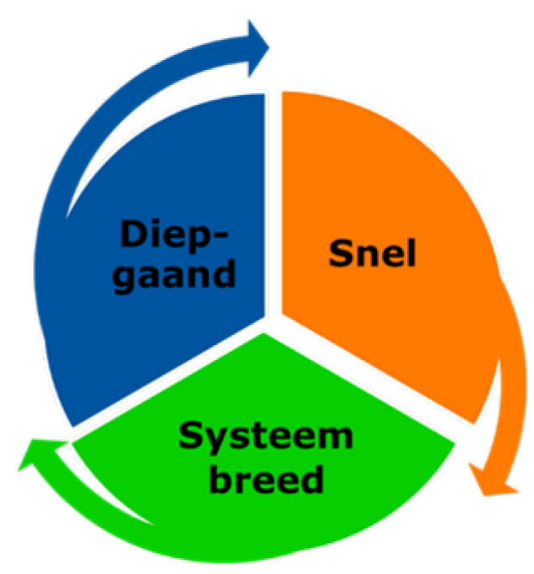

Figuur 2.3 Dilemma's bij transities (Termeer \& Dewulf, 2017) 
De wensen van bestuurders kunnen vaak niet allen tegelijk worden ingewilligd. Als het snel moet, is het vaak niet meer diepgaand, maar eerder oppervlakkig. Als het voor heel Nederland moet, is het systeem breed, maar vaak niet meer snel. De tip is om te beginnen vanuit diepgaande veranderingen en vandaar te kijken hoe je de andere bewegingen kunt maken.

\subsection{Strategie van small wins}

De strategie bij small wins is om ambities te formuleren die prikkelen en ruimte bieden. Vervolgens gaat het om te werken aan deze ambitie door kleine betekenisvolle stapjes te zetten met zichtbare resultaten. Dus: klein beginnen en diepgaander. Meteen een groot vraagstuk bij de kop pakken is vaak te overweldigend, te abstract en leidt vaak tot vaag taalgebruik. Een kleinere schaal houdt mensen scherp en voorkomt cynisme of verlamming. Want zeg nu eerlijk: hoe vaak denkt u niet bij het horen van het woord transitie: daar gaan we weer... het zoveelste transitiepad bewandelen dat ons het bos in stuurt. Uiteindelijk is het sneller, verwijzend naar Lindblom (1959): muddling through. Je kunt snel willen gaan, maar het gaat niet sneller dan het kan. Als je van de kelder naar de zolder probeert te gaan, kan je proberen te springen, maar het gaat vaak toch sneller als je via de trap gaat. Vaak gaan small wins sneller dan beoogde grote veranderingen, omdat de kleine omvang van small wins tot minder (politieke) risico's leidt, small wins onder de radar blijven, small wins minder weerstand en media-aandacht krijgen en small wins starten met onvolledige informatie. Bij transities is er altijd onzekerheid. We hebben de neiging om eerst alles te willen weten. Weick (2001) zegt hierover dat je organisaties pas kunt begrijpen door deze te willen veranderen. In complexe, nietlineaire systemen kunnen kleine stapjes resoneren in systeem-brede verandering. Daarbij is uiteraard de vraag: welke mechanismen doen dit? Daar komen we straks nog op terug.

\subsection{Small wins herkennen en identificeren}

De neiging kan bestaan om alle initiatieven of praktijken te willen aanmerken als small wins. Het gaat er vaak niet om dat praktijken of initiatieven worden gediskwalificeerd, maar als veranderingen te gemakkelijk worden doorgevoerd, zijn deze eerder aan te merken als kleine verbeteringen en niet als small wins. Om small wins te herkennen en erkennen, wordt voor prakijken of initiatieven het volgende nagegaan (tabel 2.1).

Tabel 2.1 Small wins herkennen en identificeren (Termeer \& Dewulf, 2017; 2018)

\begin{tabular}{|c|c|}
\hline Eigenschap & Beschrijving \\
\hline Kleine stap & Het is een initiatief op relatief kleine schaal en korte termijn. \\
\hline Op weg naar ambitie/ systeemverandering & Niet iedere kleine stap is een small win. \\
\hline Diepgaande verandering & Is er een echte omslag in denken en doen? \\
\hline $\begin{array}{l}\text { Overkomen bijbehorende wrijving en slechten van } \\
\text { barrières }\end{array}$ & Innovaties botsen per definitie met gangbare instituties. \\
\hline Verbinding inhoudelijke en sociale verandering & $\begin{array}{l}\text { Diepgaande verandering heeft altijd een technische en een sociale } \\
\text { dimensie. }\end{array}$ \\
\hline $\begin{array}{l}\text { Plek met energie om verder te leren en } \\
\text { experimenteren }\end{array}$ & De kleine stap genereert energie bij betrokkenen. \\
\hline
\end{tabular}




\subsection{Accumulatie van small wins}

Small wins kunnen accumuleren. Daarbij zijn positieve feedbackloops belangrijk. Hierbij zijn zes verschillende aanjaagmechanismes te onderscheiden, die kort worden opgesomd (Termeer en Metze, 2019; Termeer, 2018: p. 7-8):

- Energizing: Het zichtbare resultaat van een small win geeft mensen een directe beloning en sterkt hen in de overtuiging dat ze verschil kunnen maken. Wanneer het lukt om een kleine winst te behalen, inspireert dat om verdere stappen te zetten. Er ontstaat dan een zichzelf versterkend proces van commitment, optimisme en vertrouwen in elkaar en in de resultaten. Deze positieve energie zit in zowel de technische kant (hét is gelukt) als de sociale kant (het is óns gelukt).

- Experimenteren: Iedere small win is een experiment waarin mensen hun expliciete en impliciete aannames toetsen, zicht krijgen op weerstand en steun en verrassende effecten ontdekken. Al deze opbrengsten genereren meer inzicht in het weerbarstige vraagstuk en ideeën voor nieuwe experimenten, ook bij onverwachte of negatieve resultaten.

- Logic of attraction: Winnaars (wins) hebben aantrekkingskracht. De zichtbare resultaten van een kleine stap laten zien dat er potentie is en bieden een toegenomen zekerheid voor meer succes. Dit trekt mensen en middelen aan en genereert bereidheid om regels of financieringsmodellen aan te passen. Het vieren en het in de schijnwerpers zetten van positieve stappen versterkt dit effect.

- Olievlekwerking: Dit mechanisme duidt op een groepsdynamisch principe waarbij mensen volgen wat andere mensen doen. Een soort zwaan-kleef-aan-effect. Het sluit aan op het diffusiemodel van innovaties met vroege en late aanpassers.

- Verbinden: Dit mechanisme betekent dat een kleine verandering op een plaats in het systeem consequenties kan hebben voor veranderingen op andere plekken. Vaak gaat het om verbindingen tussen activiteiten op verschillende schaalniveaus of om problemen in andere beleidsdomeinen.

- Robuustheid (onomkeerbaar): Als er op meer plekken gelijktijdig kleine stappen gezet worden, kan dat leiden tot een bredere beweging. Small wins hebben de eigenschap dat ze lange tijd onder de radar blijven en daarmee redelijk ongevoelig zijn voor vroegtijdige beëindiging. Op het moment dat ze veel maatschappelijke en/of politieke aandacht krijgen en dus ook meer weerstand zullen oproepen, zijn ze vaak al zo talrijk dat het moeilijk wordt om het terug te draaien. De geest is op dat moment uit de fles. Veel actoren hebben dan de voordelen van de small wins geïnternaliseerd, waardoor ze onderdeel zijn geworden van nieuwe routines en instituties: het nieuwe normaal. Meerdere kleine stappen kunnen daardoor een steviger fundament bieden dan één grote oplossing.

\subsection{Bevorderen of afremmen van small wins}

Voor het bevorderen of afremmen van transities is het van belang om ook de bredere context te bezien van waaruit wicked problems ofwel grote ongestructureerde vraagstukken zijn te benaderen. Het aanhangen van andere benaderingen kan verklaren waarom small wins worden afgeremd.

Een klassieke reactie op een ongestructureerd vraagstuk is het formuleren van een 'grote oplossing'. Hoe zo'n 'grote oplossing' of 'grand design' eruit moet zien, leidt al snel tot lange en verlammende discussies in de planfase. Doorgaans zijn er volgens Termeer en De Wulf (2017) twee reacties van beleidsmakers en politici op ongestructureerde vraagstukken. De eerste mogelijke reactie is doen alsof het een gemakkelijk oplosbaar vraagstuk is en een tweede reactie is in cynisme vervallen en er in berusten dat het niet oplosbaar is. In het eerste geval creëert de overheid beloftes die niet zijn waar te maken en in het tweede geval gebeurt er, ondanks de ervaren urgentie, niets.

Naast deze twee extreme reacties vormen transitiebenaderingen een mogelijk alternatief. Transitiebenaderingen verschillen van elkaar. De Haas et al. (2020) onderscheiden vier verschillende benaderingen van transities: 1 ) een overheidsmanagementbenadering, 2) een institutionele benadering, 3) een small win-benadering en 4) een benadering vanuit transitietheorie.

Vanuit een overheidsmanagementbenadering van transities is een transitie een noodzakelijk antwoord op een aantoonbare, grote en inhoudelijke uitdaging. Het is een uitdaging waarbij de overheid het voortouw moet nemen; de overheid is een deel van de oplossing. Alleen overheidsbeslissingen hebben 
een legitieme impact. De overheid is de enige actor die over een breed instrumentarium beschikt en de legitimiteit heeft om ontwikkelingen af te dwingen.

In een institutionele benadering van transities wordt relatief veel aandacht besteed aan macht in de institutionele theorie. Instituties worden niet als deterministisch beschouwd: actoren vormen evenzeer instituties als dat zij erdoor beïnvloed worden. Een transitie wordt beschouwd als een herconfiguratie van institutionele bevoegdheden. Dit houdt meer in dan nieuwe economische of sociale configuraties, maar omvat ook het vestigen van een nieuwe legitimiteit binnen de wereld van instituties. Dit herconfiguratieproces gaat niet uit van een gestructureerd proces waarin beleid wordt gevormd, maar is aan de andere kant ook geen incrementeel proces. Het is een soort 'georganiseerde anarchie', met vloeiende coalities, opportunistische agenda's en een gebrek aan overzicht voor iedereen.

In een small win-benadering van transities krijgen transities gestalte door herhaalde reeksen van kleine overwinningen, gebaseerd op zorgvuldige observatie en gerichte acties (Dewulf et al., 2010); grotere problemen worden omgezet in kleinere, minder opwindende problemen, zodat mensen een reeks beheersbare kansen van bescheiden omvang kunnen identificeren die zichtbare resultaten opleveren en die kunnen worden samengevoegd tot synoptische oplossingen (Weick, 1984). Daarbij moeten transities niet worden gezien als een verandering van het ene systeem naar het andere via fasen (inclusief een periode van niet-lineaire disruptieve verandering en bijbehorende bestuurlijke interventies), maar als een continu proces.

Tot slot is er de benadering van transities vanuit de transitietheorie, waarbij transities verschillende fases doorlopen die een S-curve vormen en gemodelleerd worden naar een drielaags proces. Transities doorlopen hierbij vier verschillende fasen, die een S-curve volgen: (1) een voorontwikkelingsfase van dynamisch evenwicht waarin de status quo niet zichtbaar verandert; (2) een startfase waarin het veranderingsproces start omdat de toestand van het systeem begint te veranderen; (3) een doorbraak- of versnellingsfase waarin zichtbare structurele veranderingen plaatsvinden door een opeenstapeling van sociaal-culturele, economische, ecologische en institutionele veranderingen die op elkaar reageren. Tijdens de versnellingsfase zijn er collectieve leerprocessen, diffusie- en inbeddingsprocessen en ten slotte (4) een stabilisatiefase, waarin de snelheid van sociale verandering afneemt en een nieuw dynamisch evenwicht wordt bereikt.

De vier genoemde benaderingen van transities vertonen overeenkomsten. Alle benaderingen zijn gebaseerd op veranderingen op de lange termijn. Alle vier veronderstellen ook complexiteit en een zekere mate van chaos. Alle benaderingen gaan ervan uit dat de overheid een transitie als geheel niet kan beheren. Bij alle benaderingen is een mentaliteitsverandering belangrijk. Alle benaderingen benadrukken het fundamentele karakter van overgangen. Uit deze overeenkomsten kan worden opgemaakt dat de vier benaderingen complementair kunnen zijn aan elkaar of onafhankelijk van elkaar parallel kunnen worden toegepast. In alle benaderingen is opschalen en verspreiden belangrijk. Praktijken zijn verder te brengen door ze te:

- Verspreiden: praktijk opschalen of uitrollen door deze ook elders (andere locaties) toe te passen.

- Verbreden: praktijk toepassen op andere terreinen en verbinden met andere vraagstukken, het basisidee toepassen in andere ketens, producten, probleem domeinen.

- Verdiepen: praktijk nog radicaler maken.

Het accumuleren van small wins is geen lineair proces en niet vooraf te plannen. Wel zijn er aanjaagmechanismes die het accumuleren van small wins kunnen bevorderen dan wel afremmen: zie tabel 2.2. 
Tabel 2.2 Voorbeelden van productieve en contraproductieve interventies (Termeer, 2019).

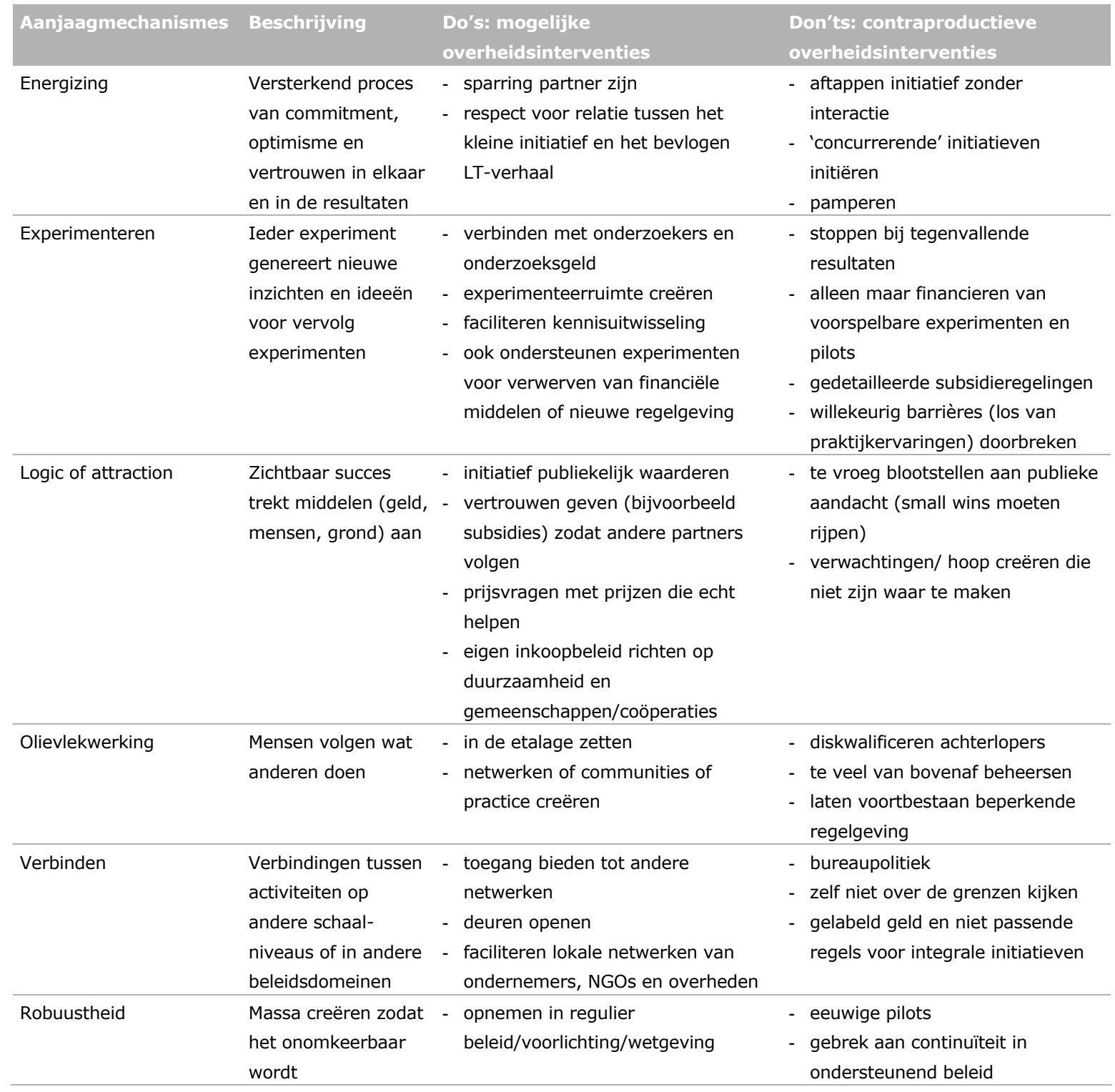

Met dit hoofdstuk is het perspectief van de small wins-theorie toegelicht en zijn we klaar om:

- te reflecteren op negen PTRN-initiatieven door een small wins-bril;

- te analyseren wat de potentie van de PTRN-initiatieven is voor verspreiden, verbreden en verdiepen;

- concrete handelingsperspectieven voor casussen en PTRN te ontwikkelen en adresseren.

Voor de casusbeschrijvingen die nu volgen, zijn documenten en websites geraadpleegd. Ook zijn gesprekken gevoerd met de initiatiefnemers dan wel met begeleiders van de initiatieven. Allen zijn leden van de PTRN, veelal procesadviseurs en zzp'ers.

Bij de casusbeschrijvingen is relatief veel aandacht uitgegaan naar de barrières, omdat we de redenen wilden weten waarom initiatieven al dan niet verder komen en hierop aan te sluiten met handelingsperspectieven hoe barrières weggnomen of verminderd kunnen worden en initiatieven verder gebracht kunnen worden.

Tijdens het lezen van de casussen zal de lezer meermalen het gevoel krijgen of nu wel of niet van een small win kan worden gesproken. Een small win is een kleine stap met tastbare resultaten, waarbij die resultaten een begin vormen van een diepgaande verandering. Een kleine stap wordt daarmee dus gerelateerd aan de diepgaande verandering. Dat maakt het relatief wat er gedaan is onder de kleine stap. Vaak wordt gezegd dat het best al een behoorlijke stap is en dat die toch niet klein is, maar vaak is dit wel het geval wanneer deze stap wordt afgezet tegen de diepgaande verandering. 


\section{Oprichting Food Council Metropolitan Regio Amsterdam}

\subsection{Introductie}

De Food Council Metropolitan Regio Amsterdam (FC MRA) is in 2017 opgericht. De initiatiefnemers hebben zich laten inspireren door Wayne Roberts, het boegbeeld van de stedelijke voedselbeweging uit Toronto (Canada). Een van de initiatiefnemers is geïnspireerd geraakt tijdens een sabbatical die hij in 2011 in New York heeft doorgebracht. New York zat toen in een vergelijkbare periode die Amsterdam nu doormaakt, namelijk dat een groot deel van de bevolking zich bewust begint te worden welke problemen er zijn met voedselproductie.

De FC MRA is aan de slag met duurzame, gezonde voedselproductie in en om steden en brengt producenten en consumenten bijeen in een regionaal platform waar de meest uiteenlopende organisaties elkaar informeren en inspireren tot actie. De FC MRA richt zich met de MRA op de gemeente Amsterdam en omliggende gemeenten als Haarlem en Almere. Ook heeft de FC MRA goede contacten met de provincies Noord-Holland en Flevoland.

\subsection{Herkennen en identificeren van small wins}

De kleine stap die is gezet is de oprichting van de Food Council MRA met voedselconsumenten en -producenten, waarmee ook een organisatie ontstond voor het verbinden van voedselinitiatieven voor en door burgers. Tastbare resultaten zijn: de oprichting van de FC MRA, het houden van voedselmanifestaties, het regelen van grond voor de verbouw en het bewerken en consumeren van voedsel, voedselinitiatieven ondersteunen, een manifest met doorwerking naar Amsterdams gemeentebeleid, wekelijkse bijeenkomsten bij AMS (Amsterdam Institute for Advanced Metropolitan Solutions) en excursies naar verschillende voedselinitiatieven waar veel kennisuitwisseling plaatsvindt. De diepgaande verandering is gericht op een voedseltransitie, gericht op het transparanter maken van het voedselsysteem, een rechtvaardiger en gezonder voedselsysteem, voedselsoevereiniteit en voedseldemocratie. De small win is het oprichten van de nieuwe organisatie. Deze dient afgezet te worden tegen de diepgaande verandering die wordt nagestreefd. De activiteiten van de nieuwe organisatie zijn tastbare resultaten die als voorbode kunnen worden gezien van de gewenste diepgaande verandering.

De (deels) overwonnen barrières zijn als volgt toe te lichten:

Financiën. In 2017 is de oprichting van de voedselraad gelukt, zowel met de krachten van de status quo (zie onder barrières) als met de financiële steun van de Rabobank en de provincie Noord-Holland en Flevoland. De oprichting van de Voedselraad voor de Metropoolregio Amsterdam moest met een grote klap gebeuren vanwege het feit dat de FC MRA in één keer iets neer wilde zetten. De initiatiefnemers hebben de beurs van Berlage afgehuurd, waarmee een van de initiatiefnemers een enorm financieel risico nam. Ze leerden improviseren. De initiatiefnemers hadden contacten met de lokale directeur van de Rabobank. Die heeft het extra benodigde bedrag bijgelegd. Ook de provincie Noord-Holland heeft bijgestaan in het verder financieel haalbaar maken. Er was in die kringen behoefte om stapjes vooruit te maken. De samenwerking met partijen zoals de provincies en de Rabobank voor de ondertekening van het regionale voedselmanifest en de organisatie van het congres 'Flows of Food' heeft evidente voordelen gehad, maar er zijn zeker ook nadelen. De meest in het oog springende is financiële afhankelijkheid (Van der Valk et al., 2018: p.6). Geldschieters proberen de Food Council te gebruiken voor het verwerven van legitimatie van continuering van traditionele praktijken, terwijl de Food Council juist streeft naar innovatie. 
De FC MRA heeft altijd moeite gehad om het hoofd financieel boven water te houden. De FC MRA wil het liefst geen subsidie van overheden. Het is niet zo dat zij geen geld willen aannemen, maar zij willen onafhankelijk blijven (want: wiens brood men eet, diens woord men spreekt). De FC MRA wil daarom eigen nieuwe verdienmodellen ontwikkelen. De programmamanager van de voedseltransitie van de gemeente Amsterdam stelt (nog) geen geld beschikbaar voor de FC MRA, omdat de gemeente haar eigen koers wil varen. Binnen de voedselbeweging zijn veel organisatie-concullega's. Er is veel verdeeldheid, omdat alle clubjes uit dezelfde subsidieruif proberen te eten. "Sommige mensen uit de voedselbeweging zijn actief in het onderwijs, dan lukt het over het algemeen nog wel om te verdienen. Het merendeel is afhankelijk van kleine subsidies. De concurrentie die daaromheen ontstaat, maakt dat de neuzen niet allemaal dezelfde kant op staan."

Het ontbreken van reguliere financiële middelen is, achteraf bezien, een prikkel geweest om een kerngroep van loyale vrijwilligers op te bouwen. De beide oprichters vormen de onbetaalde spil van deze groep van vrijwilligers. (Van der Valk et al., 2018, p.5). Het ontbreken van reguliere financiële middelen en vaste kantoor- en vergaderruimte blijft een beperking (Van der Valk et al., 2018: p.5-6). AMS zou ruimte beschikbaar stellen; na de verhuizing was het niet meer mogelijk. Er waren allemaal nieuwe mensen gekomen, contactpersonen vielen weg.

Regelgeving. Bij de oprichting van de FC MRA is een regionaal manifest opgesteld als bekroning van de bijeenkomst. Een aantal van de partijen die het manifest hebben ondertekend (de provincies), hebben eerst juristen naar de tekst laten kijken. Wat resteerde, was een manifest waar in radicale bewoordingen wordt opgeroepen tot een transformatie van het voedselsysteem. Overigens is regelgeving vanuit organisaties wat beperkend. Vernieuwing schrikt af als het verandering betekent van het bestaande.

Overtuigingen. De geïnterviewde initiatiefnemer wordt door verschillende overtuigingen gedreven. Zo benadrukt hij dat verandering van de mensen komt en niet zo zeer van de technologie. Maar dat de aandacht vanuit instituties nog steeds vooral op het laatste is gericht. Hij benadrukt dat mensen ertoe doen en dat het daarmee dus gaat om 'het kweken' van een bepaalde mentaliteit. Een andere overtuiging van de initiatiefnemer is dat de Food Council een regionaal netwerk dient te zijn, vanwege het feit dat landschap een belangrijk aspect is van de hele voedseltransitie. Dat is het schaalniveau waarop producenten en consumenten met elkaar in contact staan. De logistiek speelt zich ook voornamelijk af op regionaal niveau. Producenten en consumenten dienen daarbij in hetzelfde netwerk te zitten. Omtrent de deelnemers aan de voedselraad bestaat ook een duidelijke overtuiging bij de initiatiefnemer: "Het idee is om pragmatisch te beginnen en te proberen twee losse sferen van de voedselwereld met elkaar te verbinden, namelijk het conventionele circuit van wereldwijde industriële voedselproductie en -distributie enerzijds en de alternatieve wereld van lokaal en biologisch voedsel aan de andere kant" (Van der Valk et al., 2018: p. 2). Omtrent de samenstelling van de deelnemers wordt een brede samenstelling beoogd: "De Food Council werkt vanuit een pluralistisch perspectief, dat wil zeggen dat ze zo veel mogelijk groepen in de samenleving bij het gesprek over voedseltransitie wil betrekken. Er wordt veel tijd en energie geïnvesteerd in het expliciteren en rechtdoen aan de verschillen in benadering tussen betrokken partijen in het discours" (Van der Valk et al., 2018: p.6). De initiatiefnemer is er verder van overtuigd dat de triple helix tekortschiet vanwege het ontbreken van burgers: "Voorheen werd alleen uitgegaan van de triple helix zijnde overheid, onderwijs/onderzoek en bedrijfsleven. Nu spreken we over een quadruple of penta helix. Het is duidelijk dat je niet meer alleen toekunt met overheden, bedrijven, banken en het onderwijs. Het is wel duidelijk dat burgerinitiatieven hier de hoeksteen zijn geworden. Dat is de belangrijkste win die wij voor elkaar hebben gekregen. Dat is een win in termen van mentaliteit."

Omtrent overheden is de initiatiefnemer positiever gestemd over de overheden in de regio dan over de gemeente Amsterdam. De initiatiefnemer vindt Haarlem heel voedsel-minded. Restaurants hebben zelf een programma opgezet voor preventie van voedselafval. Ze hebben volgens de initiatiefnemer een goede markt opgezet waar de boeren onderdeel van uitmaken. Ook Almere maakt volgens de initiatiefnemer passen vooruit, omdat er een wethouder zit die wat wil en kan, vanwege de aankomende Floriade die om voedsel draait. De provincie Noord-Holland begint volgens de initiatiefnemer ook meer in beweging te komen en de verwachting is dat dit wat kan worden, omdat zij voortvarend bezig zijn. Wat de gemeente Amsterdam betreft, merkt de initiatiefnemer op dat de 
cultuur binnen de gemeente Amsterdam totaal anders is dan de cultuur binnen de randgemeenten: "Dat is ook een belangrijke barrière voor verandering. Dat duurt voort tot op de dag van vandaag. Er wordt wel gesproken met elkaar. De tweedeling is minder ernstig dan in Noord-Amerika." Tot slot geeft de initiatiefnemer aan dat de sectorale opdelingen en de politieke cultuur waar iedere wethouder vecht voor zijn eigen portefeuille de voedseltransitie belemmert: "Voedsel valt, net als dierenwelzijn, nergens binnen de portefeuilles. Nieuwe thema's zijn vaak slecht belegd. Voedsel werd binnen gezondheid gepositioneerd. De opstellers wilden een interdisciplinaire aanpak. De nieuwe voedselstrategie is gebaseerd op een oude voedselvisie. Als Food Council lopen we nog vast op de gemeentelijke bestuurscultuur."

Middelen. De initiatiefnemer ziet vooral de jongeren en ouderen in Amsterdam als sociaal kapitaal dat het initiatief verder vooruit kan helpen: "Er is een 'heel leger' van mensen dat met pensioen gaat. Er loopt een heel leger aan talent rond in Amsterdam dat aan het verzuren en vereenzamen is. Het sociaal kapitaal zit verder vooral ook bij jonge mensen. Die willen in actie komen." De initiatiefnemer realiseert zich dat ook nog veel partijen ontbreken bij de voedselraad: "Minder machtige actoren, zoals etnische minderheden, kleine boeren, actiegroepen en kleinschalige voedselinitiatieven zijn buiten beschouwing gebleven in het manifest. $\mathrm{Er}$ is geen sprake van opzettelijke uitsluiting, maar de vertegenwoordigers van die groepen kunnen al te vaak geen tijd vrijmaken om deel te nemen aan het overleg op vrijdag in het AMS. Sommigen hebben geen geld om het transport naar de vergaderlocaties te betalen. De oprichters van de Food Council zijn zich bewust van dit euvel en ondernemen pogingen om extra middelen te verwerven teneinde de vertegenwoordigers van afwezige groepen in staat te stellen wel een bijdrage te leveren (Van der Valk et al., 2018: p.7)." Omtrent de middelen bestaat bij de initiatiefnemers dus grote ambities: "We willen dus het sociaal kapitaal benutten dat braak ligt in de stad en dat inschakelen. Dat lijkt laaghangend fruit, maar het is tegelijkertijd ook een moeilijke opgave, omdat je de hele organisatiestructuur hiervoor moet ontwikkelen."

Kennis en relaties. De initiatiefnemer geeft aan dat zijn achtergrond in de academische wereld als hoogleraar de oprichting van de FC MRA ten goede kwam. Allereerst via AMS en later via de UvA en VU. Verder heeft hij zelf heel veel aan de PTRN gehad.

$\underline{A M S}$ (een samenwerkingsverband van Wageningen Universiteit, Technische Universiteit Delft en het Massachusetts Institute for Technology uit Cambridge, MA) gaf status aan wat de initiatiefnemer deed, zowel richting ambtelijke circuits van provincie en gemeenten, maar ook richting burgerinitiatieven waar de verdeeldheid het grootst is. "Het AMS stelt tijdens de gehele beschreven periode vergaderruimte ter beschikking aan de Food Council-in-oprichting. De associatie met deze prestigieuze onderzoeksinstelling geeft cachet aan de wekelijkse bijeenkomsten van de Food Council-in-oprichting (2018, p. 4)." En: "De vaste bijeenkomsten op vrijdag in het gebouw van AMS in het KIT (Koninklijk Instituut voor de Tropen) vormen een ankerpunt in de activiteiten van de oprichters. Tijdens deze bijeenkomsten groeit de onderlinge solidariteit en kristalliseert een voorlopige werkagenda uit. Naast het AMS verleent ook Pakhuis de Zwijger incidenteel onderdak aan de oprichters en hun gevolg van voedselactivisten, studenten, academici, ambtenaren, journalisten en geïnteresseerde burgers (2018, p.4)." De initiatiefnemers reflecteren op de rol van hun relaties: "Gebruikmakend van bestaande netwerken en contacten heeft de FC MRA een niche geschapen waarbinnen in eerste instantie voornamelijk academici participeren. Door het succesvolle congres 'Flows of Food' is het recruteringsveld aanzienlijk verbreed naar bedrijfsleven, burgerinitiatieven en overheden. Het ontbreken van reguliere financiële middelen en vaste kantoor- en vergaderruimte is daarbij een beperking (Van der Valk et al., 2018: p.5-6)."

Universiteiten. Een van de initiatiefnemers ontwikkelde een cursus voor de UVA (Universiteit van Amsterdam) over food in the city, future of food. Bij de universiteitsgebouwen van het science center stond een kraampje met studenten die aardappelen en groenten bij een boer in Waterland haalden en doorverkochten aan een kleine 100 studentklanten. Zij maken nu deel uit van de FC MRA. Verder is de geïnterviewde initiatiefnemer bij de VU (Vrije Universiteit Amsterdam) betrokken bij een Europees project dat voortkomt uit colleges voor VU-studenten. Die studenten zijn bezig met een green campus. Allemaal studentenverenigingen die aan vergroening willen werken. Een van de initiatiefnemers probeert dan de studenten van de VU en UVA met elkaar in contact te brengen. 
De PTRN heeft een van de initiatiefnemer enorm geïnspireerd. Hij had volgens eigen zeggen in de FC MRA nooit gedaan wat hij nu doet als de PTRN er niet was geweest. Waar hij zelf vooral theoretische kennis had, hadden de betrokkenen bij de PTRN veel ervaring met het mobiliseren en activeren van mensen, via methodes waar ook hij bij zweerde. Vanaf de eerste dag had hij het gevoel dat hij bij de club van de PTRN wilde horen. Het eerste jaar heeft hij zich stil gehouden en zich meer als leerling opgesteld. Na een jaar heeft hij ook meegedraaid met allerlei projecten van andere collega's. Hij vindt de PTRN een hele hechte kernclub, waar hij voor het eerst heeft ervaren wat van een community of practice mag worden verwacht en wat de meerwaarde daarvan is. Hij heeft het in de PTRN echt aan den lijve mogen ondervinden en mogen ervaren. Via de contacten van de PTRN is hij in contact gekomen met de Commons-beweging. Hij heeft de PTRN ervaren als een warm bad. De contacten, de community of practice is voor hem het waardevolst: "De PTRN is ook een heel speciale combinatie van persoonlijkheden. De mensen in de groepen hebben mooie capaciteiten en uiteraard ook zwakker ontwikkelde kanten. In het elkaar coachen ligt een behoorlijke potentie die nog niet helemaal benut is. Ik heb heel veel van de PTRN geleerd wat ik nooit in mijn eentje had kunnen bereiken. Het idee vanuit de PTRN om velddagen in te stellen was een grandioos idee. Dan moet je een gezamenlijke inspanning plegen waardoor je dichter tot elkaar komt. Met de PTRN kunnen we nog meer over de grenzen van de tafel heen kijken: contacten aanhalen met voedseltafel, de omgevingswettafel, de Commons-tafel. De community of practice van de PTRN is nog veel impliciete kennis. Het feit dat de PTRN met dit onderzoek van jullie en dat van de podcasts die kennis meer expliciet wil maken, is goed."

De initiatiefnemer ervaar ook barrières in relaties voor het initiatief van FC MRA: "Een deel van de krachten werkt binnen organisaties richting behoud van het bestaande. Zij doen moeilijk bij vernieuwende ontwikkelingen en willen controle houden over alles."

Omtrent de (deels) overwonnen barrières kunnen we concluderen dat de financiële middelen voor de FC MRA beperkt blijven. De FC MRA is vooral afhankelijk van vrijwilligers en daarmee van sociaal kapitaal. De regelgeving vanuit organisaties is wat beperkend. Vernieuwing schrikt af als het bestaande wordt geraakt. Culturele regels binnen gemeenten werken soms bevorderend, soms beperkend. Vooral de cultuur bij enkele organisaties en het ontbreken van financiën lijken de grootste bottleneck in deze casus. De FC MRA zet vooral in op jongeren en ouderen en willen graag meer mensen inzetten, maar de financiële middelen ontbreken voor een andersoortige organisatiestructuur waarbij nog meer mensen worden betrokken. Kennis en relaties worden binnen de FC MRA zo ingezet dat zij het initiatief bevorderen. De overtuigingen van de initiatiefnemer wijken sterk af van de nog dominante overtuigingen binnen de instituties, zowel voor de beoogde voedseltransitie als het proces hoe hiertoe te komen.

De verbinding tussen de inhoudelijke en sociale verandering bestaat uit inclusiviteit en sociale cohesie bij de voedseltransitie. De Food Council blijft door experimenteren en leren.

\subsection{Verspreiden, verbreden en verdiepen}

Het verspreiden gebeurt door nieuwe initiatieven te binden aan de FC MRA en via manifestaties, bijeenkomsten en excursies om kennis te delen. Een van de initiatiefnemers is zelf actief in de Voedseltuin IJplein. Besloten is om op te schalen en een symposium te organiseren: "In mei organiseren we een bijeenkomst (was nog voor de Coronatijd). Ze wilden de tuin als een voorbeeld laten zien aan de Commons en daarmee een huwelijk te sluiten met de Commons-beweging, waar heel veel sociaal kapitaal aanwezig is." Verbreden krijgt vorm door het streven om andere doelgroepen te bereiken: jongeren, gepensioneerden: "Het gaat om het benutten van sociaal kapitaal dat braakt ligt in de stad en dat inschakelen. Laaghangend fruit maar ook moeilijke opgave omdat je de hele organisatiestructuur hiervoor moet ontwikkelen." Ook gaat het om het verbreden richting boeren buiten de steden: "Korte ketens ontwikkelen. Heel veel boeren in de omgeving van Amsterdam willen nu wat." Een van de initiatiefnemers geeft nog een mooi voorbeeld van mensen die vaak niet zijn ingesloten als het om voedseltuinen gaat: "Het integratieproject bij het IJplein. Turkse en Marokkaanse mensen kwamen wel op de tuin af, maar deden niet mee. Er staan twee doelen in de statuten van Voedseltuin IJplein: voedsel voor de voedselbank en sociale cohesie bevorderen. Een Turkse vrouw had een keer illegaal op de tuin een uienveld aangelegd. Waarom kom je niet bij de 
tuin? Sprak met een Marokkaanse man die vroeger thuis ook een tuin had. Raakten aan de praat. Waarom kom je niet bij de tuin? Een gemeenschappelijke tuin is niets, willen een eigen tuin hebben. Het werd duidelijk dat ze graag een eigen stuk grond zouden willen hebben. Arnold heeft dat toen aangekaart. Er is toen een brandnetelhoek gereedgemaakt met metertuintjes. Er kwam een club van 15 Turkse vrouwen en twee mensen van Marokkaanse afkomst op af. Dat is één jaar als experiment gedaan. En nu voor het tweede jaar. De voorzitter is kunstenares en heeft hele mooie kleurennaamkaartjes gemaakt met buitenlandse namen en onze namen." Verdieping wil de initiatiefnemer realiseren door meer aandacht voor coachen en het opzetten van dialogen.

\subsection{Aanjaagmechanismes}

De oprichters van de FC MRA zien dat nieuwe verbindingen tussen mensen mooie resultaten opleveren. De achterban bestaat uit veel idealistische mensen. "Eén verkeerd woord en je wordt in de ban gedaan, maar daar moet je je niet door laten ontmoedigen." Het is steeds twee tot drie stappen vooruit en dan weer een stap of twee stappen terug. De oprichters zien dat mensen helemaal gaan voor de voedseltransitie en die kom je dan overal weer tegen. Die gaan net als de oprichters ook helemaal door het systeem heen (energizing). De FC MRA blijft voortdurend zoeken naar nieuwe vormen van ontmoetingen als experimenten. Zo zijn ze van plan een safari te organiseren voor boeren om ze in contact te brengen met hun achterban. Ze zoeken ook naar een nieuwe vorm om de boeren betrekken bij het maken van de voedselstrategie voor Amsterdam. Een grote voedselmanifestatie in de Beurs van Berlage en de ondertekening van een manifest door de betrokken partijen heeft veel positieve aandacht (Iogic of attraction) voor de FC MRA gegenereerd. In de beginfase is het netwerk vooral gegroeid als gevolg van het feit dat de oprichters mensen uit hun bestaande netwerk hebben benaderd. Het congres Flows of Food markeert een omslagpunt. Na 7 december 2018, de datum van het congres, hebben veel personen en organisaties uit eigen beweging contact gezocht met de oprichters. (2018, p.4). Via de PTRN is een van de oprichters in Amsterdam in contact gekomen met de Commons-beweging. Er zijn bij de Commons-beweging nog mensen die nog nauwelijks weten wat ze met de voedseltransitie kunnen. Die kan de FC MRA een werkveld aanbieden (olievlekwerking).

Vanuit de FC MRA worden tal van verbindingen gelegd: Een van de kernleden van de FC MRA heeft in Haarlem de club opgezet die nu met de restauranthouders bezig is.

- De stadstuinders in Haarlem staan in verbinding met Amsterdamse clubs. Ze komen vaak bij elkaar in Amsterdam-Noordoost.

- In Almere werkt een vriend van een van de initiatiefnemers bij de Aerus Hogeschool. Hij zet zich in Almere actief in voor de voedseltransitie.

- Een van de initiatiefnemers maakt vanuit zijn academische achtergrond ook verbinding met Wageningen en internationaal. Dit leidt tot mooie contacten en gastlezingen etc.

- Als foodcouncil helpen ze om uiteenlopende stadslandbouwinitiatieven te organiseren en er een belangenorganisatie voor te maken. Dat is recentelijk voor elkaar gekomen.

- $\mathrm{Er}$ is onlangs een voedselmanifest gemaakt als aanvulling op de voedselstrategie van de gemeente Amsterdam. De gemeente heeft aangegeven dat ze voedselstrategie met burgerinitiatieven verder wil vormgeven. Die handschoen is opgenomen door de FC MRA.

- Een van de mensen van PTRN stelde voor om alle initiatieven bij elkaar te halen. De FC MRA stemde in als er wat middelen voor de bijeenkomst vrijgemaakt konden worden. Dat is gebeurd. Het leidde volgens eigen zeggen tot een hele succesvolle bijeenkomst. Daar werken ze op verder.

- Een andere verbinding die de FC MRA probeert te maken, is om de wereld van de alternatieven in contact brengen met de conventionele voedselwereld. Dit wordt geprobeerd via Voedselverbindt en het platform voor burgerinitiatieven: "Het zijn totaal verschillende culturen, totaal verschillende opvattingen. In de ene wereld gaat het alleen om geld verdienen, in de andere wereld heb je allerlei idealistische ideeën. Om die werelden bij elkaar te brengen: dat is een langetermijnmissie."

Wat robuustheid betreft is de FC MRA nog niet financieel robuust en ontbeert een vaste vergaderlocatie. Anderzijds is de FC MRA op tal van manieren aan het verspreiden, verbreden en verdiepen en in die zin hebben ze zich genesteld en veel vrijwilligers aan zich weten te binden. 


\section{$4 \quad$ Right to challenge voor zorg en welzijn in stadsdorp Elsrijk te Amstelveen}

\subsection{Introductie}

In Amstelveen staan partijen in de driehoek overheid, markt, gemeenschap klaar om samen te werken rond welzijn en zorg. Het lukt nog niet zo goed als zij zich wensen. De gemeenschap bestaat uit Stadsdorp Elsrijk, een zorgcoöperatie, met op de achtergrond de landelijke koepel van zorgcoöperaties Nederland Zorgt voor Elkaar. De markt bestaat uit welzijnsaanbieder Participe, zorgaanbieder Amstelring en uit verzekeraars Zilveren Kruis en Zorg\&Zekerheid. De overheid bestaat uit de gemeente Amstelveen. De boodschap van de zorgcoöperatie is dat de markt en overheid te veel greep hebben op zorg en welzijn. Diepere boodschap is dat de gemeenschappen deze goederen deels uit het overheidsdomein en uit de (beperkte) marktwerking willen halen en naar de gemeenschap brengen. De overheid werkt hieraan actief mee met het instrument right to challenge uit de WMO, een manier om goederen en diensten uit het overheids- of marktdomein over te hevelen naar het domein van gemeenschappen. De overheid blijft opdrachtgever, op dat punt verandert niets, maar de uitvoering gaat van een marktpartij (welzijnsaanbieder, zorgaanbieder) naar de gemeenschap, die daarmee overigens ook een marktpartij wordt. De overheid blijft dit sturen. Het inzetten van het right to challenge komt voort uit de gedachte dat de bewoners van Elsrijk al jaren succesvol aan welzijn werken en al drie jaar lang zochten naar structurele financiering. Bij subsidie weten ze namelijk dat het een keer niet gaat lukken en dan valt alles neer wat ze hebben opgebouwd.

Bij deze casus adviseerde op de achtergrond de voorzitter van Nederland Zorgt voor Elkaar (NLZVE), de landelijke koepel van zorgcoöperaties.

\subsection{Herkennen en identificeren van small wins}

Het bewonersinitiatief Stadsdorp Elsrijk te Amstelveen maakt gebruik van het Wmo (Wet maatschappelijke ondersteuning) recht om de gemeente uit te dagen (right to challenge) dat zij betere welzijnsdiensten leveren aan de bewoners dan marktpartij Participe (kleine stap). De tastbare resultaten zijn dat bewoners van de wijk Elsrijk in Amstelveen veel meer zeggenschap hebben verkregen omtrent gewenste welzijnsdiensten. De diepgaande verandering betreft het deels overhevelen van taken rond welzijn vanuit overheid en markt naar de gemeenschap. Het idee is dat de gemeenschap betere welzijnsdiensten levert tegen lagere kosten. De (deels) overwonnen barrières zijn als volgt toe te lichten:

Financiën. Het College van B\&W van de gemeente Amstelveen heeft besloten om 120.000 euro toe te kennen aan (de Stichting) Stadsdorp Elsrijk. Dat geld zou eerst naar marktorganisatie Participe gaan, maar gaat nu naar Stadsdorp Elsrijk. Het is daarmee een challenge waar Participe het lid op de neus heeft gekregen. De voorzitter van NLZVE: "Participe gaf eerst aan te willen meewerken, maar B\&W heeft hard toegeslagen, wat Stadsdorp Elsrijk toch deels verraste. Er is nog een klein probleempje: het zou eigenlijk een gemeentebesluit moeten zijn volgens de wet. Stadsdorp Elsrijk verwachtte dat B\&W het eerst zou voorstellen aan de gemeenteraad en toen had B\&W al beslist." Stadsdorp Elsrijk is nu gemachtigd om 120.000 euro uit te geven. Waarschijnlijk gaan ze dat doen door een welzijnswerker in te huren via marktorganisatie Participe. Vermoedelijk heeft iedereen er op deze manier ook wel vrede mee, ook de mensen die achter Participe staan, want dan zijn alleen de rollen omgekeerd. De volgende keer dat er opnieuw geld wordt uitgezet door de gemeente hoopt de Stichting Stadsdorp Elsrijk dat er ook aan hen wordt gedacht en dat de huidige gunning dus niet eenmalig is. Stichting Stadsdorp Elsrijk wil een structurele positie krijgen bij aanbestedingen. De huidige gunning is volgens eigen zeggen een mooie mijlpaal, maar het zou structureel moeten worden. 
Regelgeving. De Wet maatschappelijke ondersteuning (Wmo) biedt de mogelijkheid aan eenieder om het recht om uit te dagen (Right to Challenge) in te zetten. In andere wetten, bijvoorbeeld de Wet ruimtelijke ordening (Wro), ontbreekt die mogelijkheid. Het recht om uit te dagen houdt in dat een partij aangeeft dat deze beter in staat is om welzijn en zorg te leveren tegen lagere kosten. De voorzitter van NLZVE: "Het is belangrijk dat de gemeente Amstelveen voor het recht om uit te dagen heeft opengestaan. Puur juridisch mogen ze zeggen: we werken er niet aan mee. De WMO heeft die mogelijkheid geschapen. Je komt er niet zomaar onderuit. Maar gemeenten kunnen zeggen dat ze er geen zin in hebben."

Opschalen vanuit een burgerinitiatief kan al snel op barrières vanuit regelgeving stuiten. De voorzitter van NLZVE hierover: "Zodra je opschaalt als burgerinitiatief en marktpartij begint te worden, moet je je aan de regels van de markt houden. Steun aan een bewonersinitiatief vanuit de overheid kan dan worden geïnterpreteerd als staatssteun." De voorzitter van NLZVE geeft een voorbeeld: "Een groep maatschappelijke ondernemers zegt met steun van VWS: 'we gaan 500 bewonersinitiatieven uitrollen'. Dan overtreed je de wet van de gemeenschap... Als burgerinitiatieven te veel opschuiven naar andere domeinen stuit je op bijbehorende barrières. Het gaat om de moderne trias politica tussen overheid, markt, gemeenschap. Als je daar de regels van overtreedt, corrigeren de domeinen elkaar. Als ik van een bewonersinitiatief te veel een marktinitiatief maak, lopen ze weg. Als bewoners ga je niet meedoen aan een initiatief dat je door een overheid of adviesbureau wordt opgedrongen. De wetten van de driehoek zijn streng. Doe je niet voor als bewonersinitiatief dat iets wil verkopen. Dan gaat de overheid zeggen: wat ben je nu? Dat zijn natuurlijke barrières. Je wordt teruggefloten door de wetten van je eigen domein of vanuit de andere domeinen."

Volgens de voorzitter van NLZVE is de wet maar beperkt een blokkade en hangt het vaak af van hoe personen het willen interpreteren: "Binnen de wet blijkt er vaak ruimte te zijn. Bij ruimte binnen wetten ben je afhankelijk van de opstelling van bijvoorbeeld wethouders. De ene wethouder wil inspelen op burgerinitiatief. De opvolgende wethouder wil geen aandacht besteden aan kleine groepen die uitzondering op het beleid willen zijn. Je kunt een wet pakken en zeggen dat het niet kan en wel kan. Het zit in de wil om te willen veranderen of ruimte te bieden. Een innovatiemedewerker van een zorgverzekeraar die ziet dat hij de zorg kan verbeteren en op kosten kan besparen, wil dat onderzoeken. Je bent dus ook afhankelijk van personen die er wat in zien."

Overtuigingen. Het initiatief van Stadsdorp Elsrijk komt voort uit de overtuiging dat een model met gemeenschappen en coöperaties betere kwaliteit en minder kosten met zich meebrengt. Volgens de voorzitter van NLZVE heeft Rijksuniversiteit Groningen (RUG) een rapport uitgebracht over het dorpsondersteuners-model: "Samenwerking en veranderend opdrachtgeverschap zou voor de cliënt, maar ook voor de zorgverlener zelf leuker en beter moeten zijn. Wij zien dat het beter wordt. Groningen heeft zich vooral gericht op kosten die naar beneden gaan." De voorzitter van de NLZVE heeft de overtuiging dat zorg dient te beginnen bij bewoners: "Historisch bezien werd je in de middeleeuwen ook bij de gemeenschap verzorgd. Dat hebben we tot diep in de $20^{\mathrm{e}}$ eeuw volgehouden. Met de verzorgingsstaat kregen mensen het idee dat zorg niet meer hun zorg was. De overheid heeft de zorg naar zich toe getrokken en daar wetten voor geschreven. Die wetten zitten in een groef. De burger en gemeenschap die werden uitgeschakeld, worden nu weer aangezet. Met Stadsdorp Elsrijk als koploper."

Volgens de voorzitter van NLZVE is sprake van duurzaamheid als het lang houdbaar is. Mensen in hun buurt zijn de stabiele factor: "Heel veel wetenschappelijke publicaties over burgerinitiatieven richten zich erop dat als burgers ermee stoppen, het stil valt. De discontinuïteit bij overheden en markt is vaak groter. Bewonersinitiatieven blijken behoorlijk stabiel te zijn. Naast overheid en markt krijg je er een stabiele partij bij, die in staat is kennis vast te houden, met politieke verschuivingen om te gaan. En om al te rare fusies in de markt af te vangen. De volatiliteit van de overheid en markt wordt deels gecompenseerd door de gemeenschap. Andersom werkt het ook: als een burgerinitiatief niet functioneert, heb je overheid en markt om het af te vangen."

Volgens de voorzitter van NLZVE is duurzaamheid ook elkaar controleren: "Als een burgerinitiatief elitair is en burgers uitsluit, dan moet de overheid daarop controleren en bij de volgende aanbesteding Stadsdorp Elsrijk overslaan. Partijen moeten elkaar controleren en beter maken." 
De gemeente Amstelveen heeft het burgerinitiatief eigenlijk van begin af aan omarmd. Stadsdorp Elsrijk daagde, in samenspraak met twee raadsleden, de gemeente Amstelveen uit om zelf invulling te geven aan het welzijnswerk in Elsrijk. De gemeente Amsterdam is volgens de voorzitter van NLZVE bijvoorbeeld veel minder gericht op burgerinitiatieven. De gemeente Amsterdam vindt volgens hem dat zij er als gemeente namelijk al voor de burger zijn: "Het huidige college van Amsterdam is overigens wel bereid tot het werken met commons (commons verwijst naar gedeelde bronnen en sociale praktijken die op een duurzame manier door gemeenschappen worden onderhouden). Bij de oprichting van een netwerk van commons is niet nagegaan wat er al aanwezig was aan bestaande burgerinitiatieven. De commons zijn invloedrijk richting B\&W. Ambtenaren laten zich vaak veel minder in met commons en burgerinitiatieven. Toch sijpelt het wel door in het ambtenarenapparaat als B\&W erachter staan. Veel stadsdorpen willen hun tijd niet aan de gemeente verspillen. Eigenlijk is dat doodzonde."

Kennis en relaties. De voorzitter van de NLZVE vindt de PTRN nuttig voor het delen van kennis en waarden: "De PTRN is vooral nuttig om te weten dat leden van de PTRN niet alleen staan in deze zaken, om de juiste mindset houden." De kennisuitwisseling binnen de PTRN kan volgens hem beter. Onderlinge producten worden slecht uitgewisseld en slecht gelezen. Wat boeiend is, is dat de groep van de PTRN echt zoekt naar de next step. Wat de voorzitter goed doet, is proberen te organiseren dat de groep bij de next step komt, terwijl die buiten bereik blijft. Er blijft tegelijkertijd ook iets onuitgesproken: het 'stand still, step forward'-principe. De stand still wordt in de PTRN nooit gemaakt. Het zou goed zijn om na te gaan wat de deelnemers aan de PTRN allemaal delen. Iets uitbeitelen wat we delen en dan als basisprincipes niet meer bespreken. Past dit bij werkwijze van de PTRN?"

De voorzitter van de NLZVE staat ambivalent tegenover een aantal theoretische en methodologische verhalen die in de groep rondgaan. "Daar zou de PTRN discussie over kunnen organiseren, waarbij leden kritischer naar elkaar zijn. Het zijn nu vooral mensen die elkaar energie geven. Als leden van de PTRN misschien te kritisch naar elkaar worden, ontstaat een totaal andere groep. De voorzitter van de PTRN laat nu mensen bijna tot in het onmogelijke op elkaars schouders staan om te reiken naar de next step, terwijl die er nog niet is. Misschien is de prijs die ervoor wordt betaald dat er een aantal verhalen tussen zitten die bij doorrekening niet kunnen. Het is een heel ijle groep. Die ijlheid is ook de kracht. Anders ontstaat een kritisch groepje wetenschappers, dan wordt de effectiviteit heel anders."

Omtrent de (deels) overwonnen barrières kunnen we concluderen dat voor Stichting Stadsdorp Elsrijk de financiën een barrière waren toen ze geen geld hadden. Nu vormen de financiën een stimulans. Omdat het om een aanbesteding gaat, is er geen continuïteit op financiering te bieden door de gemeente, maar wel op de erkenning als structurele aanbestedingspartner. Het recht om te dagen (right to challenge) binnen de WMO was een stimulans voor Stichting Stadsdorp Elsrijk. Deze stimulans biedt echter geen continuïteit voor de langere termijn. Daarnaast zitten achter de domeinen overheid, markt en gemeenschap verschillende mechanismen en logica's die zich als wetten laten begrijpen en die ook beperkingen stellen aan domeinvermenging en domeinverschuiving van coöperaties, burgerinitiatieven of gemeenschap richting overheid en/of markt. Wetten zelf zijn vaak maar beperkt een blokkade, het zijn vaak personen die de wet verschillend interpreteren. Qua overtuigingen ligt veel nadruk op de gemeenschap en hoe overheden, markt en de gemeenschap elkaar kunnen versterken en controleren. Deze overtuigingen dienen het op te nemen tegen de overtuigingen dat de overheden en de markt de zorg dienen te regelen. Wat de kennis en relaties betreft, wordt enerzijds gepleit voor betere kennisdeling en reflectie en op waardendeling, anderzijds wordt onderkend dat als dit te zwaar wordt aangezet, dit ten koste kan gaan van de energie in de groep.

Het instrument 'Right to challenge' leidde tot meer zeggenschap voor bewoners. Er ontstond zo een verbinding tussen een inhoudelijke en sociale verandering.

Stadsdorp Elsrijk voorziet in de mogelijkheid om kennis te delen: plannen en initiatieven via een eigen website. Het is daarmee een plek met energie om verder te leren en te experimenteren. 


\subsection{Verspreiden, verbreden en verdiepen}

Omtrent verspreiding geeft de voorzitter van NL ZVE aan dat het voor de gemeente Amstelveen belangrijk is dat het initiatief buiten Elsrijk gaat komen: "Dat zal niet met een doorbraak gaan. Dat zal gebeuren omdat Elsrijk groeit. Het zal gebeuren omdat anderen het oppikken. De gemeente heeft veel geleerd. Dat is belangrijk voor volgende stappen. De next step is: meer dan Elsrijk. Die stap is er nog niet." Verspreiding wordt dus allereerst gezocht naar andere wijken in Amstelveen: het kan zich uitbreiden naar een naastgelegen wijk of dorp. Verspreiding heeft volgens de voorzitter van NL ZVE ook gevolgen: "Je moet het dan ook over schaalvergroting hebben. Voor de geloofwaardigheid houden burgerinitiatieven zich ook weer graag aan een regionale grens, maar werken wel graag samen met andere burgerinitiatieven. Verspreiding zal moeten ontstaan door het ontstaan van nieuwe burgerinitiatieven in andere wijken. Gemeenten kunnen verspreiding stimuleren: als je ervan uitgaat dat burgers het al bedacht hebben maar elkaar nog niet hebben gevonden, dan maak je kracht van het potentieel van de bewoners. Dan kan je het verspreiden en vergroten. In Medenblik zijn er bijvoorbeeld mensen die het al bedacht hebben en bij elkaar gebracht worden." Er wordt ook verspreiding gezocht richting de gemeente Amsterdam. Vanuit 'Nederland Zorgt voor Elkaar' wordt Elsrijk aangehaald, omdat er 800 andere initiatieven zijn die ook naar cofinanciering zoeken. De voorzitter: "'Nederland zorgt voor elkaar' is aanjaagfunctie. Kennisdisseminatie, zorgfunctie doet de koepelorganisatie Nederland zorgt voor elkaar. Het werkt ook door via de markt voorbeelden te laten zien en deze bij andere dorpen te gaan proberen. Op een gegeven moment past het gewoon, het hangt in de lucht... de tijdsgeest is om het te verspreiden en te laten groeien."

Elsrijk verbreedt van welzijn naar zorg. Om te kunnen verbreden, is volgens de voorzitter van NLZVE de paardensprong nodig: "Bewonersinitiatieven maken paardensprongen als op een schaakbord. Waarom doen ze wat ze doen? Soms is het verrassend. Vaak zijn er positieve neveneffecten. Je zet een middel in voor een doel, maar dat doel blijkt dan weer een middel te zijn voor een ander doel. Dat is de paardensprong. Ze gaan dan voor een tweede doel. Er worden veel mensen gemobiliseerd en die gaan dan ook op de andere doelen inzetten. Waar de klassieke economie inzet op de doelen waar ze het meest kunnen verdienen en de neveneffecten laten liggen, pakken de burgerinitiatieven die wel op en maken daar hun maatschappelijke businesscases van en creëren daar heel veel waarde mee."

Verbreding zal dus vanuit bewoners zelf gebeuren, geholpen door gemeenten. Andere mogelijkheden voor verbreding zijn er: diversificatie... voedsel erbij pakken of duurzaamheid: "Mondjesmaat zie je dat andere doelgroepen worden betrokken. Jongeren deden heel spaarzaam mee. Of vooral inzetten op 60+ en niet op kinderen met een handicap. Verbreden betekent ook dat je moeilijke doelgroepen probeert mee te pakken. Het gaat allemaal langzaam. Naar de people kant zit er veel co-benefit in. Elsrijk is begonnen met zorg. Er is ook al een duurzaamheidsclub uit voortgekomen.

Bewonersinitiatieven pakken iedere keer weer iets nieuws op. Daar stoppen ze ook niet mee (voortdurend experimenteren)."

De zwakte bij de Right to challenge voor verdieping ligt volgens de voorzitter van NLZVE vooral bij de overheid: "De overheid heeft de behoefte om de bal af te spelen. Dus in de driehoek overheid, markt en gemeenschap wil de overheid dat ook. Wat wil de markt? Zien die niet ook in dat het beter wordt in coalities met de gemeenschap? Verdieping zou dan zitten in tripartisering die zich voortzet. Het is controle en elkaar beter maken. Maar ook elkaar beter maken en efficiënter met andere technologie, andere democratie. Bestaande producten krijgen dan verdieping, een ander gebruik, een andere functie. Het toepassen van andere technieken leidt ook tot een andere democratie. Wanneer technologie het mogelijk maakt om langer thuis te wonen, kunnen burgers hiernaar verwijzen in de democratie als dit aansluit bij hun wensen." 


\subsection{Aanjaagmechanismes}

Stadsdorp Elsrijk heeft veel energie om het right to challenge toe te passen. Een welwillende houding vanuit de gemeente Amstelveen maakt dat de energie verder wordt versterkt om het door te zetten (energizing). Stadsdorp Elsrijk is een plek waar de bewoners terechtkunnen met hun plannen en initiatieven (experimenteren). Op hun website kunnen ze pagina's maken waar bewoners zich kunnen uiten en waar zij informatie kunnen delen. Het toekennen van het budget aan Stadsdorp Elsrijk maakt dat de Stichting status verkrijgt: niet alleen bij de eigen bewoners, maar ook bij andere organisaties die zich op een andere manier tot de Stichting gaan verhouden, zoals marktorganisatie Participe (logic of attraction). Voor de gemeente Amstelveen is het belangrijk dat het model van werken van Stadsdorp Elsrijk ook buiten de wijk van Elsrijk in Amstelveen gaat komen. Dat zal vooral dienen te gebeuren omdat anderen het in andere wijken oppikken. De next step is: meer dan Elsrijk. Die stap is er nog niet (olievlekwerking). Bij de bewoners is sprake van het verbinden van sociale ontwikkelingen en technologie: zonder social media zouden burgerinitiatieven veel minder hard lopen. Een andere ontwikkeling is domotica: het inzetten van techniek waardoor je qua welzijn en zorg langer in je woning kunt blijven wonen. Denk daarbij aan melders, interfaces met artsen et cetera. Leveranciers en verzekeraars benaderen Stadsdorp Elsrijk om dit verder uit te breiden (verbinden).

Met het verkrijgen van het budget vanuit de gemeente Amstelveen is op de korte termijn robuustheid ontstaan. Op de lange termijn is nog onzeker of de Stichting Stadsdorp Elsrijk permanent wordt uitgenodigd bij aanbesteding vanuit de gemeente. 


\section{CoöperatieAuto}

\section{$5.1 \quad$ Introductie}

De CoöperatieAuto is tot stand gekomen door een nauwe samenwerking van VrijstadEnergie, LochemEnergie en de Hilversumse Energie Transitiecoöperaties met de Europese The Mobility Factory. De missie is een leefbare omgeving helpen creëren door samen elektrisch te rijden. Meer schone lucht, meer rust, meer plaats. Maar ook door meer hernieuwbare energie in hun auto's en in hun eigen buurt te krijgen.

Een bewonersinitiatief in Culemborg heeft zonnepanelen boven de gezamenlijke parkeerterreinen in de wijk EVA-Lanxmeer gerealiseerd. Momenteel wordt al stroom geleverd aan de wijk, maar niet op een slimme manier. Ingezet wordt op een slim laadplein waarbij via het energienet en via de cloudboxkastjes in de auto wordt bepaald wanneer het ideale moment is om de auto's te laden. Er kunnen 28 laadpunten worden gerealiseerd, afhankelijk van hoe het nieuwe laadplein wordt ingericht. Als de auto opgeladen is, kan een ander gaan laden. Er zijn nu zes laadpunten. CoöperatieAuto wil samen met VrijStadEnergie de volgende stap maken richting een energieneutrale wijk met een lokale smart grid. Ze willen ook de mogelijkheden onderzoeken om de accu's van elektrische (deel)auto's als buffer te gebruiken om de opwekpieken op te vangen. Veel bewoners doen financieel mee in dit project. Daarnaast leveren de provincie Gelderland, het Regionaal Investeringsfonds en de gemeente Culemborg een bijdrage om dit project mogelijk te maken. Voor het laadplein waren meerdere innovaties nodig om slim laden als de zon schijnt mogelijk te maken en ook te voorkomen dat auto's laadpunten bezet houden als de accu vol is. Verder blijkt dat het laadplein de mogelijkheid geeft om een winstgevende businesscase te ontwikkelen voor het zonnedak en het laadplein.

\subsection{Herkennen en identificeren van small wins}

De kleine stap bestaat uit de wens om een eigen park van coöperatieve, elektrische deelauto's op te richten. Het tastbare resultaat is als volgt weer te geven. In Culemborg was er eerst belangstelling van 6 tot 7 mensen voor 2 deelauto's; nu zijn het 20 mensen voor 4 deelauto's op locatie. Daarnaast is samen met de Coöperatie Vrijstad Energie een Zonnepark met 784 zonnepanelen ontwikkeld met een laadplein voor elektrische auto's. Eind maart 2020 zijn er 4 deelauto's op locatie. Fysiek is er ook een app ontwikkeld: de mobility factory, een Europese app voor alle coöperatieve initiatieven in Europa. De resultaten zijn dus een zonnepark, een laadplein, deelauto's, een app en een gestart proces voor het opwaarderen van het laadplein. De diepgaande verandering is de E-Deelauto als vehikel voor realisatie van klimaatdoelen en mobiliteitsvermindering. De (deels) overwonnen barrières zijn als volgt toe te lichten.

Financiën. De initiator geeft aan dat er zonder financiële steun geen systeem van deelauto's van de grond komt. Waar zonneparken na aanleg gereed zijn, blijven deelauto's inzet vergen. Verder zitten mensen altijd met hun oude auto. Er ontbreekt een financiële regeling dat ze een bonus krijgen van de overheid als ze hun oude auto weg doen en elektrisch gaan rijden. Om over te stappen van een eigen auto naar een deelauto, moet een deelauto niet duurder zijn dan een gewone auto. Het mag wel ongeveer gelijk zijn. Het gaat om een optimale bezetting van auto's. De initiator: "In Culemborg willen we inzetten op auto's overdag voor het bedrijf en in de avonden en weekenden voor burgers. Dat is echt een mix." De initiator geeft aan dat de CoöperatieAuto botst tegen het verdienmodel van overheden en marktpartijen: "Als iemand een auto koopt, betaalt die één keer btw en daarna nooit meer, alleen op de brandstof of nieuwe onderdelen na. Als mensen met een deelauto meedoen, blijven ze 5 of 6 jaar gewoon btw betalen." Voor het ontwikkelen van de deelauto-app hebben CoöperatieAuto, NL Lochem Energie en de Hilversumse Energie Transitie coöperaties alle 3000 tot 4000 euro geïnvesteerd. Ook in Duitsland, België en Spanje hebben coöperaties een financiële 
investering gedaan. Van RVO is er voor het vernieuwen van het laadplein subsidie gekregen om het te upgraden. De initiator: "Het hele energienet is straks overbelast. De subsidie voor het laadplein geeft nu een barrière op de E-deelauto-subsidie in verband met een maximumbedrag dat mag worden ontvangen om niet te spreken van staatssteun. Hierdoor kan de coöperatie voor E-deelauto's geen subsidie meer aanvragen voor de komende twee jaar." In het zonnepark zijn 3800 vrijwilligersuren ingegaan. De initiator: "Er was zo'n drang om het neer te zetten, er zat een architect en een goede projectmanager in ons projectteam." De initiator stopt naast eigen tijd ook eigen geld in het initiatief: "Er was 130.000 euro niet gefinancierd. Dat werd uiteindelijk 60.000 euro. Er heeft iemand voor ons voor-geïnvesteerd. In januari 2018 was het helemaal gefinancierd. Ik moest $2 \%$ rente betalen. Maar het is wel gerealiseerd. Het zou mooi zijn als er een soort subsidie was als fonds." Initiatiefnemers lopen grote financiële risico's: "Als wij het zonnepark niet hadden gerealiseerd, moet je alles terugbetalen. We hebben 963.000 euro voor elkaar gekregen. Binnen nu en anderhalf jaar moeten wij 30 deelauto's in de regio wegzetten." De initiator geeft aan dat het moeilijk is om innovaties te financieren: "Voor het zonnepark kreeg ik subsidie, maar niet voor het laadplein. Dat is drie jaar geleden. Ik kreeg de vraag: waar is dat voor nodig? Dat is een barrière voor de innovatie. We wilden voor de troepen uitlopen, we konden het niet gelijk vertalen naar mensen wat het wordt... Nu je resultaat hebt, wordt het gemakkelijker."

Regelgeving. De initiator geeft aan dat twee financiële problemen voortkomen uit regelgeving: regelgeving voor autoverzekeringen en regelgeving voor staatssteun. Dit is als volgt toe te lichten.

- Regelgeving voor verzekeringen. $\mathrm{Na}$ acht maanden heeft de CoöperatieAuto een verzekering kunnen realiseren. "Als coöperatie hang je aan een dun draadje. Een coöperatie in het noorden van het land probeert een verzekering voor elkaar te krijgen bij dezelfde verzekeraar als wij. De verzekeraar stelt nu heel veel gebruikseisen en stopt er anders mee. Als een verzekering wegvalt, ontstaat voor ons een groot probleem. Wij hebben de centrale overheid hiervoor nodig. Als de verzekeraar stopt, dan kunnen we wel met alles stoppen. Daar is hulp van meerdere mensen voor nodig. De coöperaties en het kleine initiatief kunnen dit niet dragen. Dat is de grootste onzekerheid die er nu nog is. Als we geen schade rijden, geen probleem. Als we wel schade rijden, kunnen ze het zo maar stopzetten. Iedere maand betalen de leden van CoöperatieAuto een bijdrage voor de verzekering. Bij te hoge prijzen vervalt het voordeel van E-deelauto's ten opzichte van gewone auto's."

- Regelgeving voor staatsteun. De initiator: "Van regio Rivierenland hebben wij subsidie gekregen voor het laadplein. Daar hebben we 110.000 euro voor gekregen. Nu zijn we meer bezig met de laadauto's. Boven de 200.000 euro is sprake van staatssteun. Als we een dienst van algemeen belang worden, wordt het dan anders met staatssteun? Wij willen geen winst maken, zijn geen bedrijf. Om het te omzeilen, zou je coöperaties moeten splitsen, maar dat is ook niet handig."

Overtuigingen. De initiator is van mening dat hij zelf de grootste barrière voor het initiatief was: "Doel, waarden en kwaliteiten moet je zelf ontdekken. Hoe alles strategisch inzetten? Daar heb ik nu een 9-jarige praktijkopleiding in." Een andere barrière vormt de samenwerking in een driehoek van overheden, markt en coöperaties.

Kennis en relaties. Volgens de initiator was sprake van onbekendheid met het initiatief en onvoldoende kennis bij de wethouder en ambtenaren in 2017, waardoor er geen bijdrage uit het duurzaamheidsfonds van de gemeente kwam om het laadplein te ondersteunen. Later was de wethouder heel blij en trots en heeft het laadplein met zonnepark geopend. De gemeente heeft een projectleider ingezet om alles goed te coördineren bij de gemeente voor alle vergunningen en afspraken.

Relaties zijn belangrijk: overheden kunnen beslissen of zij initiatiefnemers al dan niet toelaten tot netwerken. De initiator hierover: "In de jaren van de GEA (Gelders Energie Akkoord) hebben wij niet aan tafel mogen zitten omtrent mobiliteit, tot twee jaar geleden. Nu hebben wij een opdracht gekregen samen met Lochem Energie voor kwartiermakerschap voor 1000 elektrische auto's. De provincie Gelderland is nu bezig met subsidie. Er wordt geen procesgeld betaald. Wij dienen een aanvraag in. We krijgen $80 \%$ betaald. Als we het realiseren."

Over de bijdrage van de PTRN aan de kennis en relaties van de initiator zegt de initiator: "De PTRN fungeerde voor mij als een praktijkacademie voor het begrijpen en verwoorden van mijn project en 
om het procesverloop van het project te programmeren." Over de positie van de PTRN zegt de initiator: "De PTRN zit bij RVO. Er is geen entiteit. Geen stichting of wat dan ook. Dat mis ik. De PTRN wil het goed doen richting RVO en richting de deelnemers van de PTRN." Binnen de PTRN wordt volgens de initiator een grote afstand tussen adviseurs en doeners ervaren: "Er is maar een klein aantal initiatieven die echt op doen gericht zijn. De rest geeft vooral advies hoe het moet gebeuren, maar doen het niet zelf. Ik heb veel geleerd van de bijeenkomsten van de PTRN. De afstand tussen de denkers en doeners is groot. We zijn met dezelfde doelen bezig, maar: om het in de wijk te zetten. Je moet aan zo veel regels voldoen, dan verzand je. Wij functioneren op lokaal, regionaal, provinciaal, nationaal en EU-niveau. Ik probeer de middelen en de next stap te realiseren. Het zou goed zijn als de PTRN een blijvende financieringsbron krijgt. De PTRN biedt een basis. De PTRN moet dan wel een vrij speelveld kunnen creëren en gevoed worden, financieel. Begin klein in een regio, schaal dat op. Ik doe dat in mijn stad."

Omtrent de (deels) overwonnen barrières kunnen we dus concluderen dat dit regels rond financiën zijn: het jaarlijks blijven betalen van belasting bij een deelauto, het vermijden van staatssteun en regelgeving rond autoverzekeringen. De initiator investeert tijd en geld vooruit, waarbij risico's worden genomen of de financiën nog terugkomen, omdat er van tevoren financieringseisen door anderen worden gesteld. De overtuigingen vanuit overheden en markt domineren nog de overtuigingen om gemeenschap in het algemeen en deelauto's in het bijzonder te bevorderen. Relaties met overheden als de gemeente of provincie zijn vaak cruciaal voor een initiator om een initiatief verder te brengen. De relatie met (en kennisontwikkeling in) de PTRN wordt gewaardeerd. Wel zou de initiator graag een andere status zien voor de PTRN: niet meer RVO-gerelateerd, meer decentraal georganiseerd en gericht op doen.

De verbinding tussen de inhoudelijke en sociale verandering is dat E-Deelauto's nieuwe gebruiksmogelijkheden/vrijheden voor mensen bieden, doordat mensen met meerdere E-deelauto's kunnen rijden. Daarnaast zijn landelijke verbindingen ontstaan tussen E-deel-Coöperaties. Er is veel energie om het initiatief te verspreiden en verbreden, maar er is weinig tijd. De initiator komt aan verspreiden en verdiepen niet toe: middelen om landelijk de kennis te delen en te ondersteunen bij andere Coöperatie zijn niet aanwezig. Wel is de Coöperatie een plek om verder te leren en te experimenteren.

\subsection{Verspreiden, verbreden en verdiepen}

Verspreiding gebeurt door de opschaling tot CoöperatieAuto: andere locaties in Hilversum en Lochem, in samenwerking met Lochem Energie en Hilversumse Energie Transitie, werken samen. Verdere verspreiding gebeurt door mensen die van andere locaties op bezoek komen. Bijna elke week willen mensen komen kijken naar het laadplein. Verder is de CoöperatieAuto kwartiermaker voor 1000 E-deelauto's in Gelderland, samen met Lochem Energie. Ook was er een verkenning voor 1000 deelauto's in de Achterhoek, samen met Lochem Energie. De kwartiermaker: "Sinds de opening van het zonnedak/laadplein aan de Marsmanweg (inmiddels Jan Wolkershof genaamd) krijgt het project veel nationale en internationale aandacht. Zo was het onderdeel van de opening bij het congres 'Hier Opgewekt' voor alle Nederlandse energiecoöperaties in november 2019."

Omtrent de verbreding geeft een kwartiermaker achter CoöperatieAuto aan dat het doel is om het concept in alle 30 regionale energiestrategie Regio's te gaan inzetten. Het streven is om de deelauto in te bedden in regionale RESSEN (Regionale Energiestrategieën). "Mogelijk wordt CoöperatieAuto dan gesplitst in CoöperatieAuto NL of Centraal, en een CoöperatieAuto Rivierenland oprichten en $30 \mathrm{x}$ CoöperatieAuto in RESSEN? Dat zou mooi zijn. In iedere RES een coöperatieauto... verbonden met alle regio's en dan ben je zelf de spil." Andersom: energie die overblijft van windenergie voor deelauto's inzetten. "Mensen krijgen hier $10 \%$ van de windmolens, wat dan overblijft is voor algemeen nut. We kunnen windmolens inzetten voor deelauto's; dat is in Waterland gebeurd." Het idee kan ook op de $\mathrm{P}+\mathrm{R}$ 's bij stations en op parkeerterreinen bij winkelcentra worden gerealiseerd (is nog niet gebeurd). "We realiseren deelauto's met maatschappelijk geld. Je hebt energie samen en mobiliteit samen. We zouden het ritdelen kunnen gaan invoeren. Mensen met elektrische auto's laten meerijden. Elektrisch 
autorijden is een tussenfase. Je kunt mensen meenemen bij een hub. Bij snelwegen gaan hubs komen, een hubstation (auto's en treinen zijn beide elektrisch)."

CoöperatieAuto wil op de volgende manieren vormgeven aan verdieping:

- Doorontwikkelen van het laadplein voor meer capaciteit en doorontwikkelen van digitale cloudboxbakjes in E-deelauto's vanwege aanpassingen in G-netwerk en slimme laadmogelijkheden met E-deelauto's;

- Verder uitdenken van een E-hubstation waarbij alle verkeersmodaliteiten elektrisch zijn;

- Nagaan hoe bedrijven en organisatie kunnen aansluiten om een bijdrage te leveren met E-deelauto's aan de klimaatdoelstellingen;

- Nagaan hoe overheden kunnen stimuleren dat het voor burger en organisatie aantrekkelijk wordt om mee te doen aan E-deelauto rijden.

\subsection{Aanjaagmechanismes}

Achter CoöperatieAuto gaat een drijvende kracht schuil. Hij heeft met andere mensen en andere organisaties tastbare resultaten geboekt die nu nieuwe energie genereren. Vanuit andere coöperaties zoals Rivierenland en vanuit de PTRN wordt door de initiator veel energie ervaren om door te gaan met deelauto's en het te verspreiden, te verbreden en te verdiepen. De initiator komt aan verspreiden en verdiepen niet toe. De middelen om landelijk de kennis te delen en te ondersteunen bij andere coöperaties zijn niet aanwezig (energizing). Met het nieuwe slimme laadplein als idee wordt al geëxperimenteerd in Lombok in Utrecht. De techniek met de app staat niet stil, die blijft zich doorontwikkelen. De cloudbox kan communiceren met de auto en met de app. De cloudbox was afgestemd op 3G. Dat wordt nu uitgefaseerd. Daar heeft de CoöperatieAuto last van: ze moeten vernieuwen vanwege voortschrijdende digitale ontwikkelingen naar $4 G$ en $5 G$ (experimenteren). Het laadplein met zonnepanelen en de E-deelauto's en de app hebben een grote uitstraling. Er komen veel mensen op af die hetzelfde op andere locaties willen ontwikkelen (logic of attraction).

Bijna elke week willen mensen komen kijken naar het laadplein om na te gaan hoe dit is gerealiseerd (olievlekwerking). De deelauto is het middel om de mensen te laten samenwerken rond klimaatdoelen uit het Klimaatakkoord (verbinden). Omtrent robuustheid: enerzijds zijn er klinkende resultaten geboekt, anderzijds blijft er onzekerheid omtrent de institutionele inbedding: het verzekeren van E-deelauto's en het financieren van nieuwe ontwikkelingen waarbij subsidies of fondsen nodig zijn, omdat initiatiefnemers anders grote financiële risico's lopen. 


\section{Tafeldemocratie van de Vereniging Noorden Duurzaam in drie pilots}

\subsection{Introductie}

De Vereniging Noorden duurzaam is een vereniging van personen, organisaties, netwerken en overheden in Noord-Nederland die willen werken aan een duurzame economie en samenleving. Het hele idee van de tafeldemocratie is tien jaar geleden in gang gezet met een project voor de betonketen in Groningen. De Vereniging Noorden Duurzaam is georganiseerd als een netwerk van vier soorten 'tafels': thematafels voor kennisgemeenschappen, sectortafels voor de sectorale dimensie, ketentafels waarin thematafels en sectortafels circulair samenwerken en gebiedstafels waar alle tafels van een regio, gemeente of wijk als een parlementaire kamer samenkomen. De spelregels van dit tafelnetwerk zijn anders dan in de representatieve democratie. Zo is er geen kiesdrempel, maar beslist een gebiedstafel democratisch over toelaten van nieuwe tafels. Het criterium daarbij is dat een nieuwe tafel niet overlapt met bestaande tafels van dezelfde soort binnen hetzelfde gebied, en dus een unieke vertegenwoordiger van een achterban is. De Vereniging Noorden Duurzaam heeft met de tafeldemocratie in drie pilots geoefend.

\subsection{Herkennen en identificeren van small wins}

De Vereniging Noorden Duurzaam wil de duurzaamheidstransitie versnellen door 'de kleine stap' van de tafeldemocratie, een nieuwe visie op democratie en politiek, in eerste instantie via omvorming van wijk- en dorpsraden of via een aanvulling op gemeenteraden. De kleine stap is eigenlijk een relatief grote stap: want al sterk formeel en institutioneel van aard, wat kan verklaren waarom dit initiatief moeilijk in praktijk is te brengen. De tastbare resultaten zijn nog beperkt. De Vereniging Noorden Duurzaam heeft een werkmodel voor tafeldemocratie ontwikkeld voor wijkraden, waarbij een aanvullende parlementaire kamer wordt ingedeeld in vijf 'taakvakken': burgernetwerken, kennisnetwerken, voorzieningenkoepels, bedrijvenbranche en overheden. Het is in augustus 2019 getoetst bij PTRN/DD, en in november 2019 in Heerlen-centrum met mensen die een energiecoöperatie willen opstarten (via contact PTRN) en ze werken aan de voorbereiding van een test in Wieringermeer in Noord-Holland.

De tafeldemocratie beoogt een diepgaande verandering. Tafeldemocratie wordt bedoeld als concept voor bestuurlijke vernieuwing, gericht op duurzame ontwikkeling. Het beoogt een functioneel democratische aanvulling op de partij-democratische inrichting van parlementen op nationaal, provinciaal, gemeentelijk en ook wijkniveau. Het stelt in die aanvulling taakverdeling boven partijenconcurrentie, vergelijkbaar met het bestuurssysteem van de waterschappen. Van dit model wordt verwacht dat dit een andere en meer coöperatieve overlegcultuur van coalitievorming en machtsdeling, en ook van oppositievoering en conflictbeheersing, zal veroorzaken.

De (deels) overwonnen barrières zijn als volgt toe te lichten:

Financiën. Volgens de initiator kan de tafeldemocratie bedreigend overkomen voor huidige gemeenteraden en huidige wijkraden, omdat de andere samenstelling ook andere financiële verhoudingen geeft: "Sommige ambtenaren hebben een aanzienlijke persoonlijke invloed als het gaat over besteding van financiële middelen in wijken. Daardoor kunnen voorstellen voor tafeldemocratie ook te maken krijgen met ambtelijke weerstand. Dit maakt het belangrijk om niet alleen contact te hebben met ambtenaren, maar ook met bestuurders, raadsfracties en wijkraden." 
Geld vinden voor campagnes gaat bij tafeldemocratie in stappen:

1. bij deelnemers verzamelen van kwesties die campagneaanpak vergen en deze prioriteren.

2. Vragen aan de vijf taakvakken wat ze kunnen bijdragen aan de campagne en dan verbindingen maken. De initiator hierover: "Als jullie dit doen, dan kunnen anderen dat ermee. Er ontstaat dan synergie en energie. Deelnemers voelen dan: dit kan wel eens werken."

3. Verzamelen van onderbouwende cijfers. Cijfers zijn nodig om de proportie en de trend van kwesties aan te geven ('het is niet best en het wordt steeds erger') en om kosten en opbrengsten van campagnes inzichtelijk te maken. De initiator: "Burgers kan je niet vragen om met geld aan te komen. Bedrijven kunnen aan sponsoring doen. Overheden zijn de belangrijkste financiers."

Regelgeving. Gemeenten spelen volgens de initiator een belangrijke rol bij het aanjagen van democratische experimenten, maar willen ook vaak de regie houden. In de gemeente Groningen zijn enkele jaren geleden in vijf wijken experimenten met nieuwe democratie gestart, soms in samenwerking met Rijksuniversiteit Groningen (RUG). Er is actief gemeentebeleid op gezet, met ondersteuning. De gemeente wil in die experimenten bijvoorbeeld een deel van het geld dat ze toch besteden in de wijk via de wijkraad laten lopen. Dat heet een wijkdeal. In een andere wijk is een coöperatieve wijkraad ingesteld: voor de helft gemeenteraadsleden en voor de andere helft ingelote burgers uit de wijk. Weer ergens anders is er een wijkbedrijf opgezet. De experimenten gaan echter op punten als representativiteit, democratisch zelfbestuur of transitiepotentieel vaak minder ver dan wat beoogd wordt met tafeldemocratie. Dit zou een nieuw experiment rechtvaardigen, maar het kost veel tijd en overleg om daar ruimte voor te krijgen. De initiator: "Voor ons is ook hierom rechtstreeks contact met wijkraden belangrijk. Die kunnen een eigen plan trekken. Wijkraden worden niet bepaald door de Kieswet. Een wijkraad herinrichten is eenvoudiger dan een tweede kamer van de gemeenteraad instellen". De initiator geeft met dit voorbeeld aan dat het moeilijk is om als initiatief te voldoen aan de regels die vanuit een gemeente aan een innovatief initiatief worden gesteld.

De tafeldemocratie is geen vervanging van partijendemocratie, maar een aanvulling hierop. Dus moet je het volgens de initiator inbedden tussen bestaande instituties, zodat het tot een bijdrage aan transitieregie in staat is. Dat een tafeldemocratie eigen regels meeneemt waarmee bestaande instituties akkoord dienen te gaan, is misschien mede een reden dat velen het als een brug te ver zien. De initiator over deze regels voor de tafeldemocratie: "Organiseer het wel echt parlementair: laat zien dat je naast de politiek komt te staan en niet eronder. Er moet een onafhankelijke voorzitter bij, een griffier die voor een openbaar archief zorgt, een publieke tribune, pers moet deel kunnen nemen. Geen bestuur, maar een presidium zodat je duidelijk een parlementaire positie claimt. Je wordt een 'Tweede Kamer' van de gemeenteraad. De gemeenteraad is nodig om deze kamer te legitimeren."

Overtuigingen. De initiator heeft veel overtuigingen die tonen dat tafeldemocratie leidt tot bestuurlijke vernieuwing. De initiator: "Een gebiedstafel, of transitiekamer, is geen achterkamer: je gaat naar transparantie. Onder maatschappelijke transitiedruk gaat het debat anders verlopen als je je dient te verantwoorden naar andere maatschappelijke sectoren. Transparantie en openbaarheid maken dat partijen niet zomaar weg kunnen blijven. Transparantie en openbaarheid zijn naar verwachting belangrijke hefbomen. Of dat echt zo werkt, zal uit testsituaties moeten blijken."

De initiator geeft aan dat tafeldemocratie er niet toe leidt dat de ene actor vanuit overtuiging de andere actor kan voorschrijven wat die actor moet doen. De initiator: "Bij de evaluatie van een van de testsituaties (een rollenspel) gaf een deelnemer aan er zoals gebruikelijk op uit te zijn geweest om als bewoners (een taakvak) tegen de politiek zeggen wat ze moeten doen, maar dat dat niet werkte, omdat andere taakvakken erop aandrongen dat de bewoners ook zelf zouden bijdragen aan een gezamenlijke campagne voor duurzaamheid. Dit werd opmerkelijk gevonden: het biedt nieuw perspectief op politieke samenwerking op lokaal niveau voor duurzaamheidsvisie. De taakverdeling is cruciaal hierin. Een nuttige taakverdeling hangt af van de inrichting van het overleg. De vijf taakvakken zijn afhankelijk van elkaar en zijn alle onmisbaar bij duurzaamheidstransitie. Er is op dit metaniveau onderling geen concurrentie. De taakvakken representeren de samenleving als geheel. Dat maakt dat je het kan gebruiken als grondmodel voor een wijkraad of voor een 'Derde Kamer'." 
De initiator heeft de overtuiging dat inhoudelijke vernieuwing bestuurlijke vernieuwing vereist (ook vanuit de small wins-benadering wordt met de barrières aangegeven dat bestuurlijke kaders belemmeringen kunnen vormen om initiatieven verder te brengen): "Er is dringend behoefte aan brede, maatschappelijke samenwerking om grote, complexe duurzaamheidsdossiers aan te pakken zoals circulariteit, emissies en inclusiviteit. Solidariteit tussen de onderling afhankelijke blokken van de burgers, de kennisnetwerken, de voorzieningen, de bedrijven en de overheden is daarbij belangrijker dan coalitievorming tussen de eeuwig concurrerende linkse en rechtse partijen. Deze vijf blokken moeten we aanduiden als taakgroepen, niet als belangengroepen, want het gezamenlijke belang overstijgt het individuele belang. Groepsdruk tussen deze blokken is een hefboom die benut moet worden om voorzitters van koepels te bewegen niet alleen hun achterban te volgen, maar daar ook vanuit maatschappelijk belang leiding aan te geven." De initiator geeft het RES als voorbeeld waar de inhoudelijke vernieuwing niet gepaard is gegaan met bestuurlijke vernieuwing en waar volgens de initiator veel discussie ontstaat over positiespel tussen actoren: "Ook bij RES is de samenstelling van overlegorganen belangrijk. Zonder a-priori-indeling in taakvakken ontstaat ook daar geen nieuwe krachtenverhouding. Ook hier kan het taakvakkenmodel van de gebiedstafel van pas komen, waarbij de invulling van de vakken per RES kan verschillen. Het model lijkt misschien formalistisch, maar het legt een basis voor taakverdeling en samenwerking die er anders niet is. Het brengt iedereen in een minderheidspositie en maakt de vakken afhankelijk van elkaar, wat goed is. De onderlinge verhoudingen zijn in de RES nu niet geregeld. Dan gaat veel energie op aan positiespel." De initiator heeft de overtuiging dat tafeldemocratie werkelijk iets nieuws te bieden heeft: "Tafeldemocratie komt niet in de plaats van partijdemocratie, maar vult deze aan. Er zijn al burgertoppen, G1000, maar die betrekken alleen burgers, en dan doorgaans de burgers die toch al actief waren. Kennisnetwerken, voorzieningen en bedrijven zijn hier als maatschappelijke blokken niet bij betrokken. Het zijn in feite verbeteringen in de inspraak in de partijendemocratie, en geen instrument voor transitietaakverdeling." Aan de hand van het voorbeeld Wieringermeerpolder toont de initiator zijn overtuiging dat partijen die nu buiten schot blijven in de democratie, met de tafeldemocratie wel medezeggenschap hebben: "We zitten in de aanloop naar een test in de Wieringermeerpolder. Als dat doorgaat, wordt het een test op wijkniveau, want de polder is een wijk. Er is daar spanning tussen de overheid, de bewoners en de multinationals die zich in de polder gevestigd hebben. In de gemeenteraad is een gebiedsplan met 25 tegen 1 afgewezen en moet het overleg opnieuw worden gedaan. Dat kan wellicht in de vorm van een gebiedstafel, waarbij alle partijen aan tafel kunnen komen. Wieringermeer is van oudsher grootschalig ingericht. De menselijke maat komt nu echter in het gedrang, met de ontwikkeling van een mega windpark, industriële glastuinbouw en enorme datacenters van Microsoft, Google en Amazon die stroom van het windpark afnemen. De agrariërs maken zich zorgen over grondprijzen. De bewoners maken zich zorgen over de leefbaarheid en het erfgoed van de polder. Twee maanden terug hebben de boeren de wegen geblokkeerd uit protest. In dat conflict zeggen alle partijen: we hebben belang bij een nieuwe vorm van overleg. Want in de gemeenteraad hebben de dorpsverenigingen, de voorzieningen van de polder en LTO-Noord geen stem en kunnen ook Vattenfall en Microsoft hun mvo-beleid niet toelichten. Hier is ruimte voor bestuurlijke vernieuwing, voor een nieuwe werkvorm voor lokale politiek."

De representativiteit van wijkraden en hun democratische verantwoording is volgens de initiator niet altijd optimaal: "Soms hebben vrijwilligers door hun inzet een invloedrijke positie opgebouwd en hebben ze voor een meer democratische werkwijze niet altijd belangstelling."

Middelen. De tafeldemocratie is alleen toegepast in testsituaties: verkenningen, try-outs. Er is nog geen wijkraad of gemeenteraad die het model heeft geadopteerd. Wel is de Vereniging Noorden Duurzaam begonnen met presentaties te maken om de dialoog met wijkraden te kunnen voeren. Dat heeft de Vereniging Noorden Duurzaam nog net niet bereikt. De initiator: "Het ligt allemaal vrij gevoelig. Bij wijkraden moet je eerst lang investeren in relaties. Er moet vertrouwen zijn." Met de tafelatlas als communicatiemiddel wil de Vereniging Noorden Duurzaam laten zien hoe het transitielandschap eruitziet. De initiator: "Er zijn al veel websites die overzicht bieden over een aspect van transitie. We proberen hier transitie als geheel te vangen, ook het politieke niveau. Het positioneert de gebiedstafel als een cruciaal orgaan voor transitie en als representant van de lokale samenleving, door alle partijen die niet vertegenwoordigd zijn toch een plaats te geven." 
Kennis en relaties. De Vereniging Noorden Duurzaam doet de kennis zowel binnen als buiten de PTRN op. De PTRN speelt een zeer belangrijke rol voor de pilots. De contactpersoon uit de Vereniging Noorden Duurzaam is heel positief over de PTRN: "Het lijkt misschien dat de PTRN minder resultaat heeft opgeleverd dan op voorhand gedacht werd. Maar er is zo ontzettend veel geleerd! De werkwijze om stapsgewijs vanuit vier werelden naar herhaalbare prototypes en small wins te werken, is daar bedacht. Onderzoek maar eens welke andere gestructureerde werkwijzen er bestaan voor brede samenwerking aan transities. Tel je zegeningen met de PTRN." De Vereniging Noorden Duurzaam heeft voorgesteld om regionale en lokale varianten van de PTRN als transitieverzamelpunt te ontwikkelen. Dat kan een vervolg op de PTRN zijn. [Dit idee is op de digitale samenwerkingsruimte geplaatst. Hier hebben twee mensen positief op gereageerd, de rest nog niet. Misschien is eerst een verder (digitaal) kringgesprek nodig voordat mensen zich durven uit te spreken in een richting.]

Tijdens een werklunch in december 2019 is met drie mensen over macht en manipulatie rond tafeldemocratie gesproken: een oud-burgemeester, een directeur van een IT-securitybedrijf en een bestuurder van een regionale vakbond. Hun stelling: als het te manipuleren is, zal dat ook gebeuren. $\mathrm{Zij}$ vonden de tafeldemocratie een goed model voor het voorbereiden van transitiebeleid. Zij vonden de besluitvorming beter in elkaar steken dan bij normale politieke circuits. Wel zou één taakvak door samenwerking met twee andere vakken de resterende twee vakken kunnen domineren. De kans daarop wordt echter beperkt geacht, omdat er dan binnen drie vakken een meerderheid voor dat opzetje zou moeten zijn. In het bedrijvenvak bijvoorbeeld kan dat al lastig zijn met representanten van zowel het grootbedrijf als het mkb en de zzp'ers.

Omtrent de (deels) overwonnen barrières kan worden geconcludeerd dat veel barrières nog voortbestaan. De tafeldemocratie wil een andere verdeling van financiën dan onder de huidige bestaande instituties. Daar zit ook een deel van de weerstand tegen tafeldemocratie. Het is voor de initiator moeilijk om met de tafeldemocratie als initiatief te voldoen aan de regels die vanuit een gemeente aan een innovatief initiatief worden gesteld. Dat een tafeldemocratie eigen regels meeneemt waarmee bestaande instituties akkoord dienen te gaan, is misschien mede een reden dat velen de tafeldemocratie als een brug te ver zien. De initiator heeft veel overtuigingen die tonen dat tafeldemocratie leidt tot bestuurlijke vernieuwing en het toont de spanningen met bestaande instituties. Inhoudelijke vernieuwing vergt volgens de initiator ingrijpende bestuurlijke vernieuwing. De PTRN heeft voor de tafeldemocratie een zeer belangrijke rol gespeeld om barrières te overwinnen, bijvoorbeeld door pilots mogelijk te maken. Geopperd is om meer met lokale en regionale varianten van de PTRN te werken.

De tafeldemocratie beoogt een verbinding van een inhoudelijke en sociale verandering. De tafeldemocratie is afgeleid van ketenprojecten in de bouw. De ketenprojecten in de bouw waren als startmotor bedoeld om het proces met overheden, burgers en bedrijven aan te jagen. Vanuit energie breder willen trekken naar mobiliteit, voedsel, zorg, wonen et cetera is nog maar gedeeltelijk gelukt. Niet dat men niet wilde verbreden of leren. Het is heel veel werk en men kwam daarmee aan een gestructureerd leerproces onvoldoende toe - is leerpunt an sich: niet alles tegelijk.

Via de website worden mensen uitgenodigd om een tafel(netwerk) te starten dan wel zich aan te sluiten bij een bestaand netwerk. Levendigheid van het eigen tafelnetwerk van de vereniging is beperkt, nadat in 2017 door een heroriëntatie de begeleiding afnam en veel tafels gestopt zijn. De focus werd verlegd naar conceptontwikkeling voor gebiedstafels, bedoeld als democratische verzamelpunten voor bestaande netwerken. In 2018 is de tafelatlas ontwikkeld, gevolgd door het taakvakkenmodel in 2019. De kaarten in de atlas schetsen volgens de vereniging een toekomstbeeld van openbaar bestuur met daarin de gebiedstafel als nieuw parlementair orgaan. Deze beeldvorming is bedoeld om debat, leren en nieuwe experimenten te bevorderen. De kaarten van onder andere Nederland, Noord-Nederland, gemeente Groningen en de Wieringermeer zijn daartoe gevuld met redactionele vermeldingen van bestaande netwerken. Het is onduidelijk in hoeverre de website een plek is met energie om verder te leren en experimenteren. 


\subsection{Verspreiden, verbreden en verdiepen}

Vanuit de Vereniging Noorden Duurzaam is op verschillende manieren geprobeerd het initiatief van de tafeldemocratie te verspreiden: via contact met een aantal wijkraden in Groningen, Hoogkerk en Vinkhuizen en Lewenborg. Verder lopen er gesprekken met Politieknetwerk Drenthe. Die hebben belangstelling voor de toepassing voor de dorpsraden. Een adviesbureau dat werkt voor gemeenten heeft belangstelling getoond voor het concept tafeldemocratie. Zij willen verder verkennende gesprekken voeren. Ook andere bureaus willen bijdragen aan transities. De initiatiefnemer: "We kunnen dit niet zelf overal toepassen. Vandaar een opensourcemodel. Dat betekent vrije verspreiding onder voorwaarde van bronvermelding." Tot slot doet een hoogleraar in Zuid-Afrika vergelijkbare dingen omtrent vraagstelling, maar met een totaal andere aanpak. Ze gaan reflecteren op elkaar. Voor verbreding probeert de Vereniging Noorden Duurzaam iets te ontwikkelen dat schaalonafhankelijk is: van wijkniveau tot internationaal. Verder valt er volgens de initiatiefnemer nog heel wat te verdiepen: "De tafeldemocratie is een model met vijf taakvakken. We willen een modelstatuut voor een gebiedstafel, dat formeel is opgesteld met toe- en uittreding. Hoe wordt er gestemd, hoe verloopt de besluitvorming? Naar een uniform model of niet? Een andere verdieping is: hoe verloopt binnen een taakvak van tafeldemocratie de vertegenwoordiging en verantwoording richting achterbannen? Je kunt een seniorenplatform hebben of hobbyclubs. Hoe ga je om met overlappende vertegenwoordiging?" Er is volgens de initiatiefnemer ook nog verdieping mogelijk op identiteit: op waardenniveau mensen verbinden via tafeldemocratie.

\section{Aanjaagmechanismes}

Er wordt vanuit de Vereniging Noorden Duurzaam energie gestoken in het theoretisch doordenken van het model van de tafeldemocratie. De PTRN speelde een zeer belangrijke rol in het bieden van testlocaties voor het model van de tafeldemocratie (Energizing). Het echte toepassen is nog niet gebeurd (experimenteren). De Vereniging Noorden Duurzaam ziet graag dat leerproefsituaties zich aandienen, die professioneel begeleid kunnen worden vanuit de Vereniging Noorden Duurzaam dan wel door vakgenoten. Verondersteld wordt dat als er cases zijn, die op hun beurt dan wel weer aandacht genereren bij wijkraden, gemeenten etc. Er zijn naast pilots nog geen praktijken waar het gedachtegoed van de tafeldemocratie integraal is toegepast (logic of attraction ontbreekt). Met onderdelen daarvan is wel praktijkervaring opgedaan, in enkele tientallen regionale thematafels, sectortafels en ketentafels. Met de voorloper van het concept van een tafel-democratische gebiedstafel is in 2017 een experiment gedaan in de (toenmalige) gemeente Haren. Er lopen contacten met de gemeente Groningen en een aantal wijkraden in Groningen om tafeldemocratie toe te passen. Verder lopen er gesprekken met Politieknetwerk Drenthe. Die hebben belangstelling voor de toepassing van het model voor tafeldemocratie voor de dorpsraden. De Vereniging Noorden Duurzaam heeft verder contact met een adviesbureau dat werkt voor gemeenten. Zij willen verder verkennende gesprekken voeren. Ook zijn er gesprekken met bureaus die willen bijdragen aan transities. De Vereniging Noorden Duurzaam kan het model van de tafeldemocratie niet zelf overal toepassen. Vandaar dat zij werken met een opensourcemodel (een Creative Commons By-Sa licentie: hergebruik is vrij onder voorwaarde van bronvermelding en mits verspreiding van varianten onder dezelfde licentie is) (olievlekwerking). Wat het verbinden betreft: de Vereniging Noorden Duurzaam wil meer de academische wereld bij het model van de Tafeldemocratie betrekken. Laat onderzoek lopen naar de incubatie van dit project en zet het multidisciplinair op. Kijk niet alleen naar duurzame ontwikkeling, maar ook naar politicologie, sociologie, bestuurskunde, staatskunde. Er is verder contact met iemand in Zuid-Afrika die een vergelijkbare probleemstelling volgt, alleen bij de uitwerking wijken ze fors van elkaar af: voer voor discussie en inspiratie. Het model van tafeldemocratie is als model robuust, maar nog niet in de praktijktoepassing. 


\section{$7 \quad$ Toogdialoog van Organisatie Lijnspel om Flitscoöperatie (energie) voor Heerlen-Centrum op te richten}

\subsection{Introductie}

Het college van Burgemeester en Wethouders van Heerlen wil dat een breed gedragen 'energiecoöperatie Heerlen-Centrum' de daken in het centrum van de stad zo veel mogelijk gaat voorzien van zonnepanelen. Op die manier draagt het gemeentebestuur bij aan de uitvoering van ambitie 23 uit het Bidboek Urban Heerlen: 5000 zonnepanelen in Heerlen-Centrum. Organisatie Lijnspel ondersteunde de gemeente hierbij. Dit Heerlense bedrijf is gespecialiseerd in de begeleiding van coöperatieve werkvormen op maatschappelijk gebied en is in staat bewoners te betrekken en te motiveren. Lijnspel nam het initiatief om huiseigenaren, pandbezitters, ondernemers en bewoners in het centrum bij elkaar te brengen en enthousiast te maken voor het idee. Samen beslisten zij vervolgens welke vorm de coöperatie kreeg, welke doelen zij zichzelf stellen en welke voordelen daar eventueel tegenover staan. De coöperatie kreeg de naam: flitscoöperatie. Tijdens de bijeenkomsten werd de zogenaamde Toogdialoog ingezet: een bijeenkomst die 2 tot 2,5 uur duurt en uit drie stappen bestaat: 1) kennis delen en afstemmen, 2) in praktijk toepassen wat je hebt geleerd in een casus waar je mee bezig bent (incl. dilemma's) 3) toogdialoog: uit de ruimte weggaan, op café, aan de bar in informele setting verder praten. Het werken volgens deze methode heeft volgens de initiator als voordeel dat je elkaar veel beter leert kennen: "Iemand vertelt iets over deelauto's. Mensen die 70+ zijn zeggen hier niets over. Gaan later bij elkaar staan: dit en dat kan niet. Er komen twee jonge mensen bij staan. Die auto staat ergens dicht bij hun huis en ze kunnen er mee naar hun kleinkinderen etc. Er ontstaat leren tijdens dialoog. We voren dit co-spel consistent door: 1) kennis delen, 2) samen aan werken en 3) afsluiten met een drankje en de hoofdvraag: wat kunnen we hier nu verder mee?"

\subsection{Herkennen en identificeren van small wins}

De kleine stap bestaat uit de ondersteuning vanuit de Organisatie Lijnspel van de gemeente Heerlen via het organiseren van een dialoog met de oprichting van een energiecoöperatie voor Heerlen-

Centrum. De tastbare resultaten worden door de initiator als volgt verwoord:

1. Poging en betrokkenheid van de groep in Heerlen. De initiator: "Wat ik heb geleerd in de PTRN heb ik meegenomen. Ik injecteer kennis van buiten in het kiemgebied. Iedereen komt kennis brengen tot zo ver je kan gaan."

2. Gelijkheid in kennis. Groep bestaat uit mensen uit kennisdomein, procesdomein en leef- en systeemwereld, ofwel verschillen in organisatiedomein. Iedereen heeft zelfde bagage in rugzak.

3. Bewustzijn van verantwoordelijkheid die burgers moeten nemen.

4. Gemeente heeft veel daken en stelt er 2 tot 3 beschikbaar in badges van 150 per meter. De initiator: "We hebben 17 daken nodig. Dat is de volgende winst die aan het opstarten is. Die bewustwording zit niet in behoefte om te investeren, maar wel als adoptie van het zonnepanelenproject leidt tot een korting op de energierekening en tot zeggenschap over leefbaarheid en veiligheid en zeggenschap over organiseren van activiteiten, dan krijgt het een geheel andere dynamiek. Iemand op leeftijd moet ook gemakkelijk weer kunnen uitstappen. Als je stopt, moeten anderen er weer in kunnen stappen."

5. De PTRN heeft 3 kiemregio's aangewezen, één ervan is Parkstad (Heeg en Wieringermeer zijn de andere kiemregio's). De aanwijzing leidt tot samenwerking met de gemeente en tot een regiodeal. Er ontstaat door het benoemen door de secretaris en voorzitter van de PTRN een belangrijke motivatie tot samenwerking voor de Flitscoöperatie en de gemeente Heerlen. 
De diepgaande verandering bestaat uit het betrekken van meer mensen bij duurzaamheidsthema's, wat tot meer verantwoordelijkheid leidt. Meer partijen krijgen zeggenschap op leefbaarheid. Dat levert een andere dynamiek op. De (deels) overwonnen barrières zijn als volgt toe te lichten:

Financiën. De gemeente Heerlen speelt bij het opzetten van de energiecoöperatie een belangrijke bevorderende rol door het proces te faciliteren en financieren, waarmee kennis kon worden ingehuurd van bijvoorbeeld andere PTRN-leden. Met de gemeente is verder afgesproken dat de energiecoöperatie - en daarmee energie - het financieringsmodel wordt voor lokale voorzieningen, zoals een speeltuin of sportvereniging. Via een energiecoöperatie kan iedereen deelnemen, ongeacht de persoonlijke financiële situatie of gunstige positie van een dak voor de zon.

Regelgeving. Via een van de leden van de PTRN ontstond het idee voor de opzet van een flitscoöperatie. Er werkt iemand in Aken en die zei: "Ik ga met jullie twee sessies beleggen hoe het allemaal werkt: SDE+ postcode roos." Er ontstond een groep van 7 mensen uit een groep van 35 mensen en die bracht het weer terug naar een grotere groep. Voor de flitscoöperatie zijn statuten geformuleerd die bij een notaris passeren. Regelgeving werkt hier dus in bevorderende zin. Juridisch vormt de aanleg van zonnepanelen op daken wel een belemmering. Met 80 verschillende eigenaren van onroerend goed in de stad is het onmogelijk om collectief panelen te kunnen leggen.

Overtuigingen. Het initiatief voor het instellen van een flitscoöperatie gebeurde vanuit de overtuiging dat bij de energie- en klimaattransitie de mindset om moet. De energie- en klimaattransitie is nog vooral vanuit Brussel ingegeven en zijn er maar weinig mensen mee bezig. Energie biedt een podium om zelfsturing mogelijk te maken. De groei van aantallen coöperaties of de verdere verbreding van thema's waar coöperaties zich mee bezighouden, bevorderen het leggen van regie bij burgers: "Hoe meer dat als kiemen in de samenleving gaat ontstaan, hoe sneller de nieuwe rollen tot stand gaan komen." De overtuigingen van de gemeente Heerlen en van de flitscoöperatie komen overeen. Dit komt, omdat de flitscoöperatie mede op initiatief van de gemeente Heerlen is ontstaan.

Middelen. De organisatorische opdeling van thema's in domeinen bij de gemeente bemoeilijkte de voortgang van het initiatief: "Voordat wij in contact waren met de domeinen en het sociale domein in contact kunnen brengen met het domein vastgoed, waren we een jaar verder binnen dezelfde gemeente."

Vanuit het initiatief werd ook last ervaren van sommige politieke partijen: "Sommige partijen zijn tegen alles. Dat kost veel tijd en energie. Het zit vooral in de personen zelf. Figuren die op het pluche zitten, willen niet weg en hebben vaak verstokte beelden. Het gaat hierbij uiteindelijk over macht. Je overwint het door zelf ook politiek te bedrijven. We gaan eerst ons idee uitleggen. Voorbespreken met mensen in de raad. Je wordt wat slimmer." De gemeente heeft ook daken beschikbaar gesteld aan de coöperatie. Qua samenwerking en cultuurverschillen wordt vanuit het initiatief nogmaals aangegeven dat je niet te snel moet willen gaan vanuit je initiatief en wordt de gemeente vergeleken met het principe van het slaan van een paaltje in bevroren grond: "langzaam op slaan, anders breekt het paaltje. Het paaltje gaat langzaam steeds dieper in de grond. Voor een besluit moet je minstens een halfjaar uittrekken."

Kennis en relaties. De initiatiefnemer geeft aan dat er via de PTRN ook ideeën zijn ontstaan om in Heerlen een Voedselraad op te zetten. De initiatiefnemer geeft aan dat de stadsregio in Heerlen (Parkstad) al bezig was met het opstellen van een programma, dat niet verder komt dan te downloaden documenten. Via intrinsieke waarde van leraren of ouderverenigingen zijn stappen te zetten.

De initiatiefnemer ervaart de PTRN als echte familie, waarbij iedereen voor elkaar klaarstaat. Opheffen van de PTRN kan betekenen dat de familie uit elkaar valt. Omtrent de resultaten die de PTRN tot nu toe heeft bereikt, is een te negatieve interpretatie volgens de initiatiefnemer niet op zijn plaats. De resultaten zijn de eerste sporen van kanteling, waarbij het er volgens de initiatiefnemer om gaat wat je er zelf mee gaat doen. 
Geconcludeerd kan worden over de (deels) overwonnen barrières dat de gemeente Heerlen een bevorderende rol speelde door het proces te faciliteren en te financieren. Ook heeft de gemeente aangezet om lokale publieke en private voorzieningen te financieren uit energie. Regelgeving is bevorderend ingezet: voor het vastleggen van de statuten. De overtuigingen van de gemeente Heerlen en van de flitscoöperatie komen overeen. Dit komt omdat de flitscoöperatie mede op initiatief van de gemeente Heerlen is ontstaan. De organisatorische opdeling van thema's en dossiers binnen het ambtelijk apparaat en de verschillen in politieke partijen waren belemmerende factoren. De relaties en kennisdeling met de PTRN is bevorderend geweest. Al met al hebben de gemeente Heerlen en de PTRN het initiatief vooral bevorderd en hier en daar is het initiatief vanuit de gemeentepolitiek deels belemmerd.

De verbinding tussen de inhoudelijke en sociale verandering ontstond doordat de organisatie Lijnspel initiatief nam om huiseigenaren, pandbezitters, ondernemers en bewoners in het centrum bij elkaar te brengen en enthousiast te maken voor zonnedaken. Zij zetten ook een beslisstructuur op voor de vorm van de coöperatie en de verdeling van winst uit energie. De nieuwe coöperatie in oprichting bruist van de energie. Er zijn plannen in de maak waar ze zo 1,5 jaar mee vooruit kunnen en is daarmee een plek met energie om verder te leren/experimenteren.

\subsection{Verspreiden, verbreden en verdiepen}

De Toog Dialoog als methode is verder uitgedragen (verspreiden) naar bijvoorbeeld Heeg en naar Food Council Metropool Regio Amsterdam. De gemeente Heerlen wil graag verspreiding zien naar andere wijken van Heerlen: "De eerste stap is 5000 zonnepanelen. Het moet eigenlijk naar 25.000 panelen gaan. Als het model draait in centrum Heerlen kan het ook draaien voor een wijk in Heerlen." Verder wil men het financieel model verspreiden bij sportverenigingen en carnavalsverenigingen. Omtrent verbreding worden de volgende mogelijkheden bekeken: "We zijn in contact met 'deel de zon', gaat over deelauto's. Er wordt over nagedacht om deel te nemen in een denktank over mobiliteit van de stad. Dit lijkt op city of the commons. Een soort bewonerspanel dat meedenkt over de mobiliteit in de binnenstad van Heerlen." Verbreding is verder mogelijk door de transformatie van steden of nieuwbouw nadrukkelijker te betrekken: "De transformatie van steden of nieuwbouw heeft gevolgen voor zonne-energie. Nu wordt het stadscentrum verkleind: kantoorruimte moet omgezet worden naar woonruimte. Er is een nieuwe periferie ontstaan in de binnenstad. Het is nog niet concreet, maar het is aan het 'zoemen'." Verbreding streeft de Flitscoöperatie ook na in het bestuur: ze willen een jong bestuur, graag bestuursleden onder de 35 jaar! Verder is het streven naar een ledenbetrokkenheid van 350 leden. Dat gaat volgens de initiator wel lukken. Er zijn 2500 huishoudens, dat is dus een redelijk getal. Verbreding krijgt ook vorm door het oprichten van werkgemeenschappen, commons voor a) communicatie en marketing over panelen, b) ledenwerving, c) het bestuurlijke rond de coöperatie. Verder wil de Flitscoöperatie ook komen tot het opzetten van een Voedselraad. Verbreding vindt verder plaats via de opbrengsten van zonne-energie: "Adoptie van zonnepanelen leidt tot korting op de energierekening en je krijgt zeggenschap op leefbaarheid in je leefomgeving door winsten in te zetten voor voorzieningen in gebied. Winsten worden ingezet in zichtbare en maatschappelijk gedragen projecten in de stad. Bijvoorbeeld verduurzaming van bestaande panden. Of het plaatsen van kunst, bloembakken en bankjes in de openbare ruimte."

Verdieping wil men krijgen door een combinatie van energie en warmwater: "Technisch: de oude mijngangen onder de grond met water en is 70 graden. Dit kan opgepompt worden. Om dit op te pompen, is stroom nodig. Nu kijken hoe ze dit kunnen combineren met zonne-energie. Het risico zit in de afname van warm water. Wat je opwekt, moet je kwijt, dus je moet afnemers hebben. Het moet renderen. Als je moet salderen, ben je je rendement al kwijt. Gesprekken hierover lopen. Het is nog heel prematuur." Verdere verdieping wordt vanuit de werkgemeenschappen verwacht: "De werkgemeenschappen gaan met allerlei initiatieven aan de slag. Als er straks 2000 tot 3000 euro in de pot zit bij werkgemeenschappen, dan gaat er wel wat gebeuren. Eerst gaan we nu de entiteiten opzetten, de organisatie optuigen de komende maanden." 


\subsection{Aanjaagmechanismes}

De organisatie Lijnspel is door de gemeente aangezocht om een energiecoöperatie op te zetten. Veel kennis van de organisatie en van de PTRN is gebruikt om te komen tot een flitscoöperatie

(Energizing). Het opzetten van de coöperatie is nog niet geheel gerealiseerd: de statuten dienen nog de notaris te passeren. Vooralsnog zijn er al veel tastbare resultaten die het experiment - het proces van oprichten van een energiecoöperatie - opleverde.

De zichtbare resultaten en daarmee vooral de formule van lagere energiekosten, meer zeggenschap over de directe leefomgeving en investeringen in publieke voorzieningen in de leefomgeving maken het aantrekkelijk om lid te worden van de flitscoöperatie (logic of attraction).

De flitscoöperatie is een voorbeeld van een coöperatie die leidt tot toegevoegde waarde voor de gemeenschap en het gebied. Het zou daarmee een voorbeeld kunnen zijn dat meer navolging krijgt. De eerste stap in Heerlen-Centrum is 5000 zonnepanelen. Het moet voor heel Heerlen eigenlijk naar 25.000 panelen gaan. Als het model draait in centrum Heerlen kan het ook draaien voor andere wijken in Heerlen (olievlekwerking). Lijnspel/Toog-dialoog nam initiatief om huiseigenaren, pandbezitters, ondernemers en bewoners in het centrum bij elkaar te brengen en enthousiast te maken voor zonnedaken. Ook is een beslisstructuur geïntroduceerd voor een vorm van coöperatie en verdeling van winst uit energie (verbinden). De flitscoöperatie wordt net opgericht. Het is daarmee nog de vraag of het in praktijk robuust is, al is die verwachting er wel. Het opgezette model achter de flitscoöperatie geeft veel mensen vertrouwen. 


\section{Reflexieve monitoring coalitie Groen verbindt in Alblasserwaard- Vijfheerenlanden}

\subsection{Introductie}

In de regio Alblasserwaard-Vijfheerenlanden is het regionale netwerk 'Groen Verbindt' actief. Dit netwerk bestaat uit ongeveer 25 projectleiders van projecten die een subsidie ontvangen van de Provincie Zuid-Holland en die samen het Meerjaren Programma (MJP), met een looptijd van 2016 tot 2020, uitvoeren. Binnen het netwerk is een gebiedscoalitie actief, bestaande uit vertegenwoordigers van gebiedsprojecten, onderwijs, gemeenten, provincie, burgerinitiatieven en projectleiders (Sol, 2020). De coalitie is de spin in het web van het netwerk Groen Verbindt.

De coalitie Groen Verbindt Alblasserwaard-Vijfheerenlanden streeft sinds 2016 naar duurzame gebiedsontwikkeling: duurzame voedselproductie gecombineerd met water, recreatieontwikkeling, landschapsbeheer en biodiversiteit. De gebiedscoalitie wil de streek groener, levendiger, toegankelijker en duurzamer te maken, ook na het Meerjarenprogramma (Sol, 2020). De coalitie heeft de behoefte om een meerdaagse training 'Reflexieve Monitoring in Transities' te volgen. De drie expliciete doelen zijn gezamenlijke taal ontwikkelen, inspirerend leren met elkaar en teambuilding. De focus ligt op gezamenlijkheid en verbinding richting actie via reflexieve monitoring (Sol, 2020). Twee trainers verzorgden de training.

\subsection{Herkennen en identificeren van small wins}

De kleine stap bestaat uit een training (vier cursusmiddagen) reflexief leren die twee trainers verzorgen voor de coalitie Groen Verbindt. Het tastbare resultaat is dat, doordat de coalitie met de training reflexieve monitoring aan de gang is gegaan, de coalitie heeft geleerd om te heroriënteren, flexibel te zijn en nieuwe energie te ontwikkelen (Sol, 2020). Een tastbaar resultaat is leren, spiegelen en reflecteren op uitvoeringsprogramma's: kritisch reflecteren op jezelf en vervolgens proberen toe te passen bij het uitvoeringsgerichte. In de kern heeft de training bijgedragen aan een sterker rolbewustzijn van de coalitie: wat zij te doen heeft in het gebied. Ondersteunend daaraan is hoe de samenwerking intern binnen de coalitie verloopt. Er is een groter besef van de onderlinge rolposities en hoe die elkaar nodig hebben en aanvullen en welk gedrag daarvoor nodig is. De coalitie durfde verder meer andere partijen uit te nodigen om het mede te laten trekken. Ze richten zich dus meer op de wereld buiten de coalitie.

De diepgaande verandering is om een reflexieve cultuur en taal te ontwikkelen, maar een cultuur verandert niet met een training van vier middagen. Een reflexieve cultuur dient bij te dragen aan een duurzame gebiedsontwikkeling van Alblasserwaard-Vijfheerenlanden. De (deels) overwonnen barrières zijn als volgt toe te lichten.

Financiën. Financiën zijn een barrière voor de leden van de coalitie Groen Verbindt die niet voor een organisatie betaald werk verrichten. Vrijwilligers willen best tijd en energie investeren, maar er zitten grenzen aan. Als anderen worden betaald, is het moeilijk om wederkerigheid te organiseren.

Regelgeving. Een van de trainers geeft aan dat leden van de coalitie Groen Verbindt te zien zijn als change agents: "Al die change agents, of ze nu in netwerken zaten of in praktijken, ze hebben allemaal last van een soort erosieproces. Het is gewoon slopend wat er gebeurt: het moeten opboksen tegen een institutionele omgeving die veel groter is dan jij en jou iedere keer uitlegt dat je moet voldoen aan systeemregels, vanwege bijvoorbeeld rechtmatigheid. Of iets is niet voorzien vanwege subsidiecategorieën. De middelen lijken de doelen geworden." Een andere barrière wordt door een van 
de trainers gevoeld vanuit de politiek en de hierachter liggende regels: "Een ander aspect is dat de dynamiek van het openbaar bestuur niet is ingericht voor het laten ontluiken van slow processes. Politiek is vooral gericht op het uitvergroten van verschillen. De dynamiek in onze processen is gericht op verbinding en eenheidsvorming." Een van de trainers geeft aan dat de koppeling moeilijk blijft: "Hoe kan je het adaptieve vermogen voor maatschappelijke behoeften en dynamiek dat tot uitdrukking komt in leervermogen koppelen aan de lineaire politiek? Het ene is ontstaan en fluïde en het andere zijn meer cycli van besluit- en planvorming. Mensen die daarin acteren, hebben een voorkeur voor het een of ander. Dat merk je ook in teams: wat gaan we nu doen? Een doe-gerichte oriëntatie, en er zijn mensen die meer stil willen staan bij wat er gebeurt."

Overtuigingen. De overtuigingen van de trainers richten zich vooral op de diepere waarden van de coalitieleden: "Door mentaal eigenaarschap worden resultaten geboekt." En: "Omslag in anders denken gaat langzaam." "Door mensen te verbinden worden ook inhoudelijke thema's verbonden." Volgens de trainers gaat het om een combinatie van een inhoudelijke actielijn, handelingsperspectief en daarop spiegelen, leren en samen iets indienen: "Regionale gebiedsontwikkeling is ontdekken hoe je elkaar aanvult. Competenties bij elkaar herkennen en elkaar hiermee verrijken: het kunnen of kennen. Denkers/filosofen versus doeners/uitvoerders. Als je ziet dat het allebei van waarde is en je hier ruimte voor maakt, dan is dat nieuw."

Kennis en relaties. Omtrent kennis geeft een van de twee trainers het volgende aan: "Vragen naar successen en de eigen persoonlijke bijdragen maakt mensen bewuster van hun eigen persoonlijke krachten en die van de groep. Het bleek dat ze elkaar ook vaak hier niet over vertelden en ook niet naar de buitenwereld toe. De kennis was dus niet expliciet gemaakt." Volgens een van de twee trainers is met de trainingen in een minivorm gewerkt met reflexieve monitoring, waar is nagegaan waar naast successen ook iets nagelaten: "Dat levert eerlijke eyeopeners op, waarmee de groep op een wat dieper niveau komt: waar overtuigingen, gevoelens en waarden zitten. Ga je dan nog verder dan wordt het nog wat heftiger: chaos, onzekerheid, misverstanden en een onprettig gevoel." De inschatting van een van de trainers was dat de coalitie dit aan kon gezien de vitaliteit aan het begin: "Hoe zit ik er zelf in? Wat verwacht ik van de ander? Kloppen de rollen dan wel? Het gaf vitale spanningen naar elkaar, wat normaal is. In begeleiding dien je het niet persoonlijk te maken en het als een proces te zien zonder oordelen. Er werd nog een extra bijeenkomst ingelast voor het niet weten: welke extra perspectieven kwamen er omhoog? Dat leverde een aantal inhoudelijke lijnen en meer het benoemen wat personen van elkaar nodig hebben."

Een van de trainers geeft aan dat bij relaties niet vaststaat wat voor kennis tot stand komt: "Bij ontmoetingen, in coalities of via de PTRN, weet je niet precies wat eruit komt. Naast inhoudelijke doelen gaat het om heel andere resultaten. Je vraagt bijvoorbeeld: wat wil jij nu als mens het liefste? Vanuit je hart? Niemand die ooit die vraag stelt. Als een wethouder heeft benoemd voor zichzelf wat het is, dan is het ook gemanifesteerd." En: "Integraal ontwerpen zijn we niet zo gewend. Het zijn kleine stappen. Het is gevoelig voor context en individuele oriëntaties. Van tevoren weet je niet welke uitwisselingspatronen er komen en waarover mensen het met elkaar gaan hebben. Of men klaar is voor systeemdenken of voor integraal denken, dat kan wel eens verschillend zijn. Omdat dit zo is, blijft het gevoelig en maatwerk."

Een ander punt dat een trainer aandraagt, is de ongelijksoortigheid in informatiegehalte en hoe hiermee is om te gaan: "Dat gaat ook over leiderschap: dat wat je weet en denkt ook beschikbaar stellen aan het collectief. Hoe doe je dat? Hoe zit je daar in? Alblasserwaard-Vijfheerenlanden gunden dat elkaar. Natuurlijke opinievormers en besluitvormers op de juiste plekken. Er zijn ook plekken waar dit niet lukt."

Over de PTRN zijn de trainers enthousiast. De PTRN wordt door de trainers gezien als een netwerk van gelijkgestemden: "Allemaal pioniers die eigen stukjes terrein verkennen. De PTRN ziet dat het combineren van kennis zo belangrijk is. Dat is de volgende stap waar de PTRN aan toe begint te komen. Iedereen heeft nu geëxperimenteerd op zijn terrein. En dat werkte. Niet dat alles een succes is geworden, maar er is wel een effect: leren is ook wat je beter niet kunt doen." Met de PTRN bestaat er een netwerk voor ervaringsuitwisseling: "Het zijn allemaal procesadviseurs of zzp'ers. Als zzp'er heb je opdrachten nodig. Dat stelt je in staat om het verder te brengen en het is leuk, want van 
waarde. Daar heeft het netwerk een rol: financieel en voor kennis- en ervaringsuitwisseling." Dit laatste is als volgt toe te lichten: "Ervaringen en kennis uitwisselen aan de voorkant om dat complexe regionale werk te doen, dat is ook voor een deel opboksen tegen een systeemwereld. Hoe doe je dat? Wat kom je dan tegen? Daar kan je elkaar bij de PTRN bij helpen en elkaar in steunen. De mensen zijn door de tijd heen met elkaar vergroeid geraakt om te benoemen wat zich dan voordoet." Volgens de trainers is de PTRN het waard dat ze wordt gefaciliteerd in het samen benoemen van kennis en inzichten en dat het veilig boven water wordt gehaald. Daar moeten ze in de toekomst over nadenken, ook als de PTRN groeit. Doe daar voorzichtig mee.

Geconcludeerd kan worden over de (deels) overwonnen barrières dat de ongeschreven beleidsregels en politieke regels een reflexieve cultuur bemoeilijken. De overtuiging van de trainers is dat reflexieve monitoring nodig is om te leren en te verbinden en dit gebiedsprocessen uiteindelijk ten goede komt. Het leidt tot nieuwe kennis over achterliggende waarden, motivaties en overtuigingen. De PTRN wordt gewaardeerd vanwege de kennis- en ervaringsuitwisseling.

De verbinding tussen de inhoudelijke en sociale verandering is als volgt. De sociale verandering betreft de leergang die de coalitieleden ondergaan. De trainers benadrukken dat sociale innovatie niet zacht is en niet moet worden weggemoffeld. Social engineering verdient veel meer aandacht.

De inhoudelijke verandering is streven naar regionale duurzaamheid via een integrale aanpak en regionaal commitment. De inhoudelijke verandering komt tot uitdrukking in het regionaal programma voor Alblasserwaard-Vijfheerenlanden, waarbij de vier reflectiemiddagen voedend zijn geweest.

In de regio Alblasserwaard-Vijfheerenlanden blijft men open staan voor vernieuwing en verder leren en experimenteren. Met het blijven organiseren van bijeenkomsten om netwerkend te leren, ontstaan nieuwe samenwerkingsverbanden, nieuwe thema's en nieuwe projecten.

\subsection{Verspreiden, verbreden en verdiepen}

Verspreiding vond plaats via de Leermodule 'change agents voor regionale netwerken' bij de provincie Zuid-Holland. Ook in Limburg is geprobeerd een regionaal transitielab en gebiedsbenadering op te zetten, maar dit is niet helemaal gelukt. In Limburg was een beginnetje gemaakt met een transitielab duurzame ontwikkeling, maar dat is uiteindelijk gestrand: "Je kunt niet alleen vrije tijd erin stoppen. Op een gegeven moment hebben we gezegd: we wachten op een nieuw plan. Op een gegeven moment word je ingehaald door allerlei andere dingen." In Friesland is wel met succes begonnen aan een transformatielab. Een van de trainers is begonnen aan een transitielab in Friesland: "Voor mij is dat het prototype. Ik denk dat dit zo uitgerold zou kunnen worden naar andere regio's. Je kunt er veilig falen. Er ontstaat heel veel creativiteit." Omtrent verspreiden en versnellen, maakt een van de trainers een kanttekening: "Het zijn slow processes die wij doen. Een combinatie van een inhoudelijk actieperspectief en versnellen versus maatschappelijk leren." Dat je transities kunt versnellen en herhalen, wordt door de trainers niet in meegegaan: "Het blijft maatwerk. Het is zo afhankelijk van veel factoren. Je wilt kantelende economische praktijken. Het is circulair en streekgebonden bedoeld. Dat verder brengen zijn meerjarige cycli. Dat gaat heel langzaam. Langzaam verspreiden kan dus wel, maar het zal er altijd weer anders uitzien." Omtrent de pogingen tot verspreiding wordt het volgende opgemerkt: "Er is slechts sporadisch geprobeerd om de aanpak in Alblasserwaard-Vijfheerenlanden in meer polders of gebiedsprocessen toe te passen. Omdat het zo contextgevoelig is, is er geen sprake van een-op-een kopiëren. Zuid-Holland heeft wel een afdeling voor toolontwikkeling voor sociale innovatieprocessen. Die hebben een vitaliteitsmeter ontwikkeld voor sociale innovatieprocessen."

Verbreding ontstaat volgens een van de betrokkenen door reflexiviteit: "Reflexiviteit leidt tot lerende cultuur. Wat voor kennis en gedrag ontstaat er dan? Wat gaat anders lopen?" De reflexieve monitoring is ook toepasbaar in opdrachten voor onderwijs (scholen), gezondheid, politieke partijen.

Reflexieve monitoring zet ook aan tot verdieping: "Reflexieve monitoring leert ons dat we niet alleen uitvoeringskonijnen zijn. Het gaat vooral om het beschikken over mentale ruimte en het inzicht dat 
leren leidt tot ander resultaat." De verdiepende volgende stappen in Alblasserwaard-Vijfheerenlanden zouden volgens een van de trainers pendelbewegingen zijn geweest tussen uitvoeringspraktijk en beheren. Bij samenvoegen van gemeenten verandert de groepssamenstelling. Aan de orde was geweest om dat te volgen en te begeleiden.

Een van de trainers zit in een Europees (Erasmus-plus) project, gericht op het opleiden en accrediteren van transitiekundigen (Luxemburg/ Ecolyse). Tijdens die opleiding komt ze zelf met vragen tot verdieping: hoe kan je de reflexiviteit in governancenetwerken versterken? Wat is daar voor nodig? Wat gebeurt er in een netwerk? Hoe gaan provincies en gemeenten om met een andere rol in de Omgevingswet? Welke zaken gaan anders door een reflexieve cultuur? Met die vraag loopt de trainer al jaren rond en zij weet niet waar zij die kan beleggen en zij zou graag aantonen wat er anders gaat door een reflexieve cultuur. Het zijn ontwikkeltrajecten.

De ervaring binnen deze casus is dat reflectie op verspreiden, verbreden en verdiepen moeilijk gaat: "Dit zijn trage, meerjarige processen. Ze hebben soms maanden nodig om te weten wat reflexief, transitiegericht werken betekent. De waan van de dag is: je hebt er geen tijd voor. Je kunt in vier middagen niet de transitiecultuur beleggen voor een groep. Dat heeft meer begeleiding en langere monitoring nodig. We waren nog aan het begin met die vier middagen. Sommige mensen willen impact zien of persoonlijke verandering of willen het weer opnieuw oppakken. We zaten toen net voor de zomer en het programma begon te dringen. De mensen waren overladen en konden nauwelijks nog laten bezinken wat ze nu gedaan hadden. Dat had tijd nodig. Ik had nog een reflectie over de e-mail aangeboden. Bij de provincie is er meer gereflecteerd, die hebben er ook meer tijd ingestopt. Als je er meer tijd instopt, dan haal je er ook meer uit. Mensen zijn niet bereid om er aan de voorkant al veel tijd voor te reserveren. Er moet een afstemming zijn tussen de doelen die ze willen bereiken en wat ze erin willen stoppen."

\subsection{Aanjaagmechanismes}

De gebiedscoalitie Groen Verbindt is vol energie, maar gunde zichzelf niet de rust en het plezier om blijvend te investeren in reflexieve monitoring (energizing). De gebiedscoalitie experimenteert nog steeds op andere manieren, bijvoorbeeld bij het maken van een gebiedsvisie voor Molenlanden. Het feit dat een voltallige coalitie bereid is om vier middagen te investeren in reflexieve monitoring was op zich al uniek (logic of attraction). De reflexieve monitoring heeft een olievlekwerking gehad richting de provincie Zuid-Holland. Een olievlekwerking naar de andere landschapstafels is uitgebleven (olievlekwerking). De reflexieve monitoring leidde ertoe dat de deelnemers van de gebiedscoalitie meer van zichzelf lieten zien en ook naar de anderen en dat leidde tot verbondenheid en vertrouwen, tot een gezamenlijke gebiedsvisie en een open opstelling richting de buitenwereld: ze gingen andere partijen uitnodigen om mee te werken aan de gezamenlijke gebiedsvisie (verbinden). De reflexieve monitoring is als aanpak robuust, maar het lukt niet om mensen hier blijvend in te laten investeren. 


\section{$9 \quad$ Oprichting Coöperatie Bommelerwaar}

\section{$9.1 \quad$ Introductie}

De Coöperatie Bommelerwaar is een gebiedscoöperatie van en voor bewoners en ondernemers van de Bommelerwaard. Coöperatie Bommelerwaar is op 28 juni 2016 opgericht, onder andere om samen te werken aan een energieneutrale Bommelerwaard. Winst is niet hun doel, maar een middel waarmee ze hun gebied duurzamer en weerbaarder kunnen maken. Het is hun ambitie om de lasten en de lusten van de energietransitie in de Bommelerwaard in evenwicht te brengen en verder in brede zin bij te dragen aan een coöperatieve gebiedseconomie. En ervoor te zorgen dat het geld dat wordt uitgegeven aan energie, zo veel mogelijk in hun eigen gebied blijft. Hiertoe wil Coöperatie Bommelerwaar samenwerken met de gemeente en (lokale) ondernemers. De coöperatie werd heel doelbewust neergezet vanuit het Rijnlandse gedachtegoed van De Coöperatieve Samenleving en volcontinu met inbreng van kennis en netwerken van een van de kwartiermakers die ook daar bestuurder was.

\subsection{Herkennen en identificeren van small wins}

Het verzoek vanuit een medebewoner in een buurtkrant wie er wilde helpen met een klein zonnepanelen initiatief (Van Bekkum, 2019), leidde uiteindelijk tot de (kleine) stap van de oprichting van de Coöperatie Bommelerwaar als model voor de Rijnlandse Gebiedscoöperatie; ontwikkeling van een landelijk uniek echt inclusief, local-for-local coöperatief stroomconcept; de vertaling van het Rijnlands coöperatieve gebiedsmodel naar de grootschalige gebiedspraktijk middels een knap beargumenteerd windenergieproject dat in no-time een volledige ommedraai teweegbracht in de lokale politieke omgeving. Het opzetten van een coöperatie is een enorme stap, maar gerelateerd aan de diepe verandering die wordt nagestreefd, benoemen wij het als een kleine stap. Het blijft uiteindelijk een middel om tot een transitie te komen en daaraan gerelateerd is het als een kleine stap te zien. Tastbare resultaten zijn:

1. Oprichting van de Coöperatie Bommelerwaar, een coöperatie met producten en diensten voor een gezonde gebiedseconomie, met bijna 200 leden. Uiteindelijk waren de producten en diensten vooral gericht op energie.

2. Het opwekken van lokale stroom via twee zonnedaken middels een nationaal uniek stroomconcept waardoor deelnemers ongemerkt vanuit hun energierekening geld inleggen en iedereen dus kan deelnemen, rijk of arm.

3. Realiseren van een gebiedseigen windmolenpark met de support van een voltallige gemeenteraad in een zeer wind-onvriendelijke gemeente na een uitgekiend 'schaakspel'.

De diepgaande verandering is de ontwikkeling van een publiek-burgerlijk-privaat gebiedsgovernance model vanuit participatie, gezamenlijke legitimiteit, zeggenschap en aansprakelijkheid. De Coöperatie Bommelerwaar diende een begin te maken in de praktijk van een inclusief, gebiedseconomisch model gericht op gebiedswaarde ('van, voor en door het gebied' in termen van zowel gebruik als eigendom). Met heel veel persoonlijke inzet, in een weinig ontvankelijke omgeving en met zeer schaarse middelen heeft de Coöperatie Bommelerwaar toch in beperkte tijd laten zien dat dat kan (maar zonder voldoende steun met die intensiteit niet vol te houden blijkt). De (deels) overwonnen barrières zijn als volgt toe te lichten.

Financiën. Voor de Coöperatie Bommelerwaar moest een stroomconcept ontwikkeld worden voor de kosten en baten rond energie. Er was in Rivierenland al een coöperatie die een stroomconcept had ontwikkeld. De initiator: "Vanuit mijn coöperatiekennis vond ik het niet goed, omdat het eigendom en daarmee financiële rendement losgekoppeld was van de stroomafname, waardoor je een intern belangenconflict krijgt tussen leden-beleggers en leden-afnemers. Dat gaat zich wreken in je strategische keuzes: goedkoop veel stroom opwekken of hoog financieel rendement dat betaald wordt 
door je leden. Als ik het goed wil doen, dan heeft het te veel juridische, fiscale kanten. En accountancy om uit te rekenen of het allemaal uit kan." De initiator benadrukt dat het uitmaakt of een coöperatie voor de gemeenschap of voor markteigenaren wordt opgezet: "Er is een concurrerend alternatief bij Zaltbommel. Niemand die hier iets van wil, behalve de boeren zelf als eigenaren. Zij willen het project verlengen en er nog wat molens bijplaatsen bij Maasdriel. Dan gaat het dus om het belang van individuele boeren. Je ziet een enorm publiek-privaat bestel. Wij proberen ons in te vechten om tot een burger-publiek-privaat bestel te komen." De initiator heeft heel veel tijd gestopt in de coöperatie en nam daarmee financieel veel risico. Ze hebben geprobeerd om steeds geld aan te trekken bij de provincie, beide gemeenten, de Rabobank. De initiator: "Ze wilden flyers sponsoren. Als we expertise nodig hadden, wilden ze die ook betalen, maar niet onze uren. Alle expertise die we dus zelf inbrachten, wilde men niet waarderen." De coöperatie heeft ook zelf geprobeerd geld te verdienen: "Toen we nog geen vier maanden bestonden, hebben we appels geplukt en verwerkt tot duizend vijfliterpakken appelsap; het rendement was voor de coöperatie. Maar het liep niet meteen storm onder de leden om volop appelsap te gaan verkopen en heeft uiteindelijk veel inspanning gekost." De PTRN speelde een belangrijke rol voor de financiën van de coöperatie: "Dat ondersteunde ons om ons Bommelerwaar-Stroomconcept te kunnen uitontwikkelen."

Regelgeving. Er zijn statuten opgesteld voor de Coöperatie Bommelerwaar (Ton \& Van den Broeke notarissen, 2016). Deze statuten brengen tot uitdrukking dat de coöperatie echt gericht is op de gemeenschap, het gebied en niet een marktgeoriënteerde onderneming is. De initiator: "Ik heb nog nooit zulke gedetailleerde statuten opgesteld om in allerlei mogelijke situaties te kunnen voorzien. Deze statuten zijn vervolgens model gaan staan voor gebiedscoöperaties elders in het land." De eerste overwonnen barrière is daarmee het opstellen van statuten. Een andere overwonnen barrière heeft betrekking op het verkrijgen van vergunningen voor een windmolenpark. De initiator: "Er waren vergunningen nodig voor het windmolenpark. De twee gemeenten in de Bommelerwaard zijn stimulerend geweest en demotiverend. Stimulerend: de Coöperatie Bommelerwaar heeft een dak gekregen om zonnepanelen op te leggen, al op de dag van de oprichting van de coöperatie.

Demotiverend: al vanaf het moment dat de coöperatie er was, ondervonden we weerstand. Er is nooit een wethouder geweest die specifiek vond dat we met onze gebiedsbenadering met iets interessants bezig waren. Wij moesten hen altijd overtuigen in plaats van dat we samen optrokken. Eerst wil je dat ze het begrijpen en dan nog dat ze het ook willen. Er zijn oude belangen, families die ingenesteld zijn in oude structuren. Er is hier een cultuur van zorgen voor je zelf, je vrienden en partijgenoten." De initiator geeft aan dat de relatie met de gemeente niet allemaal kommer en kwel was: "Er was één partij en raadslid die zei dat hij het wilde hoe de Coöperatie Bommelerwaar het zag. Die is er binnen de raad voor gaan staan. Soms heb je aan één partner aan de andere kant genoeg. In de beweging die er toen ontstond, konden we door slimme programmering en krachtige argumentatie in heel korte tijd, in feite twee maanden, heel veel voor elkaar krijgen en kregen we de raad unaniem achter ons plan." Aangemoedigd vanuit DuurzaamDoor wilde de initiator in augustus 2018 als coöperatie aan een regiodeal schrijven. De wethouder vond dat de gemeente dat moest doen en niet een burgerinitiatief. De systeemweerstand was zeker toen echt heel groot. Ze deden het toch, maar werden niet gehonoreerd. Een jaar later ging een regiodeal naar de Regio Rivierenland.

Overtuigingen. De initiator is er tijdens het proces achter gekomen dat het oprichten van een coöperatie vanuit een bepaalde visie niet betekent dat mensen deze dan meteen omarmen: "Het uitvoeren en implementeren is geen probleem. Het gaat om een groep met de goede nieuwe houding. Wat is dat dan? Materialisme, consumentisme en individualisme is in het belang van een klein, rijk percentage van de wereld. In ecologie is alles wel verbonden. Als één het moeilijk heeft, heeft dat gevolgen voor het geheel. Het gaat dan over betrouwbaarheid, rechtvaardigheid. Bij Bommelerwaar zij we eigenlijk toch eerst vanuit een visie gaan implementeren; het leren hadden we niet gestructureerd en zou dan eigenlijk later alsnog moeten gebeuren. Ik probeer dat nu om te draaien." Ook het ontbreken van urgentie speelde de Coöperatie Bommelerwaar niet in de kaart: "We wilden de mindset veranderen. Maar er is in deze regio niet een cultuur om je in te laten met wereldproblemen. De meeste mensen hebben het economisch goed voor elkaar, waarmee er een urgentie ontbreekt." Een andere overtuiging van de initiator: "Coöperatie Bommelerwaar vraagt om een houdingsverandering. Veel mensen denken aan een halverwege verandering en zitten deels toch nog met hun houding vast in het oude systeem. Naarmate het aantal leden groeit en activiteiten gestroomlijnd moeten worden, vallen mensen vaak terug in oude reflexen." De initiator heeft vooral de overtuiging dat marktpartijen 
voor eigen belang gaan en coöperaties voor gebieden en gemeenschappen: "Ketens onttrekken waarden aan gebieden. Ga als persoon een goede houding aannemen: samenwerken, verbondenheid, niet vanuit het eigenbelang, niet zo gericht op financieel gewin. Ga een groep om je heen krijgen met dezelfde waarden en biedt dan de coöperatie als organisatievorm aan. Dat laatste is dan implementatie. Ik heb veel geleerd van de Bommelerwaar ervaring."

De initiator heeft de overtuiging dat de tijd van Corona aangegrepen zou moeten worden om van de sterk ingerichte marktnaties meer gemeenschapsnaties te maken: "Corona heeft de kwetsbaarheid getoond van het mondiaal ingerichte publiek-private systeem - waar markt alles dominerend is - en lean ingerichte ketens, waar zo veel mogelijk kosten worden weggesneden en dus nergens meer een buffer is. Alles ten koste van bodem, water en lucht. Ten koste van hele volken en de winsten voor een zeer klein aandeel van de wereldbevolking. Het gaat ook om veerkracht, overleefbaarheid. Dat is dus eigenlijk de strijd met sociale en natuurwetten." En verder: "We zouden de coronacrisis dienen te benutten voor een systeemwisseling. Hoe kunnen we deze crisis gebruiken voor een systeemomslag? Hoe is het leven nu georganiseerd? Hoe willen we het eigenlijk - en welke houding en veilige omgeving is nodig om daar te komen?" De initiator organiseert hier digitale overeenkomsten over.

Kennis en relaties. Een relatie dat de Coöperatie Bommelerwaar stimuleerde was de inzet van de energiecommissaris. De initiator: "Ons eerste zonnedak werd geopend op de middag van ons tweejaarfeest op 27 juni 2018. 's Avonds was Nationaal Energiecommissaris Ruud Koornstra onze gastspreker. Hij was dusdanig enthousiast geworden dat hij ons als kwartiermakers spontaan benoemde tot Regionaal Energiecommissaris van de Bommelerwaard." (Van Bekkum, 2018). Dit had vervolgens weer een positieve uitstraling op de gemeenteraad.

De initiator heeft kennis en relaties binnen de Coöperatieve Samenleving en binnen de PTRN benut. De initiator: "Vanuit De Coöperatieve Samenleving had ik binnen de PTRN meegewerkt aan een leerprogramma: het gebied is de klas. Het Leerprogramma begon binnen onze lokale coöperatie weerstand op te roepen. Je hoopt mensen mee te nemen in een proces en vanuit een gezamenlijke lerende houding. Dat lukt niet altijd."

De kennisrelatie met andere programma's wordt als volgt geschetst: "Om iets lokaal neer te zetten, helpt het als je kan laten zien dat er vanuit programma's aandacht voor is: PTRN, Democratic Challenge, Overlegorgaan Infrastructuur en Milieu [tegenwoordig Overlegorgaan Fysieke Leefomgeving] en diverse andere programma's. We doen het niet alleen. Er zijn heel veel partijen bezig om een omslag voor elkaar te krijgen. En bovendien: je ontwikkelt het echt niet voor je eigen gebiedje, maar omdat je deel uitmaakt van groter proces: dan heeft het zin." Naast het financiële deel was de PTRN ook een steun van gelijkgestemden. De initiator: "Wij gingen ook naar de PTRN om zichtbaar te maken wat wij op regionale schaal deden, in de verwachting dat het daarmee ook nationaal bekend werd. Ook met het idee dat er vanuit deze programma's een strategie vanuit de rijksoverheid achter zou zitten. Dat is wat tegengevallen: Het luisterende oor vanuit Den Haag lijkt nog vooral gericht op de private partijen, in plaats van de burgersamenleving." Tijdens een bijeenkomst van de Participatietafel Voedsel werd geopperd om topsectoren open te breken door bijvoorbeeld 5 tot $10 \%$ van het budget vrij te maken voor burgerinitiatieven, coöperaties in plaats van bedrijven.

Geconcludeerd kan worden over de (deels) overwonnen barrières dat financiën een barrière waren. Allereerst moest een stroomconcept, een verdienmodel voor de coöperatie worden ontwikkeld. Daarbij diende een keuze te worden gemaakt of de op te zetten coöperatie marktgericht of gemeenschapsgericht zou worden en werd concurrentie ondervonden van een markgerichte coöperatie. Financiën zijn bevorderd door de PTRN. De initiator heeft ook persoonlijk veel kosten gemaakt en daarmee risico's genomen om het initiatief te realiseren.

Regelgeving werkte zowel bevorderend als belemmerend. Er dienden statuten te worden opgesteld die de identiteitsvorming van de coöperatie bevorderde. Regelgeving voor vergunningen vormde een barrière. Kennis en relaties waren belangrijk: steun van één raadslid was genoeg om de discussies over vergunningen te helpen doorbreken. Ook de inzet van de energiecommissaris bevorderde dit. Goede relaties binnen instituties zijn dus belangrijk om het initiatief te bevorderen. Ook de PTRN bevorderde het initiatief vanuit meedenken van gelijkgestemden. Financieel blijft het moeilijk om op 
traditieprogramma's van overheden een beroep te doen, omdat deze alle nog vooral zijn gericht op topsectoren en daarmee op de gouden driehoek van overheden, bedrijven en kennisinstellingen. Deze belemmering zou weggenomen kunnen worden door binnen programma's ook een gering percentage te begroten voor ondernemende burgers en gemeenschappen. De overtuiging van de initiatiefnemer zijn gericht op de gemeenschap en duurzaamheid en zet zich af tegen de instituties die alleen markgericht opereren.

De verbinding tussen de inhoudelijke en sociale verandering is als volgt. Energie was als starter (motor) bedoeld om het proces met publiek, particulier (burgers) en privaat aan te jagen. Vanuit energie wilde de coöperatie het breder trekken naar andere thema's, zoals mobiliteit, voedsel, zorg, wonen etc. Dat is nog niet gelukt. Niet dat men niet wilde verbreden of leren. Het is heel veel werk en kwamen daarmee aan een gestructureerd leerproces onvoldoende toe. Dit is volgens de initiator een leerpunt an sich: niet alles tegelijk willen. Als meer mensen de schouders eronder zetten, kan eerder worden versneld, maar om dat voor elkaar te krijgen, is een aanvullende tak van sport, die veel inzet vraagt. De Coöperatie Bommelerwaar is nu vooral een energiecoöperatie die na stormachtige beginjaren nu eerst wil consolideren. Aan het windproject en twee nieuwe zonnedaken heeft men de handen al knap vol.

\subsection{Verspreiden, verbreden en verdiepen}

De verspreiding van het energie-initiatief kreeg op verschillende manieren vorm: het concept Bommelerwaar-Stroom binnenkort voor duizenden lokale huishoudens via het windproject, via het lidmaatschap van De Coöperatieve Samenleving (DCS), via o.a. Coöperatie Lingewaar en diverse andere gebiedsgerichte coöperaties aangesloten bij DCS en via HierOpgewekt en andere landelijke netwerken. De verbreding van het energie-initiatief is nog niet goed gelukt. Er waren voornemens richting mobiliteit, zorg, wonen en voedsel (dat komt ook terug in het logo van de Coöperatie Bommelerwaar). De strategische focus is eerst iedereen met een energierekening meenemen. Omtrent verdiepen is het voornemen om meer te investeren in professionalisering, gelijke houding en waarden en gemeenschapsontwikkeling.

\subsection{Aanjaagmechanismes}

De energie kwam voor een groot deel van enkele personen. Die personen staken heel veel tijd in de Coöperatie. Soms wel 30 tot 80 uur per week. Enerzijds is het verbazingwekkend hoever enkele personen kunnen komen, anderzijds is er de vraag: hoe lang is dit vol te houden? Financieel wordt risico gelopen en alle tijd die naar de coöperatie gaat, gaat ook ten koste van iets anders. De PTRN was daarbij vaak weer de zet om door te gaan: zowel financieel als de aansporingen van de gelijkgestemden (energizing). Voor de initiator heeft het project prachtige inzichten opgeleverd (experimenteren). Hij heeft ervaren dat statuten niet achteraf tot leven komen, maar dat je eerst 'waardegenoten' dient te vinden en dan pas tot implementatie kunt overgaan. Lukt dat onvoldoende, dan loop je als sprinter een eenzame race.

De statuten van de Coöperatie worden door de oprichter zelf ironisch een 'brain-dump' genoemd (Van Bekkum, 2019). De statuten geven heel scherp de waardeverschillen aan tussen een coöperatie gericht op een gemeenschap en een gebied en een bedrijf of een coöperatie gericht op de markt (logic of attraction).

De statuten van de Bommelerwaar zijn integraal overgenomen door de gebiedscoöperatie Lingewaar en hebben daarna diverse andere gebiedsgerichte coöperaties geïnspireerd (olievlekwerking).

Het verbinden is niet uitgepakt zoals werd beoogd. Er bleef in de visie (omarming van het Rijnlands Gebiedsmodel van De Coöperatieve Samenleving) en consequente implementatie daarvan, afstand tussen de oprichters/kwartiermakers en nieuwe bestuurlijk actieve leden van de coöperatie die moeilijk te overbruggen bleek. Vooral ook door toenemende spanning op de financiële volhoudbaarheid is een van de kwartiermakers uiteindelijk uitgestapt, maar de coöperatie bestaat nog en werkt verder. De coöperatie is robuust, evenals het bijbehorende zonnepark en windpark. 


\section{Oefenrechtbank Notter Zuna}

\subsection{Introductie}

Gemeenten en bedrijven en burgers kunnen zich nog niet goed voorstellen hoe de Omgevingswet in de praktijk zal gaan werken. Wel is te voorzien dat alle ruimtelijke ontwikkelingen die we vandaag de dag starten, gaan vallen onder de regels van deze nieuwe wet. Om tijdig een beeld te krijgen van de werking van deze Omgevingswetregels en met name gevoel te krijgen bij het hoe van de toepassing van deze regels in de praktijk, besloot het College van de gemeente Wierden in samenwerking met de burgers van het gehucht Notter Zuna de antwoorden op die vraag op te zoeken door in de praktijk te gaan oefenen, alsof de Omgevingswet al van kracht was. In het buurtschap Notter Zuna in de gemeente Wierden is een gebiedscoöperatie opgericht: de Coöperatie Notter Zuna. In een manifest hebben zij de gebiedsopgaven benoemd die dwars over allerlei beleidsterreinen heen gaan: wonen, zorg, landschap, energie etc. De gebiedscoöperatie zocht met de gebiedsvisie rechtsbescherming en de gemeente naar haar nieuwe rol. In dit oefentraject werd De Coöperatieve Samenleving gevraagd om procesondersteuning te verlenen, waarover De Coöperatieve Samenleving in het Rapport voor de PTRN inzake de Rijnlandse Gebied Arrangement (2018) heeft gerapporteerd, met name over de oefenrechtbank Notter Zuna in november 2017. De oefenrechtbank is een coproductie van De Coöperatieve Samenleving, met onder meer Universiteit van Amsterdam en Erasmus universiteit, AT Osborne, Adriaanse en Van der Weel advocaten, de gemeente Wierden en de gebiedscoöperatie Notter Zuna. De Coöperatieve Samenleving is aldus in Notter Zuna terechtgekomen na een uitnodiging van de gemeente Wierden in hun streven om burgerparticipatie bij stedenbouw en planologische planontwikkeling meer handen en voeten te geven. Daarbij was er één kern die opviel: Notter Zuna. Er wonen zo'n 1100 tot 1200 inwoners, waarvan 300 boeren. Die hadden een Culturhus en een dorpsvereniging. Tussen 2015 en 2017 is er onder begeleiding van de Coöperatieve Samenleving geoefend met de Omgevingswet door gemeenteraad, college van B\&W en ambtenaren. Wat is er nodig voor burgers om mee te kunnen organiseren vanuit de Omgevingswet? Wat vinden zij dat er in de toekomst nodig is in Notter Zuna? Voor de gemeente leverde dit gevoel op hoe de Omgevingswet kon werken.

\subsection{Herkennen en identificeren van small wins}

De Coöperatieve Samenleving en AT Osborne hebben als kleine stap een gebiedsvisie van de Coöperatie Notter-Zuna (CONZ) voor een fictieve rechtbank laten verdedigen om te bepalen wanneer het proces om te komen tot een gebiedsvisie goed genoeg is. Tastbare resultaten die dit initiatief opleverden zijn:

- Een operationele oefening met de Omgevingswet, met nu al tastbare indicatoren wanneer het voor de bestuursrechter goed genoeg is.

- Overeenstemming in de buurtschap is geen garantie dat het proces tot de Omgevingsvisie stand houdt bij de bestuursrechter.

- Heldere minimumcriteria van de bestuursrechter over functietoedeling, integraliteit, participatieproces en zorgvuldige belangenafweging en compensatie in het proces.

De diepgaande verandering waar het initiatief zich op richt, zijn:

- Bewustwording bij alle partijen van overheid, burgers, boeren, mkb, zzp en de grotere bedrijven van de systeemomslag die er met de invoering van de Omgevingswet aan komt.

- Inzetten op inclusiviteit in plaats van uitsluiting.

- Besef van urgentie bij bestuurlijke vernieuwing, vertrouwen, durven loslaten.

- Ervaren dat weerbarstige vraagstukken leiden naar werkbare oplossingen door cocreatie. 
De (deels) overwonnen barrières zijn als volgt toe te lichten:

Financiën. De gemeente Wierden heeft het betrekken van de Coöperatieve Samenleving mogelijk gemaakt. De oefenrechtbank is door De Coöperatieve Samenleving en haar partners op eigen kosten georganiseerd.

Regelgeving. Het idee was om Notter Zuna voor tet bereiden op de omgevingswet. De initiator: "Daarmee kun je niet wachten tot de dag dat de wet van kracht wordt, dan ben je namelijk vanuit oogpunt van zorgvuldig bestuur te laat. Je doet ook niet onvoorbereid examen. Het gebied is daarbij de klas. Samen leren over een nieuwe wet die inclusiviteit vooropstelt. Die zeggen: we zullen het samen moeten dragen zonder uitsluiting of afwenteling (niet één partij de lusten en de ander de lasten). Het gaat om het achterhalen van de criteria wanneer je dat goed genoeg doet. Die bestuursrechtcriteria werden vooral duidelijk tijdens de oefenrechtbank. Als voorbereiding op de Omgevingswet was dit een goede en vooral leerzame oefening." Het ging om het begrijpen hoe de Omgevingswet in elkaar zit, wat de hoekstenen zijn en hoe de wet geïnterpreteerd kan worden, bijvoorbeeld door de Raad van State. Daarom is er uiteindelijk een oefenrechtbank gehouden, waar gespeeld werd dat ze het niet met elkaar eens waren, in de opstelling van een Raad van Stateprocedure, onder leiding van oud-Raad van State bestuursrechter Van Konijnenbelt en twee advocatenbureaus en twee universiteiten (UvA en Erasmus). Wat was de taak van de Raad ten aanzien van de functietoedeling, wanneer moet die toetsen en wanneer moet die kaders meegeven? Welke minimumcriteria gelden ten aanzien van een zorgvuldig participatieproces en wanneer heb je dat voldoende aangetoond? Kun je de integraliteit van de procesbenadering en de zorgvuldige belangenafweging en de compensatie voor het belang dat moet wijken aantonen? Hierover kwamen heldere uitspraken van de bestuursrechter. De initiator: "Dat is de winst. De bottomline die iedereen wil weten: wanneer is het goed genoeg als het bij de Raad van State komt?" De initiator geeft aan dat het proces ook leerde dat er behoefte was aan organisatiegraad van het collectief: "Iedere burger kan een omgevingsvisie starten, maar die moet er wel voor zorgen dat iedereen kan meedenken." En: "In de Omgevingswet staat dat iedere burger verantwoordelijk is voor de ruimtelijk-economische ontwikkeling van het gebied. Ga je er dan 17 miljoen mensen op loslaten? Of ga je het slim structureren, opdat het draagvlak genereert, impact heeft en vol te houden is? Er moest dus wel iets gebeuren om mensen robuust mee te kunnen laten doen. Het moest in een rechtmatige en doelmatige verhouding tot burgers. Dat is dus niet iedere voordeur apart, maar iets hiervoor organiseren. Wij hebben geadviseerd om een maatschappelijke vereniging in te stellen met een bedrijfsmatige bodem eronder: een coöperatie. Zo kan je afspraken maken als overheid met een gebied, recht doende aan de governance-eisen van doelmatigheid en rechtmatigheid die gelden voor het zorgvuldig openbaar bestuur." Met het proces rond de oefenrechtbank hebben de bewoners de Omgevingswet zelf beleefd. Er waren steeds meer dan 100 deelnemers. Het beklijft volgens de initiator tot op de dag van vandaag. Hij vindt de Omgevingswet een illustratie van horizontale governance: "Alle bestaande wetgeving en governance is verticaal georganiseerd. Het gaat in de Omgevingswet echter verschuiven naar steeds meer horizontale governance. Dan worden problemen zichtbaar van het oude systeem naar het nieuwe systeem."

Overtuigingen. Volgens de initiator is de entiteit ontstaan dat er een coöperatie is waar zowel Culturhus als de dorpsvereniging deel van uitmaakte: "Je gaat dat samen aan, je krijgt inclusiviteit in plaats van uitsluiting. Als je in de statuten opneemt dat het je morele plicht is en bestaansvoorwaarde, dan kun je er ook op sturen." De initiator heeft de overtuiging dat niet zij het proces trokken, maar de bewoners zelf: "Wij mochten deelnemen aan het proces van de burgers. Ze waren zelf gemotiveerd om te werken aan het voortbestaan van Notter Zuna. Wij zijn alleen maar gevraagd om te helpen om het in de context van de Omgevingswet te plotten. Wij waren bij hen te gast en niet andersom." Volgens de initiator maakte het proces van een oefenrechtbank vooral duidelijk dat er tijd nodig is om elkaars culturen te begrijpen: "Een boer heeft een ander cultuur dan een dorpsbewoner. De cultuur van de ander verstaan, is moeilijk. De hele omgang van elkaar begrijpen, waarbij iedereen herkent dat het gebied je gezamenlijk ( $t$ )huis is, maakt dat alles bespreekbaar wordt en dat je niet snel iemand schoffeert." De initiator heeft verder de indruk dat de Omgevingswet aanzet tot een structuurversterking van de economie in de regio. "Je bent dus niet de economie aan het herordenen, maar het gebied. Nieuwe instituties zijn de instituties die dat kunnen 
dragen. Op regioniveau ontbreken die instituties. Dan zou ik ze maar eens gaan maken." En: "Ook voor hele grote multinationals geldt: ze zijn te gast in het gebied."

Middelen. De initiator geeft aan dat het betrekken van bewoners bij de oefening met de omgevingsvisie van de lokale politiek en overheid veel vroeg: "Het proces heeft een zware overstretching-situatie opgeleverd op de burelen van de ambtenaren en het college en de raad. Zo'n exercitie is enorm intensief. Je bent aan het oefenen in de praktijk, terwijl die wet er nog niet is." En: "De mensen in de coöperatie maken een enorm tempo. Dat is vanuit de verticale governancestructuur van de gemeente niet bij te houden. Je oefent vanuit een nieuwe wet, die uitgaat van de horizontale governance, maar je moet je nog verantwoorden vanuit de verticale governancestructuren van de gemeente en de Rekenkamer." De initiator geeft aan dat lokaal vanuit de politiek en overheid goed op de situatie is ingespeeld: "Er werden ambtenaren vrijgemaakt om mee te doen. De wethouder ging haar nek uitsteken. Dit is gebiedsleren; uitvinden hoe de Omgevingswet werkt, afwijkend van de oude wet op de ruimtelijke ordening. Als je mag leren, mag je fouten maken, ook als wethouder."

Kennis en relaties. De initiator heeft voor dit initiatief veel aan de PTRN gehad: "Via de PTRN is een samenwerking gestart met een mededeelnemer die op dezelfde golflengte zit. Zij zijn in dit project samen opgetrokken. Dat is de kracht van de PTRN." De initiator participeert in meerdere participatietafels. "We zitten er in vier. We hebben er eigenlijk een soort programmalijn doorheen aangebracht. We hebben altijd gezocht naar interrelaties tussen de tafels. De PTRN bestaat uit dwarsdenkers die hun eigen verbrandingsmotor aan boord hebben, intrinsiek gemotiveerd en autonoom zijn. Bij de PT Water zijn er veel partijen die toeleveren voor watergerelateerde opleidingen. Bij PT energie zitten mensen uit energiecoöperaties, die ook bezig zijn met de RESSEN. Je hebt ook nog de PT Leren voor morgen. Al die tafels hebben een eigen dynamiek, cultuur en entiteit. Het werkt niet uitwisselbaar hetzelfde. Wel kan er uiteraard inhoudelijk worden uitgewisseld. Als je meer verbinding maakt tussen de tafels, kan de kennis vloeien. Daar moet je dit laatste jaar voor gebruiken. Om er een hele grote klap op te geven en het te organiseren. Het is niet te regisseren, maar je moet kansen creëren dat het kan gebeuren. De ene keer lukt het, de andere keer niet. De tijd moet je vriend zijn. Uiteindelijk lukt het". De initiator geeft aan dat hij niet is gefocust op het voortbestaan van de PTRN als budget-doel: "Het gaat niet om de euro's, het gaat erom dat we willen bewegen. Velen bewegen in de consultancy omdat er euro's zijn. Vanuit dit laatste - de euro's - is de PTRN voor mij een goed middel en geen doel." De doorbraakpotentie zit volgens de initiator bij RVO/DuurzaamDoor: "Het is echter een proces in slow-motion. Het zijn wordingsprocessen. Het is niet: je gooit er een kwartje in en dan komt er meteen wat uit. De ministeries worden plat gelopen door de lobbyisten. Dat noemen wij het poldermodel. Dat is vaak de geplaveide weg naar de tunnelvisie. We kakelen elkaar na, als de belangen maar veilig zijn gesteld. DuurzaamDoor is dwarsdenkende kennis in samenhang, betrouwbaar kijkend naar nieuwe mogelijke werkelijkheden en mogelijke oplossingen, wars van lobby en poldermodel. Schiet DuurzaamDoor en de Participatietafels maar af en ga de tunnelvisie maar in, als dat de keuze van de ministeries is."

Omtrent de (deels) overwonnen barrières kan geconcludeerd worden dat de gemeente Wierden het initiatief heeft bevorderd door er actief aan mee te werken en voor die medewerking geen kosten te berekenen en middelen vrij te maken. De oefenrechtbank is door de initiatiefnemers zelf bekostigd. Qua regelgeving is ingespeeld op een nieuwe wet en is nagegaan wat de wet inhoudt en hoe die mogelijk kan werken door al in te spelen op mogelijke interpretaties in een oefenrechtbank. De overtuiging van de initiator is dat een wet niet alleen een institutionele wijziging inhoudt, maar dat verschillende culturen de werking van een wet nog kunnen belemmeren en hier dus op geanticipeerd dient te worden. De PTRN heeft een belangrijke rol gespeeld bij dit initiatief. Hoewel het geen gefinancierd project uit de PTRN was, is hier wel de connectie tussen twee initiatiefnemers ontstaan die met hun gebundelde kennis het project van de oefenrechtbank mogelijk maakte.

De verbinding tussen de inhoudelijke en sociale verandering ziet de initiator als volgt. De inhoudelijke verandering is de integrale gebiedsvisie volgens de te introduceren Omgevingswet. De sociale verandering is de benodigde cultuurverandering. Het gebied is je (t)huis: dan kan er veel wederzijds en gezamenlijk geleerd worden. De coöperatie Notter Zuna is een plek met energie om verder te leren en experimenteren. Het heeft zeer actieve werkgroepen: landschap, wonen, duurzame voorzieningen, zorg van jong tot out, agrarisch en ondernemen. In andere plekken in 
Nederland zijn gebiedsprocessen gestart waarbij de lessen van de oefenrechtbank uitgangspunt zijn voor het doende lerende gebiedsproces.

Het traject met de oefenrechtbank, die aan te merken is als de small win, heeft veel interesse opgewekt door het hele land en op alle niveaus in samenleving, overheid, markt en kenniswereld.

\subsection{Verspreiden, verbreden en verdiepen}

Het opschalen of verspreiden vanuit de organisatie De Coöperatieve Samenleving is geen doel op zich. Het moet wat de initiator betreft uit de burgers zelf komen of ze hen willen betrekken en een dergelijke exercitie willen doorlopen. Het opstarten van gebiedsprocessen met de kennis van de oefenrechtbank is doorlopend gaande, het werkelijk nogmaals optuigen van een oefenrechtbank, dat is tot heden niet meer gebeurd. Wel is de Coöperatieve Samenleving een halfjaar later gevraagd door het Nederlands Gesprek Centrum om in Haarlem de hele oefening nog eens toe te lichten in bijzijn van Binnenlands Bestuur, het ministerie van BZK en de opleidingsorganisatie van de rechterlijke macht etc. Een Eerste Kamerlid liet zich hierna ontvallen: "Nu weet ik pas waar de wet voor bedoeld is en waarvoor ik eigenlijk heb gestemd." Verdere verspreiding van de uitkomsten van de oefenrechtbank vond plaats via de Coöperatieve samenleving en via de website 'Aan de slag met de Omgevingswet'.

Verbreding werd beoogd door meer gebiedsontwikkelprocessen te starten en dan botsproeven te doen en oefenrechtbanken te organiseren rond nieuw in te voeren wetten of rond gebiedsvisies. De oefenrechtbank is in publicaties terechtgekomen en in een aantal DuurzaamDoor-rapportages, waaronder het rapport Het Rijnlands Gebied Arrangement, waar verdere verdieping plaatsvond en de uitgangspunten van de uitspraak van de oefenrechtbank wordt actief toegepast in lerende gebiedsprocessen waarin De Coöperatieve Samenleving actief is.

\subsection{Aanjaagmechanismes}

Een gemeente Wierden die wil experimenteren, de Coöperatieve Samenleving die zich al theoretisch had verdiept in de gevolgen van de Omgevingswet voor burgers, overheid en bedrijfsleven en een PTRN die ook nog een goede sparringpartner oplevert, maken dat het oefenrechtbankexperiment vol energie werd aangegaan. Veel nieuwsgierige burgers van goede wil maken dat de stemming goed is (energizing). "Het project was één groot experiment. Een dergelijke oefening was nog nooit gedaan." Er is een vonnis gemaakt van de oefenrechtbank. Dit vonnis is aantrekkelijk voor verdere inspiratie en discussie (zie bijlage 2 in Ravenhorst et al., 2018) (logic of attraction). Wat betreft de olievlekwerking: "De praktijkomgeving moet zeggen dat ze dit nodig hebben. Als het goed is, schaalt het project vanzelf." Het opschalen/verspreiden vanuit De Coöperatieve Samenleving is geen doel op zich. Het moet wat hen betreft uit de burgers zelf komen of ze hen willen betrekken en een dergelijke exercitie willen doorlopen. Een Eerste Kamerlid liet zich na afloop van de Oefenrechtbank ontvallen: "Nu weet ik pas waar de wet voor bedoeld is en waarvoor ik eigenlijk heb gestemd." Het opstarten van gebiedsprocessen met de kennis van de oefenrechtbank is doorlopend gaande, het werkelijk nogmaals optuigen van een oefenrechtbank, dat is tot heden niet meer gebeurd. Wel is de Coöperatieve Samenleving een halfjaar later gevraagd door het Nederlands Gesprek Centrum om in Haarlem de hele oefening nog eens toe te lichten in bijzijn van Binnenlands Bestuur, het ministerie van BZK en de opleidingsorganisatie van de rechterlijke macht etc. Het doorlopen van het proces leidde er toe dat bewoners beseften dat ze elkaar nodig hebben. En dat de gemeente beseft dat ze de burgerinbreng nodig heeft. De oplossingen en verbanden komen dan vanzelf tot stand. Door een stukje structurering in lijn met de uitspraak van de oefenrechtbank zorg je dat het bestendig is naar de toekomst toe (verbinden). Het vonnis zelf is als product vrij robuust. Het is jammer dat weinig andere gemeenten of bewoners niet eenzelfde soort experiment doen om de Omgevingswet in de vingers te krijgen. Het is echter wel begrijpelijk, vanwege de complexiteit om dit mogelijk te maken. 


\section{Project 'Vreedzaam leren en doen' van de Gebiedscoöperatie Rivierenland}

\subsection{Introductie}

De Gebiedscoöperatie Rivierenland (GCR) bestaat sinds 2014 en is opgericht als koepel van diverse burgerorganisaties in Rivierenland, gericht op bijvoorbeeld duurzame energie, vervoer, voedsel en zorg. Soms blijven samenwerkingsvormen informele netwerken en soms kiezen burgers ervoor om een officiële coöperatie (of andere juridische vorm) op te richten. De GCR vormt hiervan de koepel, die de stem van burgers in Rivierenland en daarbuiten versterkt. Burgers (inclusief kleinbedrijf en zzp'ers) willen nadrukkelijk betrokken worden in de gebiedsontwikkeling, zowel lokaal als regionaal. De GCR wil in Rivierenland een regionale circulaire economie stimuleren, die samengaat met sociale en ecologische waarden, met het doel om de welvaart en het welzijn in Rivierenland duurzaam te vergroten. De GCR verzorgt met haar Penta Helix partners de tussenruimte. De term Penta Helix partners verwijst naar de 5 O's: overheid, ondernemers, onderwijs, onderzoek en omwonenden. De tussenruimte verwijst volgens Teisman (2019) naar 'de regio die te zien is als een tussenruimte tussen organisaties die juist NIET werkt als een organisatie en daardoor in staat is om tot veranderingen te komen, die elk der participerende organisaties apart niet voor elkaar krijgt'.

De GCR behartigt de belangen van het netwerk (o.a.) in de Stuur- en Regiegroep van de RES (Regionale Energie Strategie) Rivierenland ${ }^{5}$, aan de landelijke RES-Participatietafel ${ }^{6}$ en de bestuurlijke Stuurgroep van de Regio Deal en denkt mee aan het herijken van het economisch beleid, periode 2020-2024, in Rivierenland (GCR, 2020). Vanuit de stuurgroep RES Rivierenland geeft de gebiedscoöperatie concreet invulling aan de uitgangspunten voor de RES Rivierenland ${ }^{7}$ en aan de samenwerkingsagenda ${ }^{8}$ en de integrale financiering. ${ }^{9}$ Daarnaast werkt de gebiedscoöperatie samen aan de Regiodeal en zit de gebiedscoöperatie in de fruitdelta. ${ }^{10}$

Integrale gebiedsontwikkeling is volgens de GCR een lastig onderwerp in het huidige systeem: er wordt kleinschalig en sectoraal gedacht en zo zijn ook de regelingen ingericht. Er is volgens de GCR geen vertrouwen in coöperatief werken en er heerst een cultuur van kleinschaligheid. Schijnbaar tegenstrijdige belangen zitten meervoudige verdienmodellen in de weg. Dit wordt versterkt door onvoldoende inzicht in de kwetsbaarheden en kansen van het gebied. In dit project zijn leerinstrumenten ontwikkeld (masterclasses, een voorbeeldproject, een gebiedswaardemodel en een leermodule) die burgers, de coöperatie, marktpartijen en overheden in Rivierenland kunnen gebruiken om elkaar beter te begrijpen en verstaan, waardoor ze effectiever efficiënter kunnen werken met gebiedspotentieel en meervoudig waarden kunnen oogsten. De naam van het project verwijst naar het doel: vreedzaam leren, waardoor er minder botsingen zijn tussen partijen in het gebied. De masterclasses waren vooral gericht op het beter samenwerken tussen partijen. Het gaat dan om samenwerking tussen de 5 O's, zoals die binnen RVO worden genoemd; deze staan ook centraal in de Economic Board van Rivierenland.

\footnotetext{
5 https://www.resrivierenland.nl/wie-maakt-de-res/

https://www.regionale-energiestrategie.nl/default.aspx

https://www.resrivierenland.nl/wp-content/uploads/Notitie-uitgangspunten-RES-Rivierenland.pdf

https://www.resrivierenland.nl/regionale-energiestrategie-bijeenkomst-samenwerkingsagenda/

9 https://www.overheidvannu.nl/

${ }^{10}$ https://www.fruitdelta.nl/regiodeal/
} 


\subsection{Herkennen en identificeren van small wins}

De kleine stap bestaat uit het initiatief tot het project 'Vreedzaam leren en doen' van de Gebiedscoöperatie Rivierenland (GCR), gericht op ontwikkeling leerinstrumenten (masterclasses, een voorbeeldproject, een gebiedswaardemodel en een leermodule), opdat burgers, marktpartijen en overheden in Rivierenland kunnen gebruiken om elkaar beter te begrijpen en verstaan.

De grootse winst van het project (tastbaar resultaat) is het combineren van opgaven tot meervoudige opgaven. Een ander tastbaar resultaat is dat de samenwerking in Rivierenland naar een hoger niveau is gekomen: bouwen aan het vertrouwen en met plannen focussen op regionale samenwerking.

Concreet is het volgende gerealiseerd met het project:

1. Drie masterclasses:

a. De aardgastransitie

b. Kennismaking met lokale fondsen

c. Veilig stellen van grond voor volgende generaties

2. Uitgewerkt voorbeeldtraject: Betuwewind

3. Model voor gebiedsboekhouding: verkenning van een gebiedswaardemodel

4. Minimaal een module van toolkit: masterclasses zijn op papier gezet en betrokkenen bieden zich voor anderen als sprekers aan.

Uit deze projecten kwamen ook weer andere resultaten voort. De voorzitter: "We hadden een oploop gepland in het najaar in Rivierenland. Maar we zijn nu al met participatieprocessen succesvol in het gebied ook binnen de RES (Regionale Energie Strategie). Als gebiedscoöperatie zijn we mede vormgever en invuller van het RES-programma geworden. We waren al een beetje het RESprogramma aan het doen. We worden gezien als een vertegenwoordiger van de georganiseerde samenleving. Wij hebben een ecosysteem opgebouwd van coöperaties. Die zijn maar een gedeelte van de participatieve democratie; wel een gedeelte dat verantwoordelijkheden neemt. De gebiedscoöperatie wordt gezien als centrale partij voor samenwerking tussen 5 O's. Het PTRNprogramma heeft ons geholpen om te versnellen en aan te scherpen. We zijn elkaar meer aan het versterken dan conflicten te maken. Echte samenwerking dus, al is het nog wat fragiel. De masterclasses werden als sleutelmomenten gezien."

De diepgaande verandering is dat de GCR in Rivierenland een regionale circulaire economie wil stimuleren die samengaat met sociale en ecologische waarden, met het doel om de welvaart en het welzijn in Rivierenland duurzaam te vergroten. De GCR is een koepelcoöperatie, waar andere coöperaties in Rivierenland onder vallen. De (deels) overwonnen barrières zijn als volgt toe te lichten.

Financiën. Het geld van de PTRN maakte het mogelijk om met de regio te reflecteren. De voorzitter geeft aan hoe verder financiering van de GCR gebeurt: "Wij vertegenwoordigen als GebiedsCoöperatie Rivierenland een netwerk. Vanuit een kwartiermakersrol vertegenwoordigen wij partijen. Niet rond de inhoud, maar vooral rond communicatie, bestuurlijke samenwerking, kennisuitwisseling etc. Toen zijn wij het gaan uitvoeren als koepelorganisatie, dat is uniek als gebiedscoöperatie. Wij doen dat niet betaald. Wij halen de kosten uit projecten voor onkostenvergoeding. Wij worden niet betaald. Ik zie het als een pilot: het dynamiseren van gebieden in de tussenruimte. Wij (de voorzitter en de secretaris) steken er bovengemiddeld veel tijd in: meer dan 20 uur per week." De voorzitter benadrukt het belang van gezamenlijke financiering voor het gebied: "Als gebiedscoöperatie vinden wij het belangrijk dat wij leren om samen te sturen, leren, maar ook naar gezamenlijke financiering te gaan voor het gebied, door samenwerking te komen tot risicoverkleining in het gebied. Ons doel is om geld weer voor regionale economieën in te zetten." Deze ambitie is niet gemakkelijk te realiseren: "Schijnbaar tegenstrijdige belangen zitten meervoudige verdienmodellen in de weg. Dit wordt versterkt door onvoldoende inzicht in de kwetsbaarheden en kansen van het gebied." "Andere financieringsarrangementen zijn nodig, waarbij zaken die op zich een goede businesscase hebben, worden gecombineerd met zaken die dat niet hebben. Zet in op een gebiedsfonds: een fonds dat waarde en samenwerking bij elkaar brengt en huidige gat overbrugt." 
Regelgeving. De GCR heeft verschillende ervaringen met barrières rond regelgeving. Zo wordt bestudeerd hoe de GCR andere coöperaties in Rivierenland kan financieren, zonder daarbij vast te lopen op aanbestedingsregels. Een andere ervaring betreft het omgaan met sectorale regelgeving en het ontbreken van integratiemogelijkheden: "Integrale gebiedsontwikkeling is een lastig onderwerp in het huidige systeem: er wordt kleinschalig en sectoraal gedacht en zo zijn ook de regelingen ingericht. Vaak is niet duidelijk wat integrale gebiedsontwikkeling precies inhoudt. Diverse gesprekpartners benadrukten dat onder andere een voorbeeldproject kan helpen om zichtbaar te maken wat integrale gebiedsontwikkeling precies betekent. We kijken anders naar rollen (en taken en bevoegdheden); want als de waarden van iedereen in het gebied ertoe doen, moet die ook in het creatieproces tot uitdrukking kunnen komen. Het betekent vooral dat bewoners in het gebied moeten opstaan om een rol te pakken om het gebied waardevol te maken, dat de overheid daar ruimte voor biedt en dat marktpartijen daarop ingaan spelen." Naast regelgeving heeft de GCR ook te maken met regels gesteld vanuit overheden. Een voorbeeld hiervan is de Regionale Energie Strategie (RES). De voorzitter van de GCR hierover: "De gemeenteraden nemen de beslissingen. Wij stelden vanuit de Gebiedscoöperatie Rivierenland en namens de stuurroep RES de vraag aan hen: Waar gaan wij dan op sturen? De bestuurders vonden dat een terechte vraag en vroegen hen vervolgens om met een invulling te komen van wat de rol is van de stuurgroep RES."

Overtuigingen. De voorzitter heeft verschillende overtuigingen die vooral coöperaties en gebiedsontwikkeling ondersteunen. "Mensen in Rivierenland hebben altijd hun eigen boontjes gedopt en doen dat nog steeds. Deze eigenschap is versterkt door een terugtredende overheid, een economische crisis die het falen van de markt zichtbaar gemaakt heeft en de digitale revolutie. Burgers nemen het heft op vele terreinen in eigen hand. Echter willen deze initiatieven effectief en efficiënt zijn voor het gebied en tot meervoudige waarde leiden, dan zal er meer gewerkt moeten worden vanuit een integrale gebiedsontwikkeling." Volgens de voorzitter was er geen vertrouwen in coöperatief werken en heerste er een cultuur van kleinschaligheid in Rivierenland. Zijn overtuiging is dat processen weer bij bewoners dienen te starten: "Bewoners dienen meer eigenaar te worden van processen in hun buurt. De crux daarin is dat het niet (door een externe partij) ontwikkeld wordt, maar dat het zichzelf (van binnenuit) ontwikkelt, gesteund door de overheid en door marktpartijen die erop inspelen." Mensen kunnen zich volgens de voorzitter met vier type vraagstukken verbinden: 1. Bestuurlijke vraagstukken (Hoe gaan we besluiten nemen? Wie doet wat? Hoe krijgen we de goede mensen op de goede plek?), 2. Sociale vraagstukken (Hoe krijgen we alle bewoners mee? Waarvoor willen bewoners zich inzetten? Hoe kunnen we die verlangens en behoeften zichtbaar maken? Hoe versterken we de verbindingen tussen buurtbewoners om de verschillende waarden tot uitdrukking te brengen? Hoe zorgen we ervoor dat er commitment ontstaat en dat die blijft bestaan in het proces?), 3. Ruimtelijke en technische vraagstukken (Welke fysieke mogelijkheden zijn er en wat is voor ons de beste (individuele of collectieve) oplossing?) en 4. Financiële vraagstukken (Welke waarden kunnen we met elkaar verbinden en wat levert dat geheel voor de buurt op? Wat gaat het kosten? Hoe gaan we dit betalen? Wie heeft er allemaal belang bij dat het gebeurt en wil mee investeren?).

Kennis en relaties. De voorzitter is dankbaar dat de PTRN er is. Het gaat om leren in gebiedsprocessen. Het programma van de PTRN kwam steeds weer op de governance uit en het leren. De PTRN biedt volgens hem ook inspiratie: leren van elkaars praktijken: "Een van de deelnemers aan de PTRN verzorgde bij ons een presentatie die enorm waardevol was voor Rivierenland. Dat kwam tot stand via de PTRN." De PTRN heeft volgens hem bijgedragen aan versnelling van de samenwerking in Rivierenland. Toch heeft hij ook commentaar op de werkwijze met participatietafels: "Het was duidelijk dat er een regiotafel moest komen voor transities. Wij zijn supporter geweest dat er een nieuw programma kwam. Wij hebben meteen aangegeven dat we onvoldoende begrepen waarom de tafels niet direct meer aan elkaar werden gekoppeld. Die worsteling wil ik ook wel even benoemd hebben. De PTRN heeft daarmee zijn eigen dynamiek gekregen. De koppeling tussen tafels wordt niet gemaakt vanuit de beleving van de deelnemer. Als je dat wel had gedaan, waren vraagstukken meer te verbinden geweest met de verwachting van mijn kant dat er meer quick wins mogelijk zouden zijn. Wins die je nu niet kan behalen. Het wordt wel bij RVO beleefd, maar niet bij de deelnemers. In gebieden komen alle tafels bij elkaar. Waarom kunnen ze niet binnen het programma geïntegreerd bij elkaar komen? Ik werd zelfs ergens geweigerd en het gesprek hierover kon niet gevoerd worden. Samenwerken is lastig. RVO is primair een uitvoeringsorganisatie. Binnen die organisatie zit ook diversiteit in oud en nieuw denken." 
Ook de diversiteit van de deelnemers en wisselingen binnen de PTRN vindt de voorzitter een worsteling.

Over de (deels) overwonnen barrières kunnen we concluderen dat financiering vanuit de PTRN richting de GCR bevorderend heeft gewerkt. Daarnaast proberen de initiatiefnemers de kosten te dekken uit projecten die zij aangaan. De GCR heeft de regels omtrent financiering vanuit thema's belemmerend ervaren voor integrale projecten en pleiten daarom voor een gebiedsfonds. De GCR heeft verschillende ervaringen met barrières rond regelgeving. Zo wordt bestudeerd hoe de GCR andere coöperaties in Rivierenland kan financieren, zonder daarbij vast te lopen op aanbestedingsregels. Een andere ervaring betreft het omgaan met sectorale regelgeving en het ontbreken van integratiemogelijkheden. De voorzitter heeft verschillende overtuigingen die vooral coöperaties en gebiedsontwikkeling ondersteunen. Voor kennis en relaties is de PTRN als bevorderend ervaren, maar de mogelijkheden om deel te nemen aan meerdere participatietafels als belemmerend.

De verbinding van de inhoudelijke en sociale verandering ziet de voorzitter als volgt. De inhoudelijke verandering is een regionaal circulaire economie. De sociale verandering is een menselijke economie. De coöperatie verbindt deze via haar deelnemers. De GebiedsCoöperatie Rivierenland (GCR) is een plek met energie om verder te leren en te experimenteren en stimuleert nog steeds de zelforganisatie in burgercoöperaties, die democratische legitimiteit en continuïteit bieden.

\subsection{Verspreiden, verbreden en verdiepen}

Verspreiding van het project Vreedzaam leren en doen, verliep via de PTRN, DCS (waarvan de GCR tot 2019 lid was). De betrokkenen willen als sprekers opereren voor masterclasses in andere gebieden. Verspreiding vond plaats via 'lab oogst van morgen' en via het NP RES (Nieuw Plan Regionale Energie Strategie). Van verbreding is sprake door Masterclass 1 te herhalen voor de bestuurders (colleges) in Rivierenland. Verder was het voornemen om de masterclass in het werkgebied van Gebiedscoöperatie O-gen met dezelfde opzet te herhalen, maar een bij dat gebied passende inhoud. Ook was het voornemen om in samenwerking met Gebiedscoöperatie O-gen nog een project (De Grebbelinie) uit hun werkgebied op dezelfde wijze uitwerken. Gebiedscoöperatie $\mathrm{O}$-gen is inmiddels opgeheven. Van verdieping was sprake in Masterclass 2 die vervolg kreeg in samenwerking met de Rabobank West-Betuwe, waarbij verder werd ingezoomd wat lokale fondsen voor elkaar kunnen betekenen (o.a. kennis delen) en hoe een intensievere samenwerking gestalte zou kunnen krijgen.

\subsection{Aanjaagmechanismes}

De Gebiedscoöperatie Rivierenland stimuleert nog steeds de zelforganisatie in burgercoöperaties, die democratische legitimiteit en continuïteit bieden (energizing). Er wordt veel geëxperimenteerd, zowel in nieuwe samenstellingen van betrokken actoren als bijvoorbeeld in nieuwe verdienmodellen.

De gebiedscoöperatie Rivierenland is uniek als grote koepelgebiedscoöperatie die ook nog tal van andere coöperaties in regio's als medeleden heeft. Zij pakken grote vraagstukken op die ze graag via allerlei wegen delen met andere gebieden (masterclasses etc.) (logic of attraction). Vanuit dit project is zeker een olievlekwerking waar te nemen. Ze worden uitgenodigd om elders ook masterclasses te verzorgen. De hele doelstelling van het project 'vreedzaam leren en doen' is gericht op het vermijden van belangenconflicten en het gezamenlijk verkennen van opgaven en financieringsmodellen. Daarmee zijn partijen ook letterlijk meer naar elkaar toegegroeid (verbinden).

De gebiedscoöperatie is robuust, al is de voorzitter net verhuisd naar Haarlemmermeer en is nog onduidelijk of hij een rol kan blijven vervullen. Of dit van betekenis gaat zijn voor de robuustheid van de GCR is nog onduidelijk. 


\section{Vergelijking van negen casussen}

\subsection{Negen praktijken: echte voorbeelden van small wins?}

In deze paragraaf gaan wij na in hoeverre de negen praktijken zijn te kwalificeren als small wins.

Daarvoor gebruiken we de volgende criteria:

- Tastbare resultaten voor direct betrokkenen

- Betekenisvolle stap op weg naar systeemverandering; transitie ambitie

- Diepgaande verandering/omdenken

- Wrijving ontmoet en barrières voorkomen

- Verbinding inhoudelijke en sociale verandering

- Plek met energie

Tabel 12.1 Drie praktijken als voorbeelden van small wins.

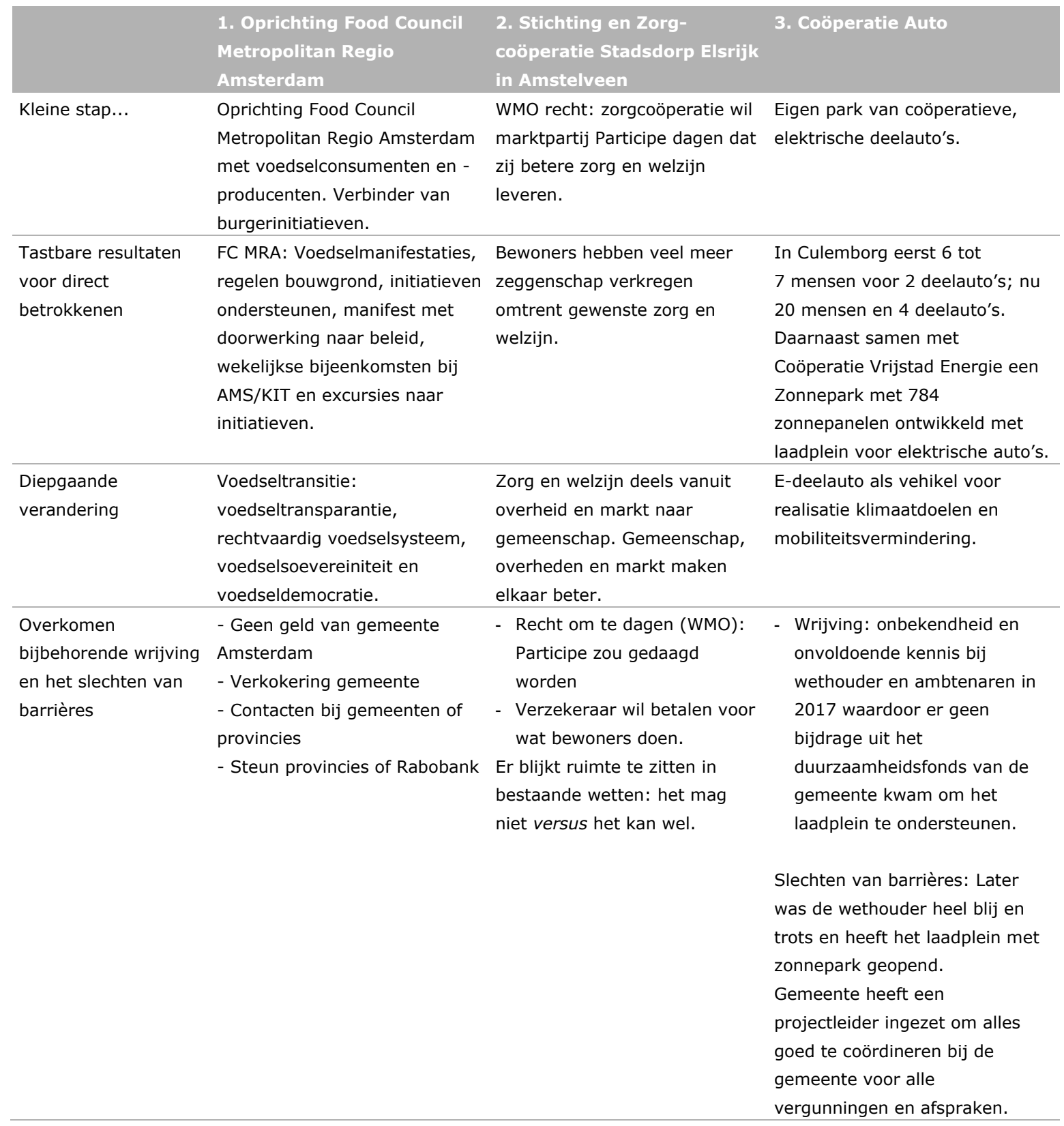


- Subsidie voor laadplein geeft nu een barrière op de E-deelauto-subsidie i.v.m. maximum staatssteun. Hierdoor kunnen we voor Edeelauto's geen subsidie meer aanvragen voor de komende 2 jaar.

- PTRN als praktijkacademie voor verwoording en procesverloop project.

- Grote ervaren afstand tussen beleidsmakers en doeners.

\section{Verbinding} inhoudelijke en sociale verandering
Inclusiviteit en sociale cohesie

bij voedseltransitie.
Instrument 'Right to challenge' leidde tot meer zeggenschap voor bewoners.

E-deelauto's bieden nieuwe gebruiksmogelijkheden/vrijheden voor mensen, doordat mensen met meerdere E-deelauto's kunnen rijden. Daarnaast zijn mooie landelijke verbindingen ontstaan tussen E-deel- Coöperaties. $\mathrm{Er}$ is veel energie om te Plek met energie om De Food Council blijft door Kennisdeling plannen en verder te experimenteren en leren. initiatieven via eigen website. experimenteren en te leren

verbreden. Komt aan verspreiden en verdiepen niet toe: middelen om landelijk de kennis te delen en te ondersteunen bij andere Coöperaties zijn niet aanwezig.

Tabel 12.2 Drie praktijken als voorbeelden van small wins.

\begin{tabular}{|c|c|c|c|}
\hline & $\begin{array}{l}\text { 4. Tafeldemocratie van } \\
\text { Vereniging Noorden } \\
\text { Duurzaam in drie pilots }\end{array}$ & $\begin{array}{l}\text { 5. Oprichting Flitscoöperatie } \\
\text { via Organisatie Lijnspel met } \\
\text { toog dialoog in Heerlen } \\
\text { centrum }\end{array}$ & $\begin{array}{l}\text { 6. Reflexieve monitoring } \\
\text { coalitie Groen verbindt in } \\
\text { Alblasserwaard- } \\
\text { Vijfheerenlanden }\end{array}$ \\
\hline Kleine stap... & $\begin{array}{l}\text { De Vereniging Noorden } \\
\text { Duurzaam wil transities in } \\
\text { netwerken versnellen door } \\
\text { tafeldemocratie, een nieuwe } \\
\text { visie op democratie en politiek, } \\
\text { vooral via omvorming van wijk- } \\
\text { en dorpsraden. Tafeldemocratie } \\
\text { is getest met DD/PTRN, in } \\
\text { Heerlen en in Wieringermeer. }\end{array}$ & $\begin{array}{l}\text { Organisatie Lijnspel } \\
\text { ondersteunt de gemeente } \\
\text { Heerlen via het organiseren van } \\
\text { een dialoog met de oprichting } \\
\text { van een energiecoöperatie voor } \\
\text { Heerlen centrum. }\end{array}$ & $\begin{array}{l}\text { Introductie van reflexieve } \\
\text { monitoring voor en vaststellen } \\
\text { van diagnose vitaliteit van } \\
\text { regionale coalitie Groen } \\
\text { Verbindt in Alblasserwaard- } \\
\text { Vijfheerenlanden via } 2 \text { trainers. }\end{array}$ \\
\hline $\begin{array}{l}\text { Diepgaande } \\
\text { verandering }\end{array}$ & $\begin{array}{l}\text { Tafeldemocratie als bestuurlijke } \\
\text { vernieuwing: een nieuw } \\
\text { functioneel democratisch } \\
\text { overlegorgaan voor } \\
\text { transitietaakverdeling, met een } \\
\text { taakvakkenstructuur en } \\
\text { kerntakenmodel. }\end{array}$ & $\begin{array}{l}\text { Betrekken van meer mensen bij } \\
\text { duurzaamheidsthema's leidt tot } \\
\text { meer verantwoordelijkheid. } \\
\text { Meer partijen krijgen } \\
\text { zeggenschap op leefbaarheid. } \\
\text { Dat levert een andere } \\
\text { dynamiek op. }\end{array}$ & $\begin{array}{l}\text { - Meerwaarde inzien van leren } \\
\text { door reflectie en condities } \\
\text { hiervoor. } \\
\text { - Inzicht in effecten van } \\
\text { interventies door } \\
\text { vernieuwers, inspirators en } \\
\text { verbinders die inspelen op }\end{array}$ \\
\hline
\end{tabular}


overtuigingen, waarden en gevoelens.

$\begin{array}{ll}\text { Overkomen } & \text { Oude wijkraden en } \\ \text { bijbehorende wrijving } & \text { gemeenteraden beschermen } \\ \text { en het slechten van } & \text { hun posities/status. }\end{array}$

en het slechten van barrières
Niet te snel willen: paaltje met - Weerstanden bij overheden vorst in de grond slaan, breekt. zitten vooral in de sectorale Zachte tikjes.

dossiervorming

(verkokering)

- Tijdsdruk bij overheden leidt tot missen leerhouding

Regionale duurzaamheid via integrale aanpak en regionaal inhoudelijke en Tafeldemocratie als Lijnspel/Toog dialoog nam inhoudelijke verandering is een sociale verandering overleg- en bestuursvorm die kan leiden tot sociale verandering: meer transparantie, zeggenschap, openbaarheid, controle. Zou behalve tot transitieversnelling ook tot betere democratie moeten leiden

Plek met energie om De kaarten in de tafelatlas verder te experimenteren en te leren van openbaar bestuur met daarin de gebiedstafel als schetsen een toekomstbeeld nieuw parlementair orgaan. Deze beeldvorming is bedoeld om debat, leren en nieuwe experimenten te bevorderen.

initiatief om huiseigenaren, pandbezitters, ondernemers en commitment oppakken. bewoners in het centrum bij elkaar te brengen en enthousiast te maken voor zonnedaken. Beslisstructuur voor vorm coöperatie en verdeling van winst uit energie. zijn geweest.

De nieuwe coöperatie in oprichting bruist van de energie. Er zijn plannen in de maak waar ze zo 1,5 jaar mee vooruit kunnen.
Inhoudelijke verandering is regionaal programma voor Alblasserwaard-

Vijfheerenlanden waarbij de 4 reflectiemiddagen voedend In de regio AlblasserwaardVijfheerenlanden blijft men openstaan voor vernieuwing.

Tabel 12.3 Drie praktijken als voorbeelden van small wins.

\begin{tabular}{|c|c|c|c|}
\hline & $\begin{array}{l}\text { 7. Coöperatie } \\
\text { Bommelerwaar in de } \\
\text { Bommelerwaard }\end{array}$ & $\begin{array}{l}\text { 8. Oefenrechtbank Notter } \\
\text { Zuna in Wierden }\end{array}$ & $\begin{array}{l}\text { 9. Vreedzaam leren en doen } \\
\text { via de Gebiedscoöperatie } \\
\text { Rivierenland (GCR) }\end{array}$ \\
\hline
\end{tabular}

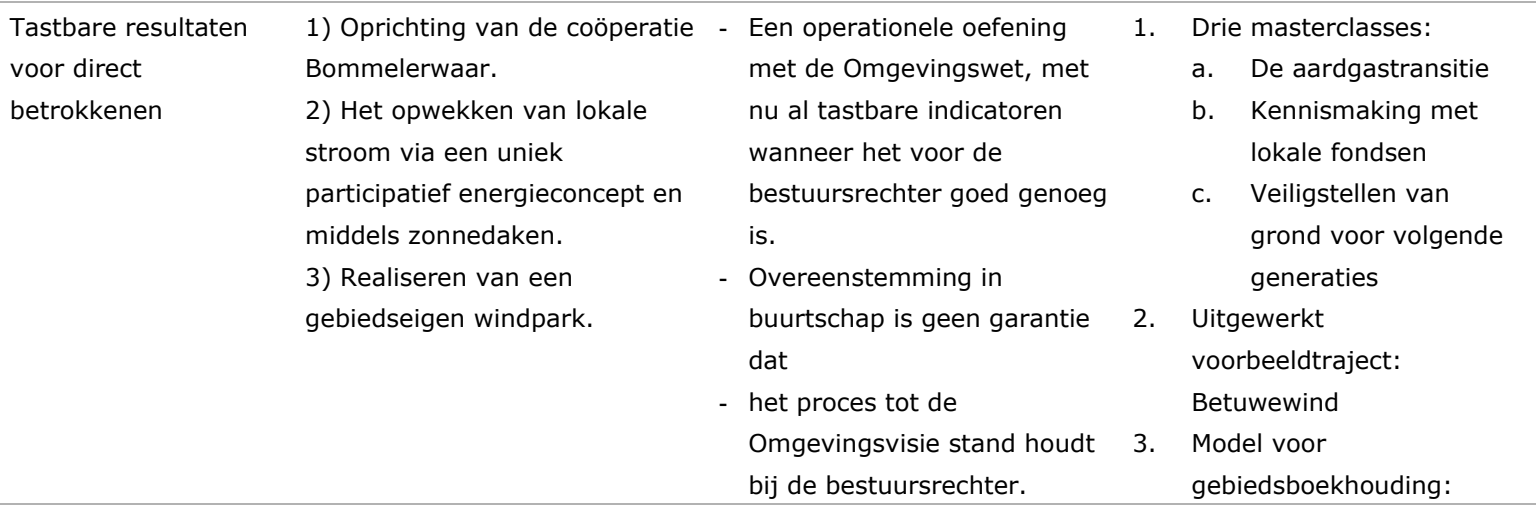




\begin{tabular}{|c|c|c|c|}
\hline & $\begin{array}{l}\text { 7. Coöperatie } \\
\text { Bommelerwaar in de } \\
\text { Bommelerwaard }\end{array}$ & $\begin{array}{l}\text { 8. Oefenrechtbank Notter } \\
\text { Zuna in Wierden }\end{array}$ & $\begin{array}{l}\text { 9. Vreedzaam leren en doen } \\
\text { via de Gebiedscoöperatie } \\
\text { Rivierenland (GCR) }\end{array}$ \\
\hline & & $\begin{array}{l}\text { - Heldere minimumcriteria } \\
\text { van de bestuursrechter over } \\
\text { functietoedeling, integraliteit, } \\
\text { participatieproces en } \\
\text { zorgvuldige } \\
\text { belangenafweging en } \\
\text { compensatie in het proces. }\end{array}$ & $\begin{array}{l}\text { verkenning van een } \\
\text { gebiedswaardemodel. } \\
\text { Minimaal een module van } \\
\text { toolkit: masterclasses zijn } \\
\text { op papier gezet en } \\
\text { betrokkenen bieden zich } \\
\text { voor anderen als sprekers } \\
\text { aan. }\end{array}$ \\
\hline $\begin{array}{l}\text { Diepgaande } \\
\text { verandering }\end{array}$ & $\begin{array}{l}\text { Ontwikkeling van een publiek- } \\
\text { burgerlijk-privaat } \\
\text { gebiedsgovernance-model } \\
\text { vanuit participatie, } \\
\text { gezamenlijke legitimiteit, } \\
\text { zeggenschap en } \\
\text { aansprakelijkheid. } \\
\text { Begin maken in de praktijk van } \\
\text { een inclusief, gebieds- } \\
\text { economisch model gericht op } \\
\text { gebiedswaarde ('van, voor en } \\
\text { door het gebied' in termen van } \\
\text { zowel gebruik als eigendom). }\end{array}$ & $\begin{array}{l}\text { Bewustwording bij alle partijen } \\
\text { van overheid, burgers, boeren, } \\
\text { mkb, zzp en de grotere } \\
\text { bedrijven van de } \\
\text { systeemomslag die met de } \\
\text { invoering van de Omgevingswet } \\
\text { eraan komt. } \\
\text { Inzetten op inclusiviteit i.p.v. } \\
\text { uitsluiting. } \\
\text { Besef van urgentie bij } \\
\text { bestuurlijke vernieuwing, } \\
\text { vertrouwen, durven loslaten. } \\
\text { Ervaren dat weerbarstige } \\
\text { vraagstukken leiden naar } \\
\text { werkbare oplossingen door } \\
\text { cocreatie. }\end{array}$ & $\begin{array}{l}\text { De GCR is een } \\
\text { koepelcoöperatie, waar andere } \\
\text { coöperaties in Rivierenland } \\
\text { onder vallen. } \\
\text { De GCR wil in Rivierenland een } \\
\text { regionale circulaire economie } \\
\text { stimuleren die samen gaat met } \\
\text { sociale en ecologische waarden, } \\
\text { met het doel om de welvaart en } \\
\text { het welzijn in Rivierenland } \\
\text { duurzaam te vergroten. }\end{array}$ \\
\hline $\begin{array}{l}\text { Overkomen } \\
\text { bijbehorende wrijving } \\
\text { en het slechten van } \\
\text { barrières }\end{array}$ & $\begin{array}{l}\text { - Echte vernieuwing vraagt } \\
\text { een nieuwe houding } \\
\text { ondersteund door een } \\
\text { gestructureerd leerproces; } \\
\text { het goeddeels ontbreken } \\
\text { daarvan beperkte de } \\
\text { meebeweegkracht van } \\
\text { achterban } \\
\text { - Overwinnen } \\
\text { systeemweerstand t.a.v. } \\
\text { burgerparticipatie en } \\
\text { windmolens: fel anti-college } \\
\text { in } 2 \text { maanden naar uniform } \\
\text { positief oordeel } \\
\text { gemeenteraad. } \\
\text { - Met zeer beperkte } \\
\text { (financiële) middelen toch } \\
\text { iets moois neerzetten. }\end{array}$ & $\begin{array}{l}\text { - Wanneer is het integrale } \\
\text { proces goed genoeg volgens } \\
\text { de Omgevingswet? } \\
\text { - Schuiven als team: } \\
\text { bestuurlijke vernieuwing en } \\
\text { het leren omgaan met de } \\
\text { horizontale } \\
\text { verantwoordelijkheid. } \\
\text { - Vasthouden aan oude } \\
\text { verticale governance was } \\
\text { dodelijk geweest. }\end{array}$ & $\begin{array}{l}\text { - } \text { Kennisdeling PTRN } \\
\text { - De starre opdeling tussen } \\
\text { tafels bij PTRN. }\end{array}$ \\
\hline $\begin{array}{l}\text { Verbinding } \\
\text { inhoudelijke en } \\
\text { sociale verandering }\end{array}$ & $\begin{array}{l}\text { Energie was als starter/motor } \\
\text { bedoeld om proces met publiek, } \\
\text { particulier (burgers) en privaat } \\
\text { aan te jagen. Vanuit energie } \\
\text { breder willen trekken naar } \\
\text { mobiliteit, voedsel, zorg, wonen } \\
\text { etc. Is nog niet gelukt. Niet dat } \\
\text { men niet wilde verbreden of } \\
\text { leren. Het is heel veel werk en } \\
\text { kwamen daarmee aan een } \\
\text { gestructureerd leerproces } \\
\text { onvoldoende toe - is leerpunt } \\
\text { an sich: niet alles tegelijk. }\end{array}$ & $\begin{array}{l}\text { De inhoudelijke verandering is } \\
\text { de gebiedsgerichte integrale } \\
\text { procesvoering tot de } \\
\text { gebiedsvisie volgens de te } \\
\text { introduceren Omgevingswet. } \\
\text { De sociale verandering is de } \\
\text { benodigde cultuurverandering. } \\
\text { Het gebied is je (t)huis: dan } \\
\text { kan er veel en ook gezamenlijk } \\
\text { geleerd worden. }\end{array}$ & $\begin{array}{l}\text { De inhoudelijke verandering is } \\
\text { een regionaal circulaire } \\
\text { economie. De sociale } \\
\text { verandering is een menselijke } \\
\text { economie. De coöperatie } \\
\text { verbindt deze via haar } \\
\text { deelnemers. }\end{array}$ \\
\hline
\end{tabular}




\begin{tabular}{|c|c|c|c|}
\hline & $\begin{array}{l}\text { 7. Coöperatie } \\
\text { Bommelerwaar in de } \\
\text { Bommelerwaard }\end{array}$ & $\begin{array}{l}\text { 8. Oefenrechtbank Notter } \\
\text { Zuna in Wierden }\end{array}$ & $\begin{array}{l}\text { 9. Vreedzaam leren en doen } \\
\text { via de Gebiedscoöperatie } \\
\text { Rivierenland (GCR) }\end{array}$ \\
\hline & & $\begin{array}{l}\text { Het traject met de } \\
\text { oefenrechtbank heeft veel } \\
\text { interesse opgewekt door het } \\
\text { hele land en op alle niveaus in } \\
\text { samenleving, overheid, markt } \\
\text { en kenniswereld. }\end{array}$ & \\
\hline
\end{tabular}

\section{Eerste stappen}

In alle initiatieven of projecten zijn eerste stappen gezet. Uit de initiatieven blijkt dat dit geen gemakkelijke stappen waren en dat zich vaak al meteen barrières voordeden om deze eerste stappen te zetten. Alle initiatieven zijn gestart als goede voorbeelden van een small win. Uiteraard is een small win niet het doel van de initiatieven. De initiatieven zijn opgezet om tot diepgaande veranderingen te komen.

\section{Tastbare resultaten}

Alle projecten tonen tastbare resultaten. Bij de vraag naar tastbare resultaten ontstaat er af en toe met de deelnemers van de PTRN ook een meer fundamentele discussie over evalueren van de PTRNprojecten en de tastbare resultaten. Hierbij benadrukken de deelnemers het unieke karakter van de PTRN. De PTRN zet in op reflectief evalueren met betrokkenen. Alle participatietafels van RVO zijn anders opgezet qua samenstelling en werkwijze. Enkele deelnemers van de PTRN vragen zich af of evaluaties van de participatietafels daarmee ook verschillend worden opgezet. De vraag is ook of er wordt geëvalueerd om te verantwoorden of om van te leren. Als het gaat om verantwoorden, is de vraag belangrijk wat de PTRN oplevert en wat hierbij het referentiekader is. Wat komt uit de PTRN voort voor Nederland? Wie 'verantwoordt' zich naar wie en hoe: uniform of verschillend? Of is er een verschuiving van een overheid die zich dient te verantwoorden naar een meer reflexieve overheid: zelf leren en monitoren?

Vanuit de PTRN is besloten om na te gaan of er small wins zijn te constateren en of er aanjaagmechanismen zijn toe te passen. Dit gebeurde gezamenlijk met de PTRN-deelnemers. Het onderzoek om de small wins in beeld te brengen is nu uitbesteed aan onderzoekers vanbuiten af. Het onderzoek had volgens een deelnemer misschien ook nog meer een reflexieve zelfevaluatie kunnen zijn: "In de systeemwereld wordt misschien nog veel waarde gehecht aan een onafhankelijk oordeel vanbuiten af... het is nu misschien nog een traditionele benadering vanbuiten af om te bezien of je je werk goed doet...".

De deelnemers van de PTRN wijzen erop dat tastbare resultaten voor de verschillende participatietafels op verschillende manieren zijn in te vullen. Het gevoel daarbij is dat dit voor de inhoudelijke participatietafels, die goed verankerd zijn in de systeemwereld, gemakkelijker is te benoemen dan voor de PTRN. De deelnemers aan de PTRN bestaan veelal uit procesadviseurs en zzp'ers. De PTRN wordt gezien als een vrijplaats om met elkaar gedachten te delen. De deelnemers werken niet vanuit één gezamenlijke theorie, maar houden vast aan eigen theorieën en methoden, 
tegelijkertijd hebben ze wel een heel sterk gezamenlijk gevoel en inhoudelijke thema's die zij allen een warm hart toedragen. Small wins is een pluriform concept van waaruit verschillen in aanpak en theorie positief worden gewaardeerd. De bindende inhoudelijke thema's van de PTRN-leden richten zich naar eigen zeggen vooral op de leefwereld, waarbij gekeken wordt hoe die zich op een nieuwe manier kan verhouden tot de systeemwereld. In dit laatste gaat veel tijd en energie zitten (anders dan bij de andere participatietafels die vaak al deel uitmaken van de systeemwereld, wat het behalen van de inhoudelijke resultaten bespoedigd). Bij de PTRN gaat relatief veel aandacht uit naar thema's als:

- nieuwe economie

- positie en verhouding van gemeenschap of coöperaties tot markt en overheden

- processen van in- en uitsluiting

- sociale innovatieprocessen

- oriëntaties op het wereldsysteem (inclusief globalisering)

- Ieren

- de vijf O's betrekken: overheden, ondernemers, onderwijs/onderzoek, omgeving en organisaties (maatschappelijke)

$\mathrm{Bij}$ het vragen naar de tastbare resultaten (tastbare middelen met groot effect) geven de deelnemers van de PTRN ook meteen reflectie terug waarin een bepaalde ondertoon doorklinkt: zijn we niet te veel gericht op inhoudelijke resultaten? Is er geen mismatch op verwachte resultaten en doen we wel wat echt nodig is? Wat is nodig om kwetsbare niveau te pakken? Deelnemers aan de PTRN hebben het gevoel bij het stellen van de vraag om tastbare resultaten weer te geven, dat de PTRN dient te verantwoorden naar RVO of naar het Rijk wat de inhoudelijke resultaten zijn. Tijd is hierbij ook een belangrijke factor: wanneer moet het resultaat tastbaar zijn? Meermalen geven deelnemers aan de PTRN aan dat de tastbare resultaten vooral zijn uit te drukken in termen van mentale ruimte weten te bieden en de bereidheid om te leren. Het grootste tastbare resultaat van de PTRN zou zijn dat het een kantelpunt biedt in zelfbeelden of zoals een geïnterviewde het verwoordde: "Zijn wij alleen uitvoeringskonijnen of leren wij iets van de vragen waar we mee geconfronteerd worden? Dat zijn systeemvragen die de systeemdoelen overstijgen. Het heeft te maken met mind shift. Daar draagt de PTRN aan bij."

Bij de tastbare resultaten valt ook vaak op dat er eerst qua organisatiegraad steeds (nog) veel dient te gebeuren. Bijvoorbeeld: eerst een coöperatie opzetten die nodig is om inhoudelijk resultaat te gaan boeken. Er gaat daarmee al veel tijd en energie zitten in het organiseren van de middelen waarmee uiteindelijk inhoudelijke doelen worden nagestreefd.

Bij de resultaten zijn de persoonlijke en relationele veranderingen minder direct waarneembaar. Dit zijn ook resultaten van een andere aard dan de fysieke inhoudelijke veranderingen of resultaten. Dat wil niet zeggen dat het geen diepgaande resultaten zijn.

De PTRN levert veel meer op dan wij als onderzoekers in eerste instantie vermoedden in termen van ervaringen delen, samen leren en elkaars expertise benutten.

\section{Beoogde diepgaande verandering}

De beoogde diepgaande veranderingen zijn per project verschillend. Veelal hebben ze betrekking op duurzaamheid, bestuurlijke vernieuwing, nieuwe economie, positie en verhouding van gemeenschap of coöperaties tot markt en overheden, processen van in- en uitsluiting en sociale innovatieprocessen. Die diepgaande veranderingen zijn eindbeelden van de transitie en het zal dan ook geen verbazing wekken dat de beoogde diepgaande veranderingen nergens volledig gerealiseerd zijn. Diepgaande verandering kan pas vaak na lange tijd merkbaar worden. Dit aspect van projecten is daarom vaak alleen als ambitie in kaart te brengen.

\section{Omgaan met barrières}

Het overkomen van bijbehorende wrijving en het slechten van barrières is deels gelukt en deels ook niet. Evenals in eerdere studies (refs) hebben in dit onderzoek alle cases veel barrières ontmoet bij de eerste small wins die ze allemaal hebben overwonnen door een combinatie van missie, energie, doorzettingsvermogen en gunfactor. Steun vanuit een bepaalde persoon of organisatie binnen de overheid bleek daarbij ook belangrijk, niet alleen voor financiering, maar ook voor inhoudelijk sparren 
en aanmoediging. De deelnemers aan de PTRN noemen meermalen de PTRN als doorslaggevende factor waardoor de barrières zijn overwonnen.

Evenals in eerdere studies (Termeer, 2017; Termeer 2018) is ook hier te zien dat na de eerste small win de barrières eerder groter dan kleiner worden. Daar zijn ook in deze casussen belangrijke redenen voor te vinden:

- Financieringsbehoefte verandert: behoefte aan budgetten nemen toe bij toenemende ambities. Tijdelijke, kortstondige financieringsbehoeften veranderen in meerjarige financieringsbehoeften. Daarnaast betekent het permanent regelen dat regelingen aangepast dienen te worden of dat initiatieven vastlopen op bestaande regelgeving, bijvoorbeeld staatssteun.

- Spanningen met bestaande regelgeving worden veel dominanter en veelzijdiger: als initiatieven de experimenteerstatus voorbij proberen te komen en hun initiatieven willen verspreiden, verbreden en verdiepen, dan stuiten deze initiatieven vaak ook tegen bestaande regelgeving.

- De overtuigingen van de initiatiefnemers zijn vernieuwend en vooral ook afwijkend te noemen van de overtuigingen binnen de bestaande instituties. Het kost daarmee tijd en energie om sympathie binnen bestaande instituties te krijgen voor nieuwe overtuigingen. Naarmate initiatieven meer verspreiden, verbreden of verdiepen, zullen meer mensen in andere instituties overtuigd dienen te worden en lopen initiatiefnemers tegen meer beperkende overtuigingen aan.

- Om de businessmodellen sluitend te krijgen, zijn voldoende middelen nodig in termen van bijvoorbeeld arbeidskrachten, vrijwilligers. Dit vergt vaak een professionele opschaling van organisatievormen. Andere, opgeschaalde organisatievormen vergen een professionaliseringsslag die vaak extra middelen vergen. Als die middelen er niet zijn, is dit vaak niet mogelijk.

- Kennis en relaties worden door veel initiatieven nu binnen de PTRN aangegaan. Als de PTRN niet geborgd wordt en geen robuustheid kan bieden, wordt bij een aantal initiatieven die organisatorisch nog onvoldoende zijn ingebed, gevreesd.

\section{Verbinding inhoudelijke en sociale verandering}

In alle projecten is sprake van een verbinding tussen een inhoudelijke en een sociale verandering. De transities worden niet alleen als technisch inhoudelijk opgevat, maar in deze casussen wordt onderkend dat ook of juist sociale transitie nodig is. Naast het aanleggen van zonnepanelen als inhoudelijke verandering worden bijvoorbeeld coöperaties opgericht, een sociale verandering.

\section{Plekken met energie}

De initiatieven zijn allemaal plekken om verder te leren en te experimenteren. Het zijn goede projecten, maar zijn niet allemaal aan te merken als small wins volgens alle criteria uit hoofdstuk 2 .

\subsection{De negen praktijken verder brengen}

In deze paragraaf geven we aan hoe de negen praktijken verder zijn te brengen door te:

- Verspreiden: innovatie opschalen of uitrollen door deze ook elders toe te passen;

- Verbreden: innovatie toepassen op andere terreinen en verbinden met andere vraagstukken;

- Verdiepen: innovatie nog radicaler maken.

Met de zwarte kleur is aangegeven wat is gerealiseerd. Met de licht blauwe kleur zijn ambities aangegeven (die dus nog niet zijn gerealiseerd). 
Tabel 12.4 Negen casussen: realisatie en ambities voor verspreiden, verbreden en verdiepen.

\begin{tabular}{|c|c|c|c|}
\hline Casussen & Verspreiden & Verbreden & Verdiepen \\
\hline $\begin{array}{l}\text { 2. Right to challenge in Elsrijk } \\
\text { in Amstelveen }\end{array}$ & $\begin{array}{l}\text { - Amstelveen wil graag } \\
\text { verspreiding zien naar } \\
\text { andere wijken van } \\
\text { Amstelveen } \\
\text { - Via voorzitter van NL zorgt } \\
\text { voor elkaar wordt } \\
\text { voorbeeld Elsrijk } \\
\text { uitgedragen naar } \\
100 \text { andere zorginitiatieven }\end{array}$ & $\begin{array}{l}\text { - Ambities: } \\
\text { - diversificatie } \\
\text { - jonge generaties } \\
\text { betrekken, anderen die } \\
\text { zorg nodig hebben } \\
\text { - andere sociaal } \\
\text { ondernemers benaderen: } \\
\text { viraal uitrollen om te } \\
\text { verdienen }\end{array}$ & $\begin{array}{l}\text { - Ambitie: Verkenning } \\
\text { vormgeving kwaliteitsmix } \\
\text { van overheden, markt en } \\
\text { coöperaties. Controle: } \\
\text { elkaar beter, efficiënter } \\
\text { maken met andere } \\
\text { producten } \\
\text { - andere technieken, andere } \\
\text { democratie: domotica } \\
\text { - Right to challenge in } \\
\text { Wro/Om-gevingswet }\end{array}$ \\
\hline 3. CoöperatieAuto & 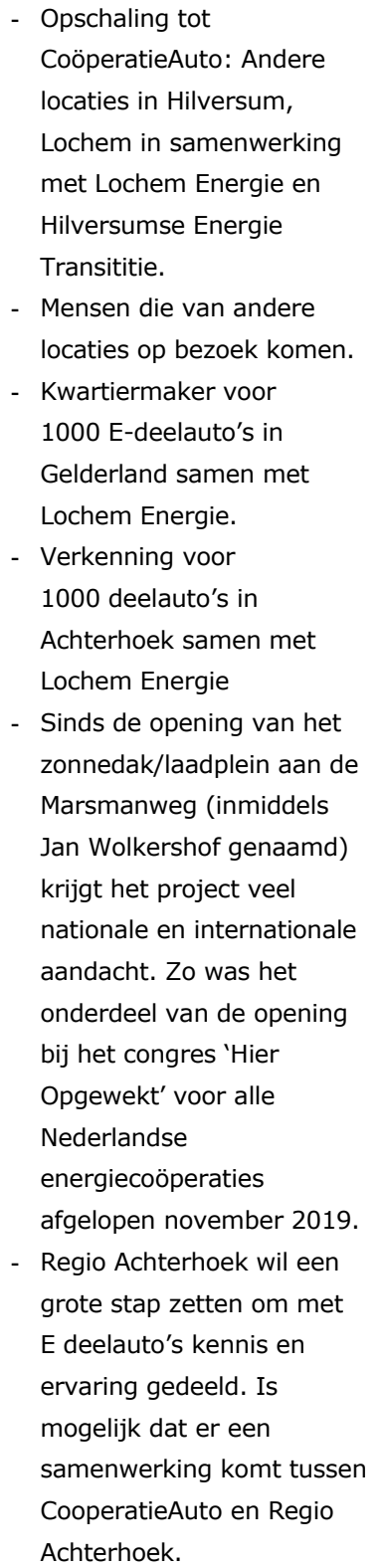 & $\begin{array}{l}\text { Ambities: } \\
\text { Het idee kan ook op de } P+R \text { 's } \\
\text { bij stations en op } \\
\text { parkeerterreinen bij } \\
\text { winkelcentra worden } \\
\text { gerealiseerd (is nog niet } \\
\text { gebeurd). } \\
\text { Laadplein voor deelauto's ook } \\
\text { beschikbaar maken als } \\
\text { energieleverancier voor de } \\
\text { wijk. } \\
\text { Andersom: energie dat } \\
\text { overblijft van windenergie } \\
\text { voor deelauto's inzetten. } \\
\text { Doel is om het concept in alle } \\
30 \text { regionale energie strategie } \\
\text { Regio's te gaan in zetten. }\end{array}$ & $\begin{array}{l}\text { Doorontwikkelen van } \\
\text { laadplein voor meer capaciteit } \\
\text { en doorontwikkelen van } \\
\text { digitale cloudboxbakjes in } \\
\text { E-deelauto's vanwege } \\
\text { aanpassingen in G-netwerk en } \\
\text { slimme laadmogelijkheden } \\
\text { met E-deelauto's. } \\
\text { Ambities: } \\
\text { Verder uitdenken van een E- } \\
\text { hubstation waarbij alle } \\
\text { verkeersmodaliteiten } \\
\text { elektrisch zijn. } \\
\text { Nagaan hoe bedrijven en } \\
\text { organisatie kunnen aansluiten } \\
\text { om een bijdrage te leveren } \\
\text { met E deelauto's aan de } \\
\text { klimaatdoelstellingen } \\
\text { Nagaan met overheden om te } \\
\text { stimuleren hoe het voor } \\
\text { burger en organisatie } \\
\text { te doen aan E-deelauto rijden. }\end{array}$ \\
\hline
\end{tabular}




\begin{tabular}{|c|c|c|c|}
\hline Casussen & Verspreiden & Verbreden & Verdiepen \\
\hline $\begin{array}{l}\text { 4. Tafeldemocratie van } \\
\text { Vereniging Noorden } \\
\text { Duurzaam in drie pilots: } \\
\text { PTRN, Heerlen en } \\
\text { Wieringermeer }\end{array}$ & $\begin{array}{l}\text { Drenthe: dorpsraden in onder } \\
\text { andere de Groningse wijken } \\
\text { Hoogkerk en Vinkhuizen } \\
\text { wordt verkend. } \\
\text { - Opzet is om te verspreiden } \\
\text { naar dorps- en wijkraden als } \\
\text { potentiële kraamkamers voor } \\
\text { democratie. Deze verspreiding } \\
\text { moet nog tot stand komen. } \\
\text { Hoogleraar in Zuid-Afrika doet } \\
\text { vergelijkbare dingen omtrent } \\
\text { vraagstelling maar totaal } \\
\text { andere aanpak. Reflecteren } \\
\text { op elkaar. }\end{array}$ & $\begin{array}{l}\text { Tafeldemocratie is eerder in } \\
\text { de bouw toegepast, voor de } \\
\text { ontwikkeling van } \\
\text { ketenconvenanten. Een } \\
\text { nieuwe vorm zijn online- } \\
\text { bouwpanels. } \\
\text { Toepassing kan verder bij } \\
\text { circulaire economie, via } \\
\text { ketentafels, om } \\
\text { samenwerking tussen } \\
\text { branches te organiseren. }\end{array}$ & $\begin{array}{l}\text { Nu nog rudimentair. } \\
\text { - Modelstatuut voor } \\
\text { tafeldemocratie opstellen: } \\
\text { lidmaatschap, toetreding. } \\
\text { - Hoe om te gaan met } \\
\text { overlappende } \\
\text { vertegenwoordiging? } \\
\text { - Omgang met verschillende } \\
\text { identiteiten en } \\
\text { gemeenschappelijke } \\
\text { taalontwikkeling }\end{array}$ \\
\hline $\begin{array}{l}\text { 5. Toogdialoog van } \\
\text { Organisatie Lijnspel om } \\
\text { Flitscoöperatie (energie) op te } \\
\text { richten }\end{array}$ & $\begin{array}{l}\text { Toog Dialoog als methode } \\
\text { uitdragen naar Heeg en naar } \\
\text { FC Metropool Regio } \\
\text { Amsterdam. } \\
\text { Ambitie: Heerlen wil graag } \\
\text { verspreiding zien naar andere } \\
\text { wijken van Heerlen. } \\
\text { Financieel model verspreiden } \\
\text { bij sportverenigingen en } \\
\text { carnavalsverenigingen }\end{array}$ & $\begin{array}{l}\text { - Opzetten van Food Council } \\
\text { - Via zonnepanelen, } \\
\text { zeggenschap leefomgeving } \\
\text { - Deelauto's wordt verkend } \\
\text { - Transformatie steden of } \\
\text { nieuwbouw > gevolgen } \\
\text { voor zonne-energie }\end{array}$ & $\begin{array}{l}\text { Ambitie: } \\
\text { Combinaties maken tussen } \\
\text { zonne-energie en verwarmen } \\
\text { van waterstromen. Alles wat } \\
\text { je opwekt ook afzetten: is het } \\
\text { meest rendabel. }\end{array}$ \\
\hline 7. Coöperatie Bommelerwaar & $\begin{array}{l}\text { - Concept Bommelerwaar- } \\
\text { Stroom binnenkort voor } \\
\text { duizenden lokale } \\
\text { huishoudens } \\
\text { - Ook lid van De } \\
\text { Coöperatieve Samenleving } \\
\text { (DCS) } \\
\text { - Via o.a. Coöperatie } \\
\text { Lingewaar en diverse } \\
\text { andere gebiedsgerichte } \\
\text { coöperaties aangesloten bij } \\
\text { DCS } \\
\text { - Via HierOpgewekt en } \\
\text { andere landelijke } \\
\text { netwerken }\end{array}$ & $\begin{array}{l}\text { Verbreding nog niet goed } \\
\text { gelukt, waren voornemens } \\
\text { richting mobiliteit, zorg, } \\
\text { wonen en voedsel (zie ook } \\
\text { logo). Strategische focus: } \\
\text { eerst iedereen met een } \\
\text { energierekening meenemen } \\
\text { (= iedereen). }\end{array}$ & $\begin{array}{l}\text { Meer investeren in } \\
\text { professionalisering, gelijke } \\
\text { houding en waarden, } \\
\text { gemeenschapsontwikkeling. }\end{array}$ \\
\hline
\end{tabular}




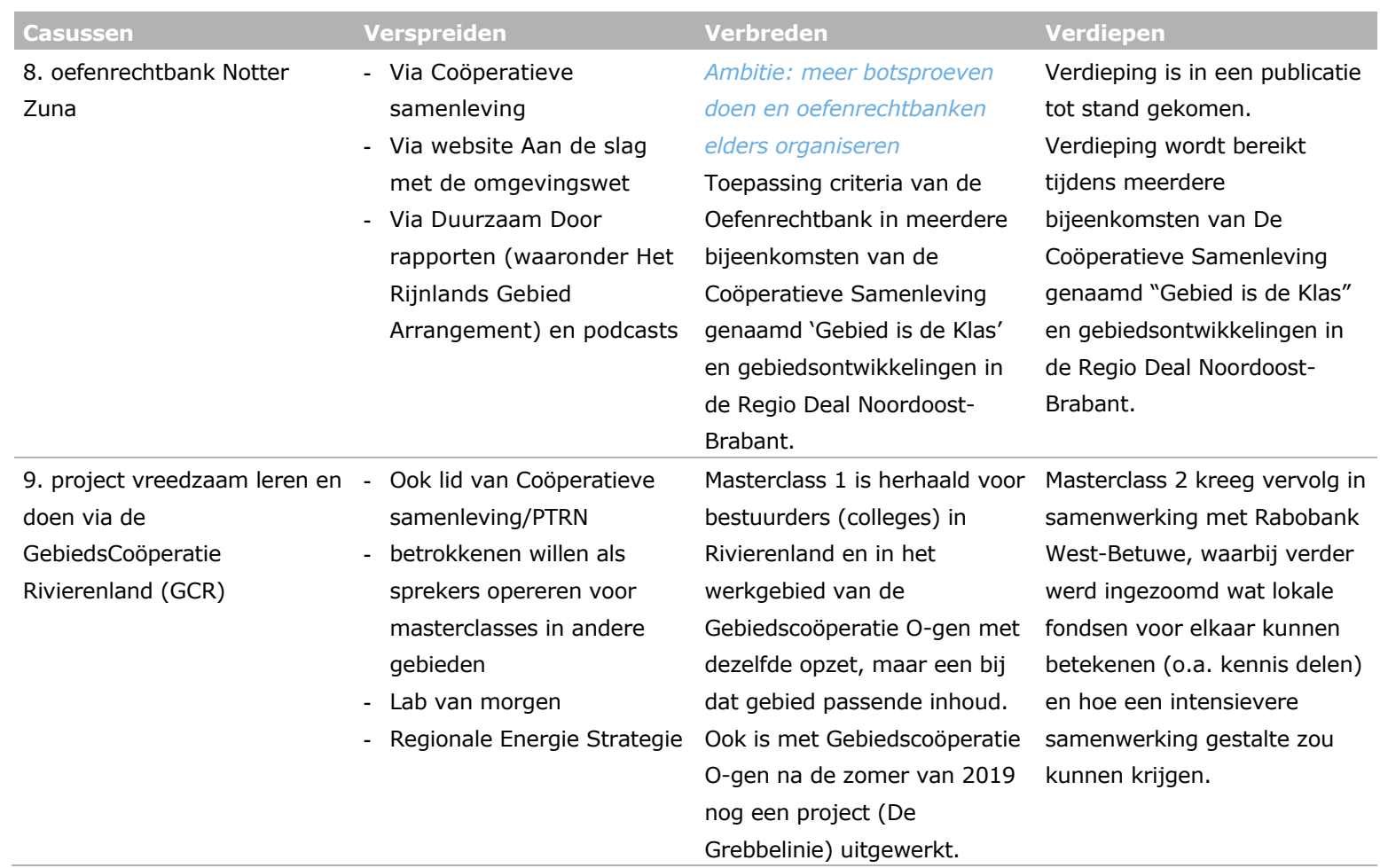

Inmiddels zijn de initiatieven allemaal deels verspreid, verbreed en verdiept of zijn hier ambities toe. Omtrent het verspreiden valt op dat de verschillende ontwikkelde theorieën en methoden niet op heel veel andere plekken worden toegepast. We zien het experimenteren en leren terug op een paar plekken. Er is meer sprake van sociale theorieën op een paar locaties toetsen. Bij het verbreden is te zien dat dit in de helft van de gevallen lukt en in de helft van de gevallen nog ambitie blijft. Omtrent het verdiepen valt op dat het vooral om ambities gaat en dat deze in bijna alle cases nog niet zijn gerealiseerd. Uit de tabel is op te maken dat het verspreiden, verbreden en verdiepen van de initiatieven nog wat tegenvalt. Er zijn wel ambities op dat vlak (weergegeven in de lichtblauwe kleur), maar de energie en tijd ontbreken blijkbaar om de ambities ook daadwerkelijk te realiseren.

Daarmee kan geconcludeerd worden dat binnen de PTRN dus eigenlijk vooral sprake is geweest van enkelvoudige small wins en nog niet van grote series van small wins. De aanjaagmechanismes zouden vanuit de small win-benadering moeten leiden tot grotere series van small wins.

\subsection{Handelingsperspectieven en aanjaagmechanismes voor accumulatie van small wins}

Richting overheden in het algemeen en de PTRN zijn al aanjaagmechanismes uit eerdere studies naar small wins te benoemen die ook van toepassing zijn op de bestudeerde cases. Die aanjaagmechanismes tonen we eerst in twee tabellen om vervolgens bij een tabel stil te staan die de handelingsperspectieven voor de PTRN in het bijzonder weergeeft. 
Tabel 12.5 Bevorderende en beperkende (overheids)interventies (Termeer et al., 2019).

\begin{tabular}{|c|c|c|c|}
\hline $\begin{array}{l}\text { Aanjaag- } \\
\text { mechanismes }\end{array}$ & Beschrijving & Bevorderende (overheids)interventies & $\begin{array}{l}\text { Beperkende (overheids) } \\
\text { interventies }\end{array}$ \\
\hline Energizing & $\begin{array}{l}\text { Zichzelf versterkend } \\
\text { proces van } \\
\text { commitment, } \\
\text { optimisme en } \\
\text { vertrouwen in elkaar } \\
\text { en in de resultaten. }\end{array}$ & $\begin{array}{l}\text { - Sparring partner zijn, meedenken, } \\
\text { waarderen. } \\
\text { - } \text { Respect voor de relatie tussen het } \\
\text { kleine initiatief en het bevlogen } \\
\text { langetermijnverhaal. } \\
\text { - Vertrouwen geven. Laten zien dat het } \\
\text { kan. } \\
\text { - Burgers een beetje laten betalen, en } \\
\text { beheerverantwoordelijkheid geven. }\end{array}$ & $\begin{array}{l}\text { - Jobrotatie. } \\
\text { - Te veel uitgaan van formele } \\
\text { beleidsdoelen. } \\
\text { - } \text { Te veel op een lange-termijndoel } \\
\text { afrekenen. } \\
\text { - Eigenaarschap overnemen. } \\
\text { - Te veel de resultaten in twijfel } \\
\text { trekken en daarmee nut en } \\
\text { noodzaak } \\
\text { - Stoppen met pilots wanneer het } \\
\text { niets oplevert of te duur is. }\end{array}$ \\
\hline Experimenteren & $\begin{array}{l}\text { Ieder experiment } \\
\text { genereert nieuwe } \\
\text { inzichten en ideeën } \\
\text { voor } \\
\text { vervolgexperimenten. } \\
\text { Experimenteren gaat } \\
\text { door, ook na } \\
\text { teleurstellingen. }\end{array}$ & $\begin{array}{l}\text { - Participeren in gezamenlijke } \\
\text { - } \text { experimenten. } \\
\text { zetten. Faciliteren kennisuitwisseling. } \\
\text { - Coöperaties oprichten en ondersteunen. } \\
\text { - Onderzoeksprogramma's zoals PTRN. } \\
\text { - Doorgaan na tegenvaller door een } \\
\text { andere locatie te zoeken. } \\
\text { - Buiten de lijntjes willen kleuren en het } \\
\text { lijntje even omleggen. } \\
\text { - Tender uitschrijven voor } \\
\text { coöperaties/initiatieven, met een reeks } \\
\text { aan duurzaamheid gerelateerde } \\
\text { vereisten, om creativiteit te stimuleren. } \\
\text { - In plaats van te vertellen 'hoe het } \\
\text { moet', partijen zelf laten leren, dingen } \\
\text { ervaren en uitproberen. }\end{array}$ & $\begin{array}{l}\text { - Alleen maar financieren van } \\
\text { voorspelbare pilots en } \\
\text { experimenten, zodat verrassingen } \\
\text { lastig worden. } \\
\text { - Ondersteunen van experimenten } \\
\text { voor de werving van financiële } \\
\text { middelen. } \\
\text { - Angst om af en toe een } \\
\text { doodlopende weg in te slaan. } \\
\text { - Te veel focus op nieuwe } \\
\text { experimenten ten koste van het } \\
\text { doorontwikkelen van wat er al is. } \\
\text { - Europese voorwaarden voor } \\
\text { subsidieregels (staatssteun) } \\
\text { - Begrenzen capaciteit organisaties } \\
\text { voor dit soort projecten. } \\
\text { - Strakke subsidieregels waarop } \\
\text { wordt geanticipeerd. } \\
\text { - Te veel tijd besteden aan het } \\
\text { ontvangen van delegaties en het } \\
\text { verzorgen van lezingen. } \\
\text { - Risicovolle experimenten die geld } \\
\text { kosten, werken niet voor } \\
\text { coöperaties. }\end{array}$ \\
\hline
\end{tabular}


Tabel 12.6 Bevorderende en beperkende overheidsinterventies (Termeer et al., 2019).

\begin{tabular}{|c|c|c|c|}
\hline $\begin{array}{l}\text { Aanjaag- } \\
\text { mechanismes }\end{array}$ & Beschrijving & Bevorderende (overheids)interventies & $\begin{array}{l}\text { Beperkende (overheids) } \\
\text { interventies }\end{array}$ \\
\hline $\begin{array}{l}\text { Logic of } \\
\text { attraction }\end{array}$ & $\begin{array}{l}\text { Zichtbaar succes en } \\
\text { commitment van } \\
\text { invloedrijke actoren } \\
\text { genereert middelen } \\
\text { (geld, mensen, } \\
\text { grond). }\end{array}$ & $\begin{array}{l}\text { - Initiatief publiekelijk waarderen. } \\
\text { - Met beloning/award positieve aandacht } \\
\text { creëren. } \\
\text { - Subsidies voor testen, pilots en demo's, } \\
\text { zodat initiatiefnemers aan andere } \\
\text { investeerders kunnen tonen dat ze iets } \\
\text { goeds in handen hebben. } \\
\text { - Vertrouwen geven (bijvoorbeeld door } \\
\text { subsidies), zodat andere partners ook } \\
\text { instappen. } \\
\text { - Aandacht in PTRN, en soms erbuiten } \\
\text { (Aan de slag met de omgevingswet, } \\
\text { Coöperatieve Samenleving, NL zorgt } \\
\text { voor Elkaar). Nog te weinig aandacht } \\
\text { vanuit overheden zelf. } \\
\text { - Gerealiseerde voorbeelden gebruiken } \\
\text { voor tenders waarbij duurzaamheid } \\
\text { belangrijk is, om te laten zien dat het } \\
\text { kan (zo hebben coöperaties ingezet op } \\
\text { Regiodeals). } \\
\text { - Met uitdagende tenders ook de niet } \\
\text { 'usual suspects' aantrekken. }\end{array}$ & $\begin{array}{l}\text { - Initiatieven alleen noemen als } \\
\text { smaakmaker voor eigen beleid } \\
\text { zonder dat initiatiefnemers daar } \\
\text { iets van merken of terugzien. } \\
\text { - Wel veel aandacht, maar niet veel } \\
\text { extra geld. } \\
\text { - Verminderen van het aantal } \\
\text { onderzoeks- en } \\
\text { samenwerkingsfondsen, } \\
\text { programma's waar coöperaties een } \\
\text { beroep op kunnen doen. }\end{array}$ \\
\hline Olievlekwerking & $\begin{array}{l}\text { Mensen volgen wat } \\
\text { andere mensen doen }\end{array}$ & $\begin{array}{l}\text { - Uitdragen initiatief. } \\
\text { - Faciliteren websites en open benchmark. } \\
\text { - Koplopers benoemen. } \\
\text { - Begrijpelijk en zichtbaar maken voor } \\
\text { burgers en bedrijven. } \\
\text { - Kleine successen in de etalage zetten. } \\
\text { - Verspreiden van kennis. }\end{array}$ & $\begin{array}{l}\text { - Te veel van bovenaf proberen te } \\
\text { beheersen. } \\
\text { - Laten voortbestaan van } \\
\text { beperkende wetgeving. } \\
\text { - (Onbewust) creëren van } \\
\text { contraproductieve concurrentie met } \\
\text { andere initiatieven. } \\
\text { - Alleen aandacht voor grote } \\
\text { icoonprojecten }\end{array}$ \\
\hline Verbinden & $\begin{array}{l}\text { Verbindingen leggen } \\
\text { tussen activiteiten } \\
\text { op andere } \\
\text { schaalniveaus of in } \\
\text { andere } \\
\text { beleidsdomeinen }\end{array}$ & $\begin{array}{l}\text { - Verbindingen mogelijk maken met } \\
\text { andere beleid (voor duurzaamheid). } \\
\text { Insteken van nieuwe thematiek bij lokale } \\
\text { netwerken van ondernemers, } \\
\text { maatschappelijk middenveld en } \\
\text { overheden rondom bestaande } \\
\text { vraagstukken. } \\
\text { - Opstart van veel projecten waarbij } \\
\text { PTRN-leden met elkaar in contact zijn } \\
\text { gekomen. } \\
\text { - Vaak verbindingen met energietransitie } \\
\text { als vliegwiel. } \\
\text { - Soms pogingen tot meekoppelen met } \\
\text { investeringen op andere terreinen. }\end{array}$ & $\begin{array}{l}\text { - } \text { Hokjesdenken resulterend in } \\
\text { - gelabeld geld en niet- passende } \\
\text { regels voor multifunctionele } \\
\text { initiatieven. } \\
\text { - Van bovenaf opleggen van } \\
\text { samenwerkingen. } \\
\text { - Focus vanuit overheden op } \\
\text { kerntaken. } \\
\text { - Sectoraal opgestelde targets en } \\
\text { uitgangspunten. } \\
\text { - Geld gekoppeld aan sectoren in } \\
\text { plaats van regionale integrale } \\
\text { duurzaamheid. } \\
\text { - Kostenefficiëntie nog te vaak als } \\
\text { doorslaggevend criterium. }\end{array}$ \\
\hline Robuustheid & $\begin{array}{l}\text { Massa creëren zodat } \\
\text { een proces } \\
\text { onomkeerbaar } \\
\text { wordt. } \\
\text { Internaliseren in } \\
\text { opvattingen, } \\
\text { structuren en gedrag }\end{array}$ & $\begin{array}{l}\text { - Langdurige betrokkenheid bij initiatief in } \\
\text { goede en slechte tijden. } \\
\text { - Lokale betrokkenheid bevordert roots in } \\
\text { lokale gemeenschap. }\end{array}$ & $\begin{array}{l}\text { - Gebrek aan continuïteit in } \\
\text { ondersteuning } \\
\text { (subsidies/financiering). } \\
\text { - Er te veel vanuit gaan dat bekende } \\
\text { initiatieven zichzelf kunnen } \\
\text { bedruipen. }\end{array}$ \\
\hline
\end{tabular}

In tabel 12.7 geven wij aan wat mogelijk ideeën zijn voor bevorderende interventies vanuit de PTRN om de small wins verder te verspreiden, te verbreden en te verdiepen. 
Tabel 12.7 Bevorderende interventies door PTRN?

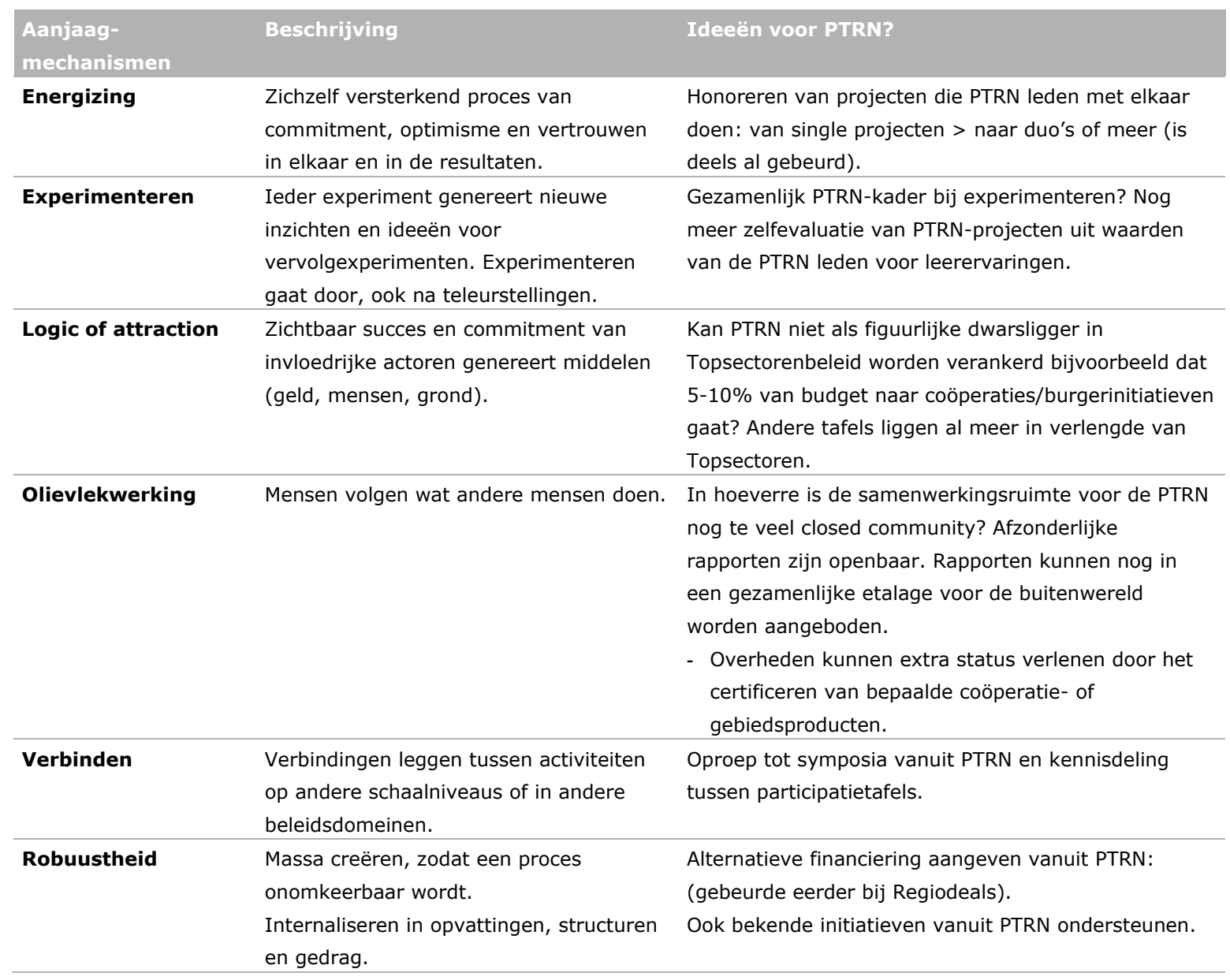

Uit de handelingsperspectieven voor de PTRN kan worden opgemaakt dat:

- de handelingsperspectieven door de PTRN en de overheden nog niet volledig zijn benut om het gedachtegoed van projecten te verspreiden, te verbreden en te verdiepen;

- de borging van de functies die de PTRN vervult, niet zijn geborgd na 2020;

- Ook kan uit de handelingsperspectieven worden opgemaakt dat die borging niet automatisch vanzelf zal gaan. Als een voortzetting van de PTRN er niet in zit, zullen de taken van de PTRN zo veel mogelijk elders geborgd dienen te worden om regionale netwerken te kunnen ondersteunen. 


\title{
13 Conclusies en aanbevelingen
}

\author{
Conclusies \\ Er zijn negen projecten geselecteerd, waar potentiële small wins aan het ontstaan en soms ook al aan \\ het accumuleren zijn, te weten: Food Council, Right to challenge, CoöperatieAuto, Tafeldemocratie, \\ Toogdialoog, Reflexieve monitoring en vitaliteitsdiagnose, Gebiedscoöperatie, Oefenrechtbank en \\ Vreedzaam leren en doen. Deze projecten laten zich moeilijk vergelijken en evalueren omdat ze \\ verschillende theoretische invalshoeken hanteren, wat vanuit een small wins-benadering geen \\ probleem is. Ze kennen stuk voor stuk mooie ambities en ontwikkelen innovatieve concepten. Deze \\ aanzetten zien er veelbelovend uit en neigen tot small wins, maar het is vaak nog te vroeg is om vast \\ te stellen of de projecten daadwerkelijk tot de voorgestane institutionele veranderingen leiden. Door \\ een combinatie van missie, energie, doorzettingsvermogen en gunfactor zijn veel barrières \\ overwonnen, maar er moeten er ook nog veel geslecht worden, zoals vastzittende overtuigingen, \\ gebrek aan (continuïteit in) financiering of langs elkaar werkende overheden.
}

Nagegaan is welke handelingsperspectieven er voor de PTRN en de deelnemers zijn om projecten verder te brengen: te verspreiden, te verbreden en te verdiepen.

Uit de handelingsperspectieven voor de PTRN kan worden opgemaakt dat:

- de handelingsperspectieven door de PTRN en de overheden nog niet volledig zijn benut om het gedachtegoed van projecten te verspreiden, te verbreden en te verdiepen;

- de borging van de functies die de PTRN vervult, niet zijn geborgd na 2020;

- ook kan uit de handelingsperspectieven worden opgemaakt dat die borging niet automatisch vanzelf zal gaan. Als een voortzetting van de PTRN er niet in zit, zullen de taken van de PTRN zo veel mogelijk elders geborgd dienen te worden om regionale netwerken te kunnen ondersteunen.

De hoofdconclusie is dat het verspreiden, verbreden en verdiepen deels is gebeurd, maar dat er op papier nog veel meer ambities zijn. De mogelijke ondersteunende functies van de PTRN aan projecten hiervoor zijn nog niet ten volle benut en niet structureel geborgd. Dit achtte deelnemende projecten wel noodzakelijk om transities in gang te zetten (kiemen) en verder te brengen. De PTRN zou de small wins graag benutten om transities te versnellen. De PTRN kan hiervoor een grotere massa creëren, dus vooral inzetten op verspreiden. Ook kan ingezet worden op doorwerking van de bevindingen uit de PTRN richting rijksbeleid en provinciaal beleid, om zo het gedachtegoed uit de casussen verder te verspreiden. Het rapport biedt enkele aangrijpingspunten om transities te versnellen, maar transities zijn niet maakbaar en kosten tijd. Om veranderingen te laten indalen, zijn er ook culturele en institutionele veranderingen nodig die zich niet gemakkelijk laten versnellen. Small wins zijn hiervoor de eerste aanzet.

\section{Aanbevelingen}

Het beste om transities te laten kiemen en verder te brengen, is om de PTRN te laten voortbestaan, dan wel de functies die de PTRN vervulde (bijvoorbeeld kennis- en ervaringsuitwisseling, financiële ondersteuning) elders te beleggen, opdat initiatiefnemers van vernieuwende projecten die aanzetten tot institutionele verandering, ook in de nabije toekomst een steun in de rug ervaren. Wanneer projecten in regionale netwerken al een beetje gedragen worden vanuit de PTRN of overheden, is dit reden voor initiatiefnemers om de moed niet op te geven. Uiteraard blijft er dan voor initiatiefnemers van projecten nog steeds veel energie, tijd en gedrevenheid nodig om ambities om te zetten in concrete resultaten en de initiële small wins te verspreiden, te verbreden en te verdiepen. 


\section{Literatuur}

Dewulf, A., Termeer, C., Breeman, G., and Werkman, R. 2010. Governance capabilities for achieving small wins in wicked policy domains. In 17th Annual MOPAN Conference 2010.

Haas, W. de, M. Pleijte, C.C. de Lauwere, L.J.W. van Hoof, 2020. Now is the time to get this done? White paper. Wageningen: WUR/WENR.

An agenda for Governance in the Transition towards a Circular Agriculture.

Lindblom, C. (1959) The Science of 'Muddling Through'. Public Administration Review. 19(2):79-88.

Termeer, C.J.A.M. (2018). Meer dan klein bier! LIB als continue aanjager van betekenisvolle verandering,https://www.wur.nl/nl/nieuws/LIB-als-continue-aanjager-van-betekenisvolleverandering.htm

Termeer, C.J.A.M. en Dewulf, A. (2017) Mogelijkheden van de 'small wins' aanpak voor de transitieopgaven van het Ministerie van Infrastructuur en Waterstaat. https://www.wur.nl/en/newsarticle/Rapport-smallwins-aanpak-voor-de-transitie-opgaven.htm

Termeer, C.J.A.M. and Dewulf, A. (2018). A small wins framework to overcome the evaluation paradox of governing wicked problems. Policy and Society. https://doi.org/10.1080/14494035.2018.1497933

Termeer, C.J.A.M., T.A.P. Metze en D. Wiegant, 2019. Een small wins raamwerk voor transitiemanagement door het ministerie van Infrastructuur en Waterstaat. Wageningen: Wageningen University.

Termeer, C.J.A.M., 2019. Het bewerkstellingen van een transitie naar kringlooplandbouw. Notitie opgesteld op verzoek van de Tweede Kamer Commissie LNV.

Termeer, C.J.A.M., 2020. Powerpointpresentatie. Participatietafel Regionale Netwerken. The Next steps. Kick off bijeenkomst op 3 februari 2020 te Utrecht.

Termeer, T.A.P. Metze, 2019. More than peanuts: Transformation towards a circular economy through a small-wins governance framework. In: Journal of Cleaner Production, vol 240. 10 Dec 2019.

Weick, K.E. (1984) Small Wins: Redefining the Scale of Social Problems. American Psychologist. 39(1): 40-49.

Weick, K. (2001). Making sense of the organization. Oxford: Blackwell.

Website:

https://www.duurzaamdoor.nl/over-duurzaamdoor

\section{Literatuur en websites per casus}

\section{Casus 1: Oprichting Food Council Metropolitan Regio Amsterdam}

Valk, A. van der, J. Spangenberg en T. Jones, 2018. Een voedselraad voor de metropoolregio Amsterdam: Food Council MRA. Eindrapport voor het consortiumproject 'Food Council MRA' vanuit de Participatietafel Regionale Duurzaamheidsnetwerken.

\section{Websites:}

https://vanamsterdamsebodem.nl/initiatieven/food-council-metropool-regio-amsterdam/

https://www.duurzaambedrijfsleven.nl/futurefood/26153/een-nieuwe-integrale-benadering-vanregionaal-voedselbeleid-in-amsterdam

\section{Casus 2: Right to challenge voor zorg en welzijn in stadsdorp Elsrijk te Amstelveen} Heijden, J. van der en J. Klapwijk, 2020. Stadsdorp Elsrijk komt langszij. Naar een andere trias politica. Verslag voor Duurzaam Door, februari 2020

Website:

http://www.stadsdorpelsrijk.nl/ 


\title{
Casus 3: CoöperatieAuto (Culemborg)
}

Verschuur, G., J. de Cock en T. Tekelenburg, 2019. CoöperatieAuto. Handvat E-deelauto's voor energiecoöperaties. In; emovia, startpunt voor elektrisch rijden.

Website:

https://www.cooperatieauto.nl/

\section{Casus 4: Tafeldemocratie van de Vereniging Noorden Duurzaam in 3 pilots}

Website:

https://www.noordenduurzaam.nl/

\author{
Casus 5: Toogdialoog van Organisatie Lijnspel om Flitscoöperatie (energie) op te richten in \\ Heerlen-Centrum \\ https://www.1limburg.nl/heerlen-krijgt-energiecooperatie-5000-zonnepanelen-stad \\ https://heerlen.nieuws.nl/nieuws/73378/5000-zonnepanelen-op-daken-heerlen/ \\ https://www.limburger.nl/cnt/dmf20191024_00129344
}

Casus 6: Reflexieve monitoring coalitie Groen Verbindt in Alblasserwaard-Vijfheerenlanden Sol, J. en J. Hinssen (2018). Naar een kennisinfrastructuur voor maatschappelijk leren op regionale schaal. Rapportage inventarisatie van de ondersteuningsbehoefte van change agents in de Provincie Zuid Holland. Casus Groen Verbindt Alblasserwaard-Vijfheerenlanden, Wageningen, Venlo.

Sol, J. (2020). Reflexief lerende gebiedsnetwerken en change agents A5H. Vervolg pilot Groen Verbindt Alblasserwaard-Vijfheerenlanden. Wageningen. Verslag voor PTRN/DuurzaamDoor.

\section{Casus 7: Oprichting Coöperatie Bommelerwaar}

Bekkum, O. van, 2019. Kwartiermaken in de Rijnlands-Coöperatieve Gebiedseconomie. Rapportage opgeleverd aan de Participatietafel Regionale Netwerken (PTRN) binnen het DuurzaamDoorprogramma van de Rijksdienst voor Ondernemend Nederland (RVO). Versiedatum: 10 december 2019. (rapportnummer: DD2201950)

Ton \& Van den Broeke notarissen, 2016. Statuten Coöperatie Bommelerwaar.

\section{Casus 8: Oefenrechtbank Notter Zuna in Wierden}

Ravenhorst, E., E. Spronck en O. van Bekkum (allen Coöperatieve Samenleving, 2018. Het Rijnlands Gebiedsarrangement. RVO Opdracht JLE2017119, 22 mei 2018. Bijlage 2: Vonnis oefenrechtbank Notter Zuna.

Website:

https://www.duurzaamdoor.nl/sites/default/files/2019-

03/20180619\%20DCS\%20Gebiedsarrangement\%20def.pdf

http://www.notterzuna.nl/profielen/cooperatie-notter-zuna/

https://conz.nl/

Casus 9: project 'Vreedzaam leren en doen' van Gebiedscoöperatie Rivierenland

Gebiedscoöperatie Rivierenland, 2018. Eindrapportage voor project "Vreedzaam leren en doen" van de Gebiedscoöperatie Rivierenland, 27 juni 2018.

Gebiedscoöperatie Rivierenland, 2020. Overzicht duurzame burgerinitiatieven binnen het collectief netwerk van de Gebiedscoöperatie Rivierenland.

Teisman, G., 2019. Energietransitie gediend bij slim georganiseerde regionale tussenruimtes.

Websites:

https://www.resrivierenland.nl/wie-maakt-de-res/

https://www.overheidvannu.nl/

https://www.regionale-energiestrategie.nl/default.aspx

https://www.resrivierenland.nl/regionale-energiestrategie-bijeenkomst-samenwerkingsagenda/ https://www.resrivierenland.nl/wp-content/uploads/Notitie-uitgangspunten-RES-Rivierenland.pdf https://www.fruitdelta.nl/regiodeal/ 


\section{Bijlage 1 Vragenlijst}

Centrale vragen

1. In hoeverre en op welke manier kan de Small Wins-aanpak helpen om de resultaten van DuurzaamDoor beter te identificeren en zichtbaar te maken?

2. Welke handelingsperspectieven biedt het toepassen van de Small Wins-aanpak voor het verder brengen van de transitieambities van DuurzaamDoor?

Ad 1)

In hoeverre zijn de praktijken te kwalificeren als Small Wins? Daarvoor gebruiken we de volgende criteria: Tastbare resultaten voor directbetrokkenen.

- Betekenisvolle stap op weg naar systeemverandering; transitie ambitie

- Diepgaande verandering/omdenken

- Wrijving ontmoet en barrières voorkomen

- Verbinding technische en sociale verandering

- Plek met energie

\section{Vragen DEEL 1: identificeren van de small wins}

1. Wat is het tastbare resultaat van deze praktijk en voor wie is dat zichtbaar?

2. In hoeverre is het een kleine stap in de richting van de duurzaamheidambities en waarom?

3. Welke omslag in denken is gerealiseerd en wat is het verhaal daarachter?

4. Welke spanningen met bestaande overtuigingen, regels, technologie, middelen en financiële modellen zijn ze tegengekomen, welke barrières hebben ze overwonnen en hoe hebben ze dat gedaan?

4b. Heeft de PTRN geholpen om barrières te overwinnen?

5. Welke (overheids)interventies hebben bedoeld of onbedoeld geholpen?

5b. Welke rol speelden gemeenten of provincies bij jouw initiatief?

5c. Is sprake geweest van een veranderende rol van provincies of gemeenten?

6. Hoe zijn sociale en technische innovaties met elkaar verbonden?

7. Is het een plek met energie om verder te experimenteren en te leren?

8. Is sprake van enkele small wins of van een serie van small wins? [bij de deelauto zijn ze in series aan het denken]

Vragen Deel twee: vooruitkijken, mogelijkheden voor verbreden, verdiepen en verspreiden

9. Indien zich in de ontwikkelfase van je initiatief nog geen small wins voordeden, hoe kan het initiatief nog een small win worden? Wat is daarvoor nodig?

10. Hoe zijn de small wins verder te brengen?

- Verspreiden: innovatie opschalen of uitrollen door deze ook elders toe te passen.

11. Welke mogelijkheden zijn er tot opschaling van successen/small wins van jouw initiatief? Wat is daarvoor nodig? Welke ervaringen kun je meenemen uit eerste small wins? Welke barrières verwacht je dat er groter zullen worden?

- Verbreden: innovatie toepassen op andere terreinen en verbinden met andere terreinen.

12. Welke mogelijkheden zijn er tot verbreding van successen/small wins van jouw initiatief? Wat is daarvoor nodig? Welke ervaringen kun je meenemen uit eerste small wins? Welke barrières verwacht je dat er groter zullen worden?

- Verdiepen: innovatie nog radicaler maken.

13. Welke mogelijkheden zijn er tot verdieping van successen/small wins van jouw initiatief? Wat is daarvoor nodig? Welke ervaringen kun je meenemen uit eerste small wins? Welke barrières verwacht je dat er groter zullen worden?

14. Alles overziend: tot welke concrete handelingsperspectieven kan dat leiden voor jullie initiatief en voor PTRN?

15. Wat was voor jou de meerwaarde van de PTRN? 


\section{Bijlage 2 Interviews en bijeenkomsten}

\section{Interviews}

- Arnold van der Valk, Food Council Metropolitan Regio Amsterdam, 12 maart 2020.

- Jurgen van der Heijden, Right to challenge voor zorg en welzijn in stadsdorp Elsrijk te Amstelveen, 17 maart 2020.

- Jan de Cock, Coöperatie Auto te Culemborg, 17 maart 2020.

- Peter Bootsma, Tafeldemocratie van de Vereniging Noorden Duurzaam in 3 pilots, 17 maart 2020.

- Onno van Bekkum, Coöperatie Bommelerwaar, 25 maart 2020.

- Leo Crombach, Toogdialoog van Organisatie Lijnspel om Flitscoöperatie (energie) in Heerlencentrum op te richten, 19 maart 2020.

- Jules Hinssen, Reflexieve monitoring en vitaliteitsdiagnose landschapstafel Groen verbindt in Alblasserwaard-Vijfheerenlanden, 19 maart 2020.

- Jifke Sol, Reflexieve monitoring en vitaliteitsdiagnose landschapstafel Groen verbindt in Alblasserwaard-Vijfheerenlanden, 20 maart 2020.

- Eduard Ravenhorst, Oefenrechtbank Notter Zuna, 25 maart 2020.

\section{Workshops/lezingen}

- Participatietafel Regionale Netwerken. Kick off bijeenkomst. Karel de V, te Utrecht, 03-02-2020.

- Participatietafel Regionale Netwerken. The next steps. Digitale bijeenkomst. 15-04-2020. 
Wageningen Environmental Research Postbus 47

6700 AA Wageningen

T 0317480700

www.wur.nl/environmental-research

Wageningen Environmental Research Rapport 3039

ISSN 1566-7197
De missie van Wageningen University \& Research is 'To explore the potential of nature to improve the quality of life'. Binnen Wageningen University \& Research bundelen Wageningen University en gespecialiseerde onderzoeksinstituten van Stichting Wageningen Research hun krachten om bij te dragen aan de oplossing van belangrijke vragen in het domein van gezonde voeding en leefomgeving. Met ongeveer 30 vestigingen, 6.500 medewerkers ( $5.500 \mathrm{fte}$ ) en 12.500 studenten behoort Wageningen University \& Research wereldwijd tot de aansprekende kennisinstellingen binnen haar domein. De integrale benadering van de vraagstukken en de samenwerking tussen verschillende disciplines vormen het hart van de unieke Wageningen aanpak. 


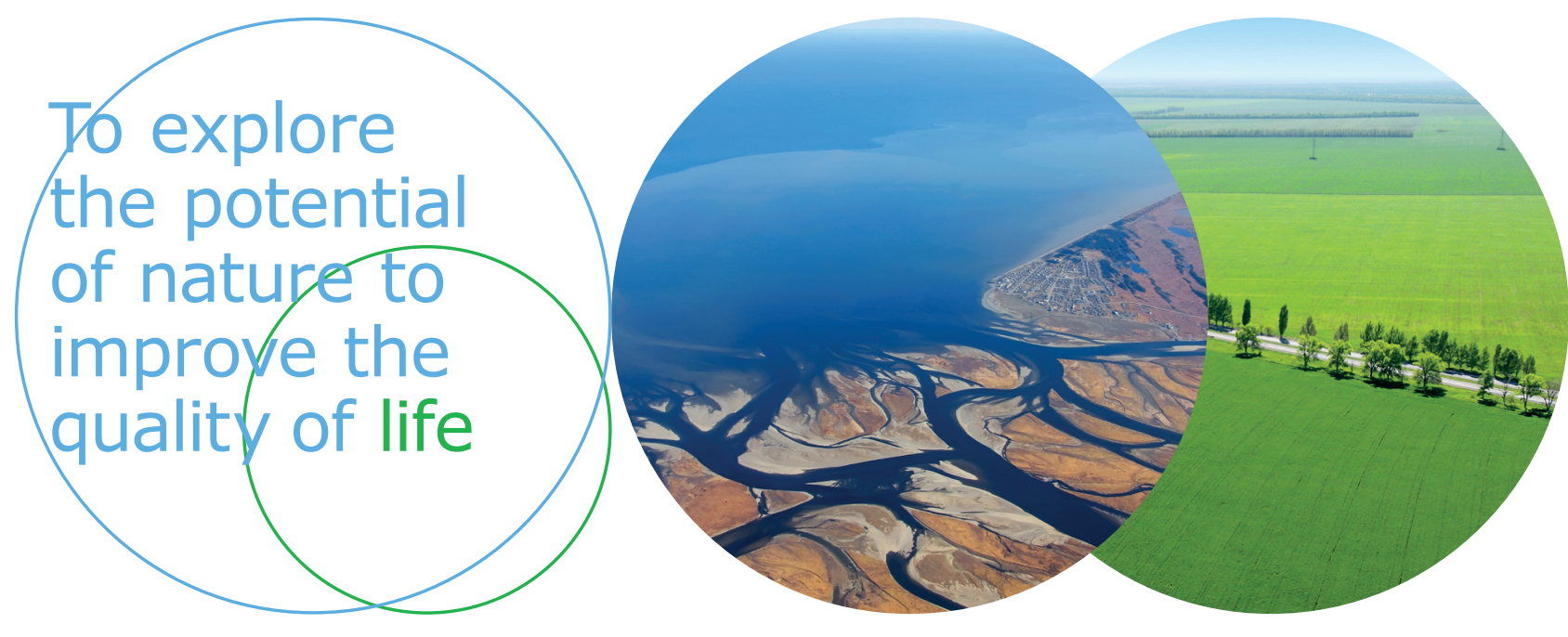

Wageningen Environmental Research Postbus 47

$6700 \mathrm{AB}$ Wageningen

T 317480700

www.wur.nl/environmental-research

Rapport 3039

ISSN 1566-7197
De missie van Wageningen University \& Research is 'To explore the potential of nature to improve the quality of life'. Binnen Wageningen University \& Research bundelen Wageningen University en gespecialiseerde onderzoeksinstituten van Stichting Wageningen Research hun krachten om bij te dragen aan de oplossing van belangrijke vragen in het domein van gezonde voeding en leefomgeving. Met ongeveer 30 vestigingen, 6.500 medewerkers ( $5.000 \mathrm{fte}$ ) en 12.500 studenten behoort Wageningen University \& Research wereldwijd tot de aansprekende kennisinstellingen binnen haar domein. De integrale benadering van de vraagstukken en de samenwerking tussen verschillende disciplines vormen het hart van de unieke Wageningen aanpak. 